\title{
Estimation of the Recharge Area
}

Contributing Water to a Pumped Well In a Glacial-Drift, River-Valley Aquifer

United States

Geological

Survey

Water-Supply

Paper 2338

Prepared in

cooperation

with the

Rhode Island

Department of

Environmental

Management

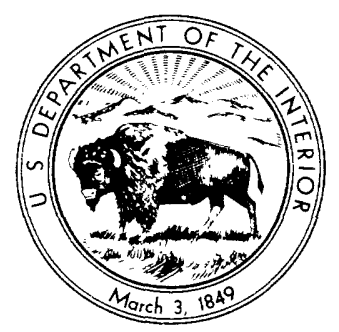




\section{AVAILABILITY OF BOOKS AND MAPS OF THE U.S. GEOLOGICAL SURVEY}

Instructions on ordering publications of the U.S. Geological Survey, along with prices of the last offerings, are given in the current-year issues of the monthly catalog "New Publications of the U.S. Geological Survey." Prices of available U.S. Geological Survey publications released prior to the current year are listed in the most recent annual "Price and Availability List." Publications that are listed in various U.S. Geological Survey catalogs (see back inside cover) but not listed in the most recent annual "Price and Availability List" are no longer available.

Prices of reports released to the open files are given in the listing "U.S. Geological Survey Open-File Reports," updated monthly, which is for sale in microfiche from the U.S. Geological Survey, Books and Open-File Reports Section, Federal Center, Box 25425, Denver, CO 80225. Reports released through the NTIS may be obtained by writing to the National Technical Information Service, U.S. Department of Commerce, Springfield, VA 22161; please include NTIS report number with inquiry.

Order U.S. Geological Survey publications by mail or over the counter from the offices given below.

\section{BY MAIL}

\section{Books}

Professional Papers, Bulletins, Water-Supply Papers. Techniques of Water-Resources Investigations, Circulars, publications of general interest (such as leaflets, pamphlets, booklets), single copies of Earthquakes \& Volcanoes, Preliminary Determination of Epicenters, and some miscellaneous reports, including some of the foregoing series that have gone out of print at the Superintendent of Documents, are obtainable by mail from

\section{U.S. Geological Survey, Books and Open-File Reports Federal Center, Box 25425 Denver, CO 80225}

Subscriptions to periodicals (Earthquakes \& Volcanoes and Preliminary Determination of Epicenters) can be obtained ONLY from the

\section{Superintendent of Documents Government Printing Office Washington, D.C. 20402}

(Check or money order must be payable to Superintendent of Documents.)

\section{Maps}

For maps, address mail orders to

\section{U.S. Geological Survey, Map Distribution Federal Center, Box 25286 \\ Denver, CO 80225}

Residents of Alaska may order maps from

\section{Alaska Distribution Section, U.S. Geological Survey}

New Federal Building - Box 12

101 Twelfth Ave., Fairbanks, AK 99701

\section{OVER THE COUNTER}

\section{Books}

Books of the U.S. Geological Survey are available over the counter at the following U.S. Geological Survey Public Inquiries Offices, all of which are authorized agents of the Superintendent of Documents:

- WASHINGTON, D.C.-Main Interior Bldg., 2600 corridor, 18 th and C Sts., NW.

- DENVER, Colorado-Federal Bldg., Rm. 169, 1961 Stout St.

- LOS ANGELES, California-Federal Bldg., Rm. 7638,300 N. Los Angeles St.

- MENLO PARK, California-Bldg. 3 (Stop 533), Rm. 3128, 345 Middlefield Rd.

- RESTON, Virginia-503 National Center, Rm. 1C402, 12201 Sunrise Valley Dr.

- SALT LAKE CITY, Utah-Federal BIdg., Rm. 8105, 125 South State St.

- SAN FRANCISCO, California-Customhouse, Rm. 504, 555 Battery St.

- SPOKANE, Washington-U.S. Courthouse, Rm. 678, West 920 Riverside Ave.

- ANCHORAGE, Alaska-Rm. 101, 4230 UniversityDr.

- ANCHORAGE, Alaska-Federal Bldg, Rm. E-146, 701 C St.

\section{Maps}

Maps may be purchased over the counter at the U.S. Geological Survey offices where books are sold (all addresses in above list) and at the following U.S. Geological Survey offices:

- ROLLA, Missouri-1400 Independence Rd.

- DENVER, Colorado-Map Distribution, Bldg. 810, Federal Center

- FAIRBANKS, Alaska-New Federal Bldg., 101 Twelfth Ave. 
Estimation of the Recharge Area

Contributing Water to a Pumped Well

In a Glacial-Drift, River-Valley Aquifer

\section{BY DANIEL J. MORRISSEY}

Prepared in cooperation with the

Rhode Island Department of

Environmental Management 


\title{
DEPARTMENT OF THE INTERIOR
}

MANUEL LUJAN, Jr., Secretary

\author{
U.S. GEOLOGICAL SURVEY \\ Dallas L. Peck, Director
}

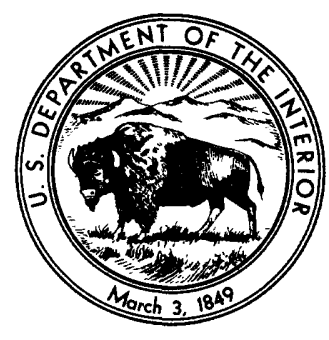

Any use of trade, product, or firm names in this publication is for descriptive purposes only and does not imply endorsement by the U.S. Government

UNITED STATES GOVERNMENT PRINTING OFFICE: 1989

For sale by the

Books and Open-File Reports Section, U.S. Geological Survey,

Federal Center, Box 25425,

Denver, CO 80225

Library of Congress Cataloging in Publication Data

Morrissey, Daniel J.

Estimation of the recharge area contributing water to a pumped well in a glacial-drift, river-valley aquifer.

(U.S. Geological Survey water-supply paper ; 2338)

"Prepared in cooperation with the Rhode Island Department of Environmental Management."

Bibliography: $p$

Supt. of Docs. no. : I 19.13:2338

1. Water, Underground-New England-Mathematical models. 2. AquifersNew England-Mathematical models. 3. Water, Underground-New England-Quality-Mathematical models. I. Title. II. Series.

$\begin{array}{llll}\text { GB1016.3.M67 } & 1989 & 627^{\prime} .56 & 88-600009\end{array}$ 


\title{
CONTENTS
}

\author{
Abstract 1 \\ Introduction $\mathbf{2}$ \\ Purpose and Scope 2 \\ Previous Investigations 2 \\ Acknowledgments $\mathbf{3}$
}

Geohydrology of Glacial-Drift, River-Valley Aquifer Systems $\mathbf{3}$

Physical Properties 3

Hydraulic Properties 3

Recharge $\mathbf{3}$

Discharge 4

Sources of Water in Wells-A Review 5

The Concept of Contributing Area 7

Definitions 7

Factors Affecting the Contributing Area of a Well 9

Selected Methods for Estimating Contributing Area 9

Analytical Model 9

Two-Dimensional Numerical Model $\mathbf{1 2}$

Three-Dimensional Numerical Model 12

Contributing Area Analysis and Sensitivity Testing 13

A Hypothetical Glacial-Drift, River-Valley Aquifer System 13

Analytical-Model Analysis $\mathbf{1 4}$

Procedure for Contributing-Area Estimation 14

Application 14

Two-Dimensional Numerical-Model Analysis 15

Procedure for Contributing-Area Estimation 19

Application and Sensitivity Testing 19

Well Discharge 19

Aquifer Recharge 22

Streambed Permeability 22

Aquifer Hydraulic Conductivity $\mathbf{2 4}$

Proximity of the Well to a River 27

Transient Simulation 27

Three-Dimensional Numerical-Model Analysis 29

Application and Sensitivity Testing 29

Summary of the Effects of Selected Hydrogeologic Factors $\mathbf{3 3}$

Comparison of Methods and Guidelines for Estimating Contributing Areas 36

Summary and Conclusions $\mathbf{3 9}$

References Cited $\mathbf{4 0}$

\section{FIGURES}

1. Block diagram showing the generalized geologic setting for glacial-drift, river-valley aquifers 4 
2. Block diagram showing recharge-discharge relations and flow patterns in glacial-drift, river-valley aquifers $\mathbf{5}$

3-5. Diagrams showing ground-water flow at various stages of aquifer development:

3. Natural equilibrium conditions before pumping 6

4. Early pumping conditions 6

5. Late pumping conditions at equilibrium 6

6. Diagram of a pumping well showing a cross-sectional view of the cone of depression and a plan view of the area of influence 7

7. Diagram of a pumping well showing a cross-sectional view of the zone of contribution and a plan view of the contributing area $\mathbf{8}$

8. Block diagram showing the geohydrologic features of the hypothetical aquifer used in figure 9 to illustrate the difference between the area of influence and the contributing area of a pumped well $\mathbf{8}$

9. Maps of the hypothetical aquifer, illustrated in figure 8 , showing prepumping flow net, steady-state drawdowns and the area of influence of a pumped well, and flow net and contributing area for pumping conditions $\mathbf{1 0}$

10-12. Diagrams showing:

10. $A$, Head distribution for a natural-flow system; $B$, Drawdowns caused by a pumping stress; and $C$, Head distribution resulting from superposition of $A$ and $B \quad \mathbf{1 1}$

11. The geohydrologic features of the hypothetical stratified-drift, rivervalley aquifer addressed in the model analyses 13

12. An idealized version of the aquifer for analysis with an analytical model using a line-source river boundary 15

13. Maps of the idealized aquifer showing, $A$, Prepumping water-table altitudes; $B$, Drawdowns computed by using the analytical model; and $C$, Water-table altitudes and contributing area resulting from superposition of $A$ and $B$ for the line-source river-boundary condition 16

14. Finite-difference grid used for the two-dimensional numerical-model analyses shown in plan and cross-sectional views 17

15-17. Maps showing:

15. Contributing areas for a well pumping 0.25 million gallons per day in a river-valley aquifer $\mathbf{1 8}$

16. Average steady-state water-table altitudes, without pumping, computed by using the two-dimensional numerical model 19

17. Water-table altitudes and contributing areas of a well pumped at $0.5,1.0$, and 2.0 million gallons per day 20

18. Graphs showing sizes of contributing areas and sources of water pumped from the well as a function of well discharge $\mathbf{2 1}$

19. Maps showing water-table altitudes and contributing areas of a well pumped at 1.0 million gallons per day for 0.5 times average, average, and 1.5 times average recharge 23

20. Graphs showing sizes of contributing areas and sources of water pumped from the well as a function of recharge rate $\mathbf{2 4}$

21. Maps showing water-table configuration and contributing area of a well pumped at 1.0 million gallons per day after 30,90 , and 180 days of drought 25

22. Maps showing water-table altitudes and contributing areas of a well pumped at 1.0 million gallons per day and having streambed coefficients $\left(k^{\prime} / b^{\prime}\right)$ of $0.1,1.0$, and 10.026

23. Graphs showing sizes of contributing areas and sources of water pumped from the well as a function of streambed coefficient $\left(k^{\prime} / b^{\prime}\right)$ 
24. Maps showing water-table altitudes and contributing areas of a well pumped at 1.0 million gallons per day for 0.3 times average, average, and 3.0 times average hydraulic conductivity $\mathbf{2 8}$

25. Graphs showing sizes of contributing areas and sources of water pumped from the well as a function of aquifer hydraulic conductivity $\mathbf{2 9}$

26. Maps showing water-table altitudes and contributing areas for a well pumped at 0.5 million gallons per day located 200,600 , and $1,400 \mathrm{ft}$ from a source of induced infiltration $\mathbf{3 0}$

27. Graph showing sources of water pumped by a well, under average conditions, as a function of time 31

28. Finite-difference grid used for the three-dimensional numerical-model analysis shown in plan and cross-sectional views $\mathbf{3 2}$

29. Map showing steady-state nonpumping water-table altitudes computed by using the three-dimensional numerical model $\mathbf{3 3}$

30. Map showing the zone of contribution for a well, pumped at 1.0 million gallons per day, as determined by using the three-dimensional numerical model 35

31. Guide for selecting a hydraulic method of analysis to estimate the contributing area of a well in an unconfined stratified-drift, river-valley aquifer $\mathbf{3 7}$

\section{TABLES}

1. Factors affecting contributing area 9

2. Average annual water budget for the hypothetical aquifer computed by using the two-dimensional numerical model 18

3. Summary of ground-water-protection areas for municipal-supply wells in New England $\mathbf{2 1}$

4. Total contributing area size as a function of well penetration and $K_{\mathrm{h}} / K_{\mathrm{v}} \quad 32$

5. Summary of the effects of variations in selected geohydrologic factors on the size of the contributing area of a well in a hypothetical aquifer 34

\section{METRIC CONVERSION FACTORS}

For readers who wish to convert measurements from the inch-pound system of units to the metric system of units, the conversion factors are listed below:

\begin{tabular}{rll}
\hline Multiply inch-pound unit & By & To obtain metric unit \\
\hline inch (in) & 25.4 & millimeter $(\mathrm{mm})$ \\
inch per year (in/yr) & 25.4 & millimeter per year $(\mathrm{mm} / \mathrm{yr})$ \\
foot $(\mathrm{ft})$ & .3048 & meter $(\mathrm{m})$ \\
mile $(\mathrm{mi})$ & 1.609 & kilometer $(\mathrm{km})$ \\
square mile $\left(\mathrm{mi}^{2}\right)$ & 2.59 & square kilometer $\left(\mathrm{km}^{2}\right)$ \\
square foot per day $\left(\mathrm{ft}^{2} / \mathrm{d}\right)$ & .0929 & square meter per day $\left(\mathrm{m}^{2} / \mathrm{d}\right)$ \\
cubic foot per second $\left(\mathrm{ft}^{3} / \mathrm{s}\right)$ & .02832 & cubic meter per second $\left(\mathrm{m}^{3} / \mathrm{s}\right)$ \\
gallon per minute $(\mathrm{gal} / \mathrm{min})$ & .06309 & liter per second $(\mathrm{L} / \mathrm{s})$ \\
million gallons per day $(\mathrm{Mgal} / \mathrm{d})$ & .04381 & cubic meter per second $\left(\mathrm{m}^{3} / \mathrm{s}\right)$ \\
foot per year per square & .7894 & meter per year per square \\
mile $\left[(\mathrm{ft} / \mathrm{yr}) / \mathrm{mi}^{2}\right]$ & & kilometer $\left[(\mathrm{m} / \mathrm{yr}) / \mathrm{km}^{2}\right]$ \\
\hline
\end{tabular}

\section{ALTITUDE DATUM}

National Geodetic Vertical Datum of 1929 (NGVD of 1929): A geodetic datum derived from a general adjustment of the first-order level nets of both the United States and Canada; formerly called Sea Level Datum of 1929. 


\title{
Estimation of the Recharge Area Contributing Water To a Pumped Well In a Glacial-Drift, River-Valley Aquifer
}

\author{
By Daniel J. Morrissey
}

\begin{abstract}
The highly permeable, unconfined, glacial-drift aquifers that occupy most New England river valleys constitute the principal source of drinking water for many of the communities that obtain part or all of their public water supply from ground water. Recent events have shown that these aquifers are highly susceptible to contamination that results from a number of sources, such as seepage from wastewater lagoons, leaking petroleum-product storage tanks, and road salting.

To protect the quality of water pumped from supply wells in these aquifers, it is necessary to ensure that potentially harmful contaminants do not enter the ground in the area that contributes water to the well. A high degree of protection can be achieved through the application of appropriate land-use controls within the contributing area. However, the contributing areas for most supply wells are not known.
\end{abstract}

This report describes the factors that affect the size and shape of contributing areas to public supply wells and evaluates several methods that may be used to delineate contributing areas of wells in glacial-drift, rivervalley aquifers. Analytical, twodimensional numerical, and threedimensional numerical models were used to delineate contributing areas. These methods of analysis were compared by applying them to a hypothetical aquifer having the dimensions and geometry of a typical glacial-drift, river-valley aquifer. In the model analyses, factors that control the size and shape of a contributing area were varied over ranges of values common to glacial-drift aquifers in New England. The controlling factors include the rate of well discharge, rate of recharge to the aquifer from precipitation and from adjacent till and bedrock uplands, distance of a pumping well from a stream or other potential source of induced recharge, degree of hydraulic connection of the aquifer with a stream, horizontal hydraulic conductivity of the aquifer, ratio of horizontal to vertical hydraulic conductivity, and degree of well penetration.

Analytical methods proved easiest to apply but gave results that are considered to be less accurate than those obtainable by means of numerical-model analysis. Numerical models have the capability to more closely reflect the variable geohydrologic conditions typical of glacial-drift valley aquifers. For average conditions in the hypothetical aquifer, the analytical method predicts a contributing area limited to the well side of the river because a constant-head boundary simulated by image wells is used in the analytical model. For typical glacial-drift, river-valley aquifers, this simulation is unrealistic because drawdowns, caused by a pumping well, and the contributing area of the well can extend beneath and beyond a river or stream.

A wide range of hydrologic conditions was simulated by using the two-dimensional numerical model. The resulting contributing area for a well pumped at $\mathbf{1 . 0}$ million gallons per day-a common pumping rateranged from about 0.9 to 1.8 square miles. Model analyses also show that the contributing area of pumped wells may be expected to extend to the opposite side of the river and to include significant areas of till uplands adjacent to the aquifer on both sides of the valley.

Simulations done with the three-dimensional model allow a full three-dimensional delineation of the zone of contribution for a pumped well. For the relatively thin (100 feet or less) unconfined aquifers considered in this analysis, the threedimensional model showed that the zone of contribution extended throughout the entire saturated thickness of aquifer; therefore, the twodimensional simulations were considered adequate for delineating contributing areas in this particular hydrologic setting. For thicker aquifers, especially those having partially penetrating wells, three-dimensional models are preferable.

Values for several of the factors that affect the size and shape of contributing recharge areas cannot be determined precisely. Therefore, determination, by any method, of the recharge area that contributes water to a pumped well is an approximation at best. Nevertheless, in river valleys where a reasonable amount of accurate geohydrologic data are available, the methods described in this report can be used to estimate the extent of contributing areas with sufficient accuracy to be of use to planners and water-resource managers. 


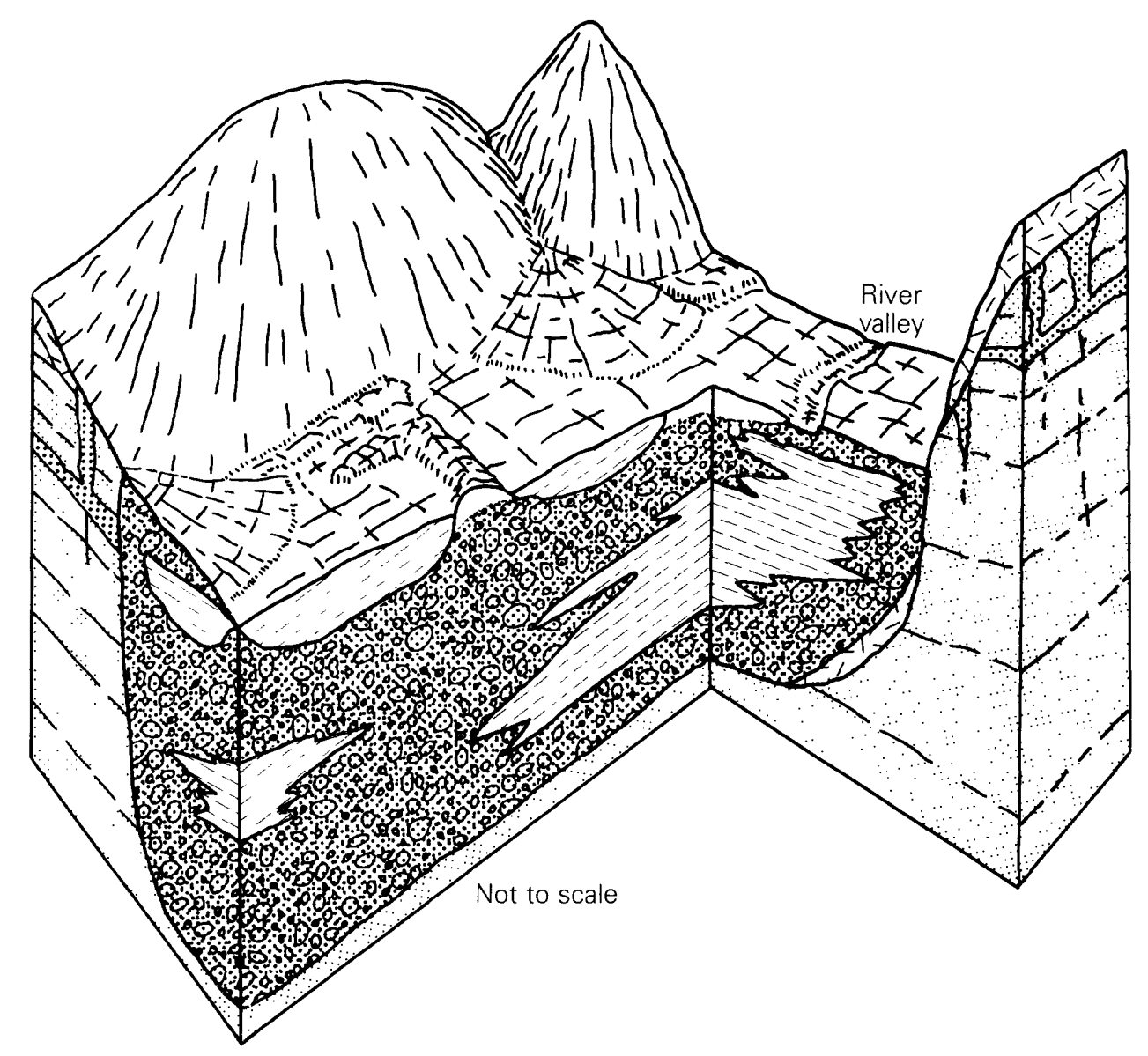

EXPLANATION

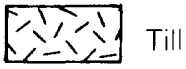

E船- Fractured bedrock

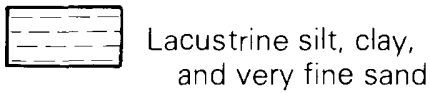

Saral

High-yielding aquifer material

Low-yielding aquifer material

Figure 1. Generalized geologic setting for glacial-drift, river-valley aquifers.

aquifers from natural tributary streams of about $1 \mathrm{ft}^{3}$ per $1,000 \mathrm{ft}$ of stream channel in the Susquehanna River basin, New York. Similar losses have been observed along tributary streams in the Saco River valley in New Hampshire and Maine.

The amount of natural or induced infiltration from surface-water bodies is controlled in part by the difference in head between surface water and ground water and the hydraulic conductivity of streambed and aquifer deposits. In many locations, induced infiltration, caused by pumping in close proximity to a surface-water body, is the largest potential source of recharge to an aquifer (MacNish and others, 1969).

\section{Discharge}

Natural discharge of ground water from stratifieddrift, river-valley aquifers is to surface-water bodies, to wetlands, and through evapotranspiration (fig. 2). During periods of little or no surface runoff, streamflow is essentially ground-water discharge. The amount of total streamflow made up by ground water was shown to be directly proportional to the percentage of total drainage area covered by stratified-drift deposits (Cervione and others, 1972). Ground-water runoff provides as much as 95 percent of the streamflow in drainage areas covered entirely by stratified drift and about 35 percent in till-covered drainage areas. 


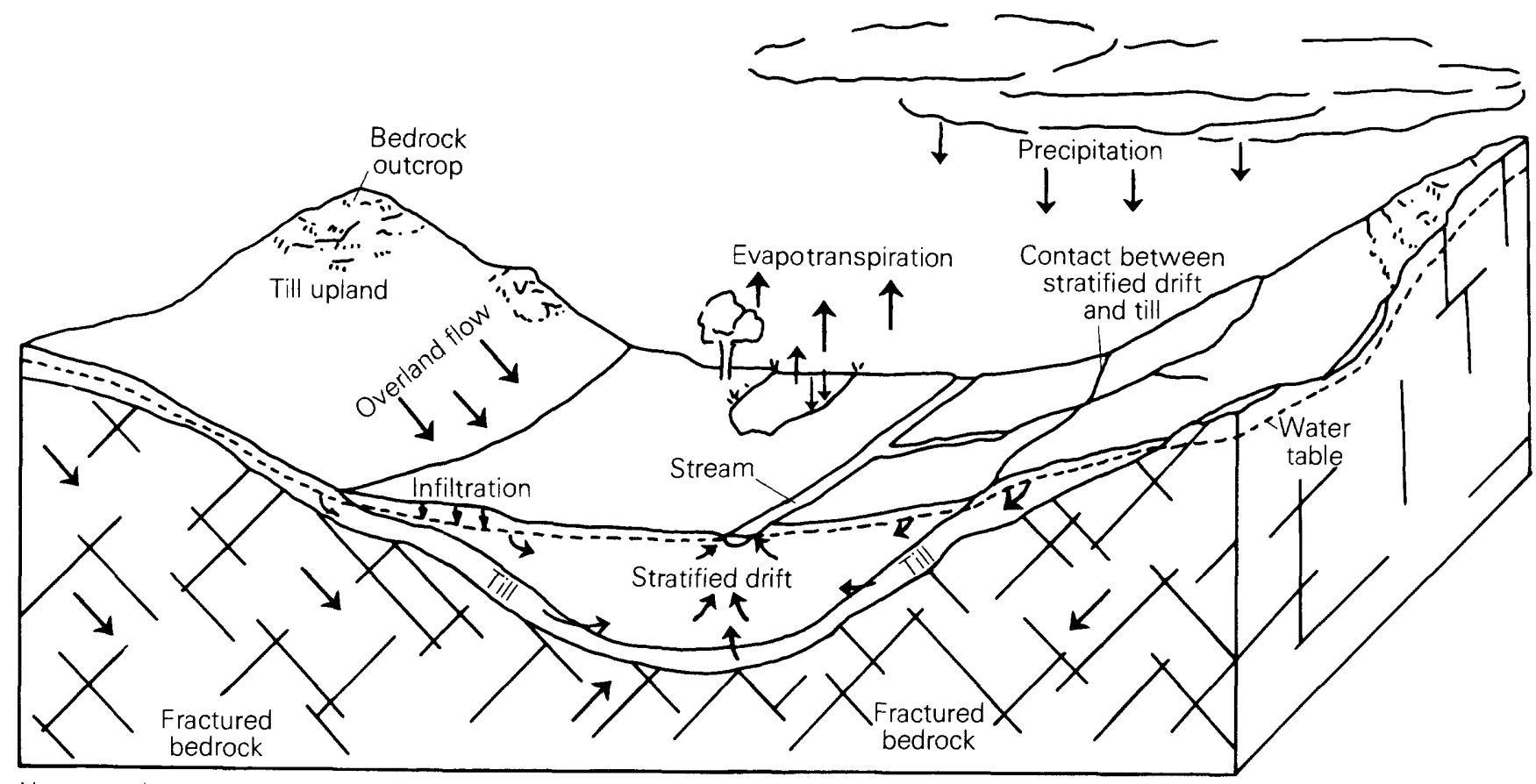

Not to scale

Figure 2. Recharge-discharge relations and flow patterns in glacial-drift, river-valley aquifers.

Estimates of ground-water evapotranspiration from stratified-drift aquifers in the Northeastern United States range from 1 to $9 \mathrm{in} / \mathrm{yr}$ (Lyford and others, 1984). One of the major factors affecting ground-water evapotranspiration losses is depth to the water table below land surface. Where the depth to water is about $10 \mathrm{ft}$ or greater, the loss is probably not significant.

\section{SOURCES OF WATER IN WELLS-A REVIEW}

The economical development and the effective management of any ground-water system require an understanding of the response of the system to withdrawals from wells. The first concise description of the hydrologic principles involved in this response was presented by Theis (1940). Theis pointed out that the response of an aquifer to withdrawals from wells depends on (1) the rate of expansion of the cone of depression, which is caused by withdrawals and depends on the transmissivity and the storage coefficient of the aquifer, (2) the distance to areas in which the rate of water discharging from the aquifer can be reduced, and (3) the distance to recharge areas in which the rate of recharge can be increased.

Over a sufficiently long period of time (prior to the start of withdrawals), the natural discharge $(D)$ from every ground-water system equals the natural recharge $(R)$ (fig. $3)$. For unconfined stratified-drift, river-valley aquifers in the relatively humid northeastern part of the United States, ground-water recharge balances discharge in usually 1 year or less. For shorter periods of time, differences between discharge and recharge involve changes in ground-water storage, as follows:

1 . When the total volume of discharge $\left(D_{\mathrm{v}}\right)$ exceeds the total volume of recharge $\left(R_{\mathrm{v}}\right)$, over a given period of time, ground-water storage $(S)$ is reduced by an amount $\Delta S$ equal to the difference between the volumes of discharge and recharge. Thus,

$$
D_{\mathrm{v}}=R_{\mathrm{v}}+\Delta S \text {. }
$$

2. Conversely, when the total volume of recharge exceeds the total volume of discharge, over a given period of time, ground-water storage is increased. Thus,

$$
D_{\mathrm{v}}=R_{\mathrm{v}}-\Delta S \text {. }
$$

When withdrawal through a well begins, water is removed from storage in the vicinity of the well, and a cone of depression is produced (fig. 4). Thus, the total volume of withdrawal $\left(Q_{\mathrm{v}}\right)$ is balanced by a reduction in ground-water storage. Thus,

$$
Q_{\mathrm{v}}=\Delta S .
$$

As the cone of depression expands outward from the pumping well, it may reach an area where water is discharging from the aquifer. The hydraulic gradient will be reduced toward the discharge area, and the rate of natural discharge $D$ will decrease.

As the decrease in natural discharge compensates for pumpage, the rate at which water is being removed from storage will also decrease, and the rate of expansion of the cone will decline. If the reduction in the rate of natural 


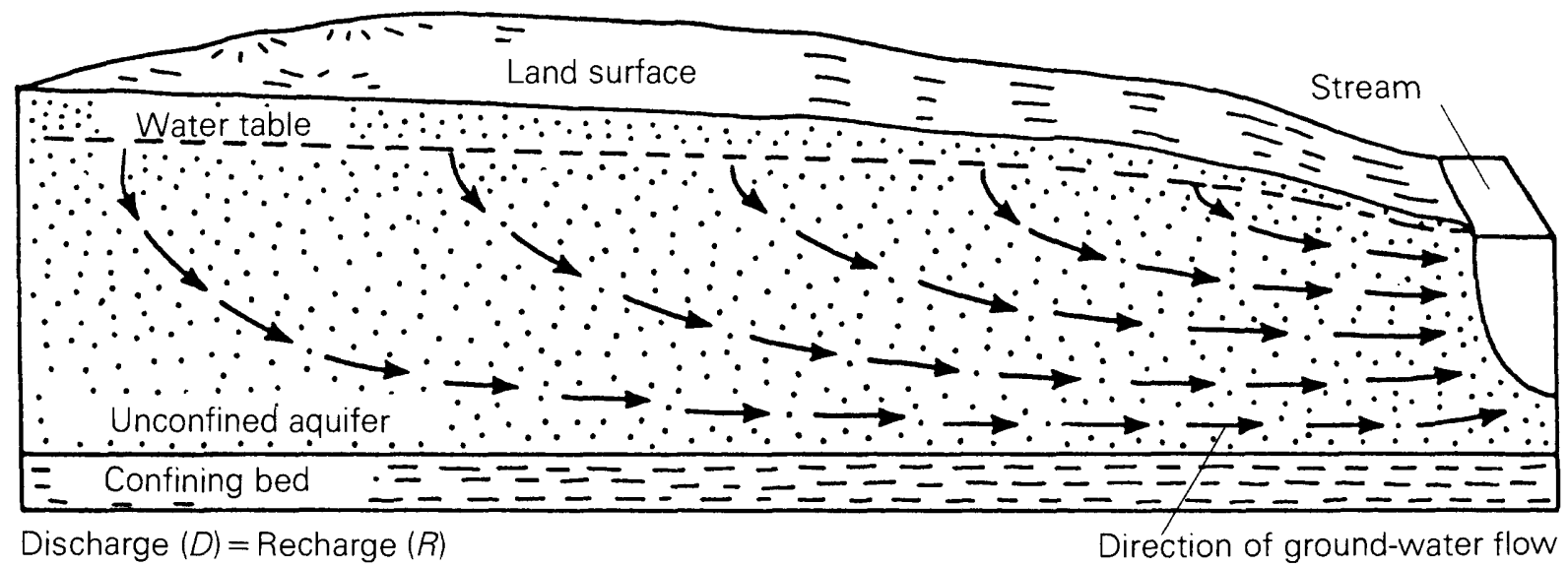

Figure 3. Ground-water flow in the aquifer, natural equilibrium conditions before pumping.

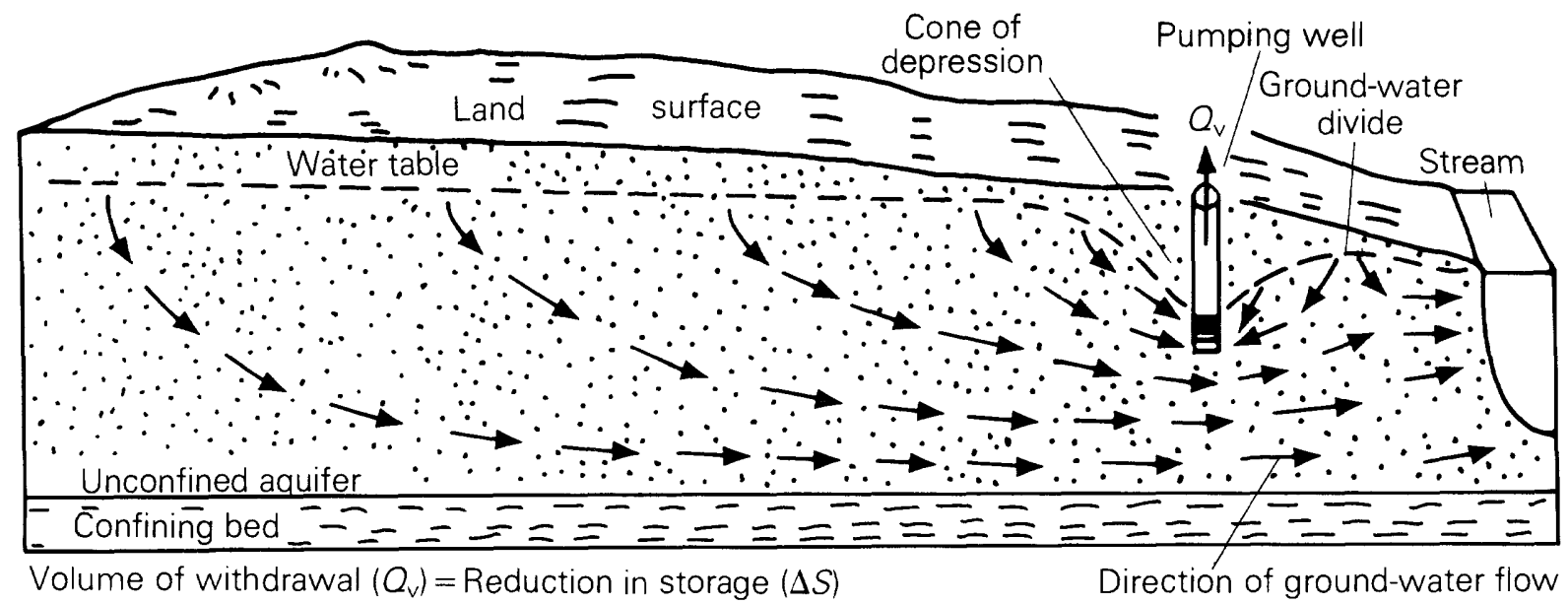

Figure 4. Ground-water flow in the aquifer, early pumping conditions.

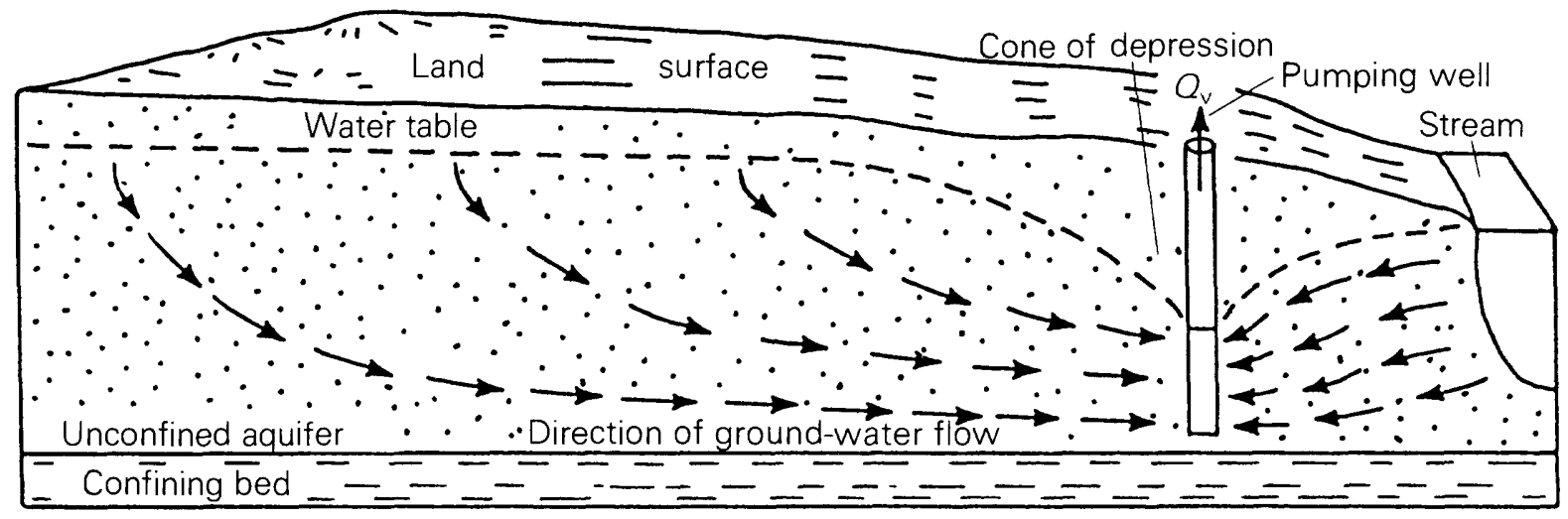

Volume of withdrawal $\left(Q_{v}\right)=$ Reduction in discharge $(\Delta D)+$ Increase in volume of recharge $(\Delta R)$

Figure 5. Ground-water flow in the aquifer, late pumping conditions at equilibrium.

discharge $(\Delta D)$ equals the rate of withdrawal $(Q)$, a new balance will be established in the aquifer. This balance in symbolic form is

$$
(D-\Delta D)+Q=R \text {. }
$$

Conversely, if the cone of depression expands into a recharge area rather than into a natural discharge area, the hydraulic gradient between the recharge area and the pumping well will be increased. If, under natural condi- 


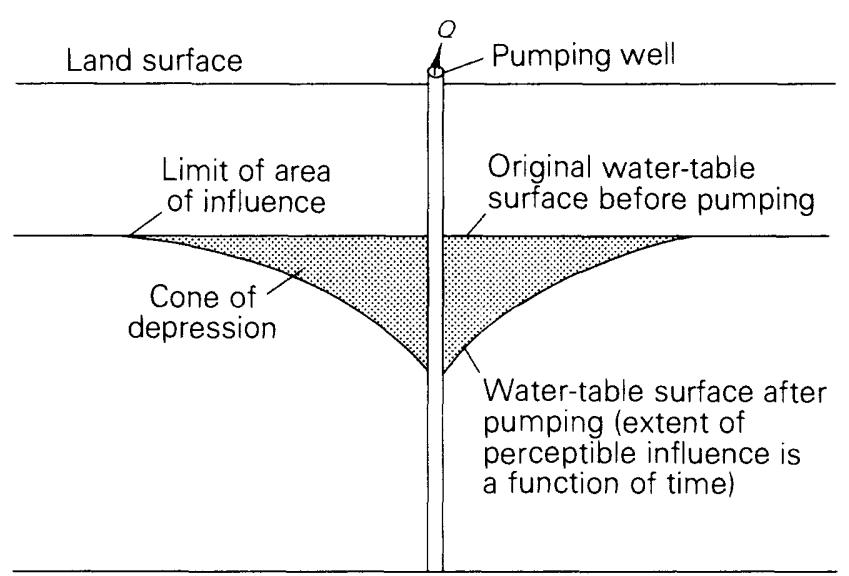

A. Cross-sectional view.

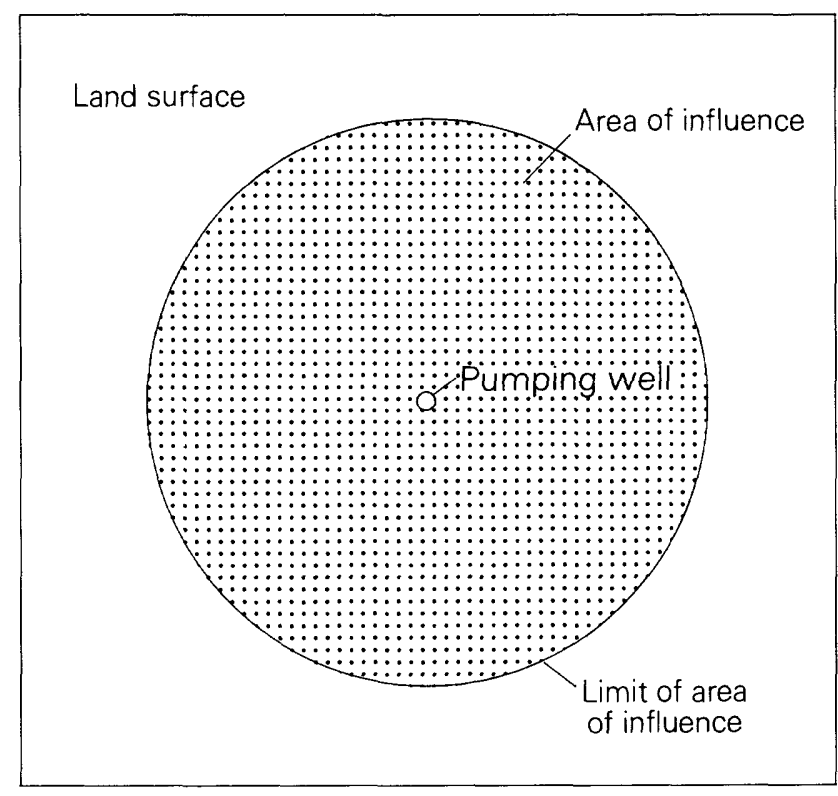

B. Plan view.

Figure 6. $A$, Cone of depression; and, $B$, Area of influence of a pumping well. $Q$, pumping rate.

tions, more water is available in the recharge area than the aquifer can accept (the condition Theis referred to as rejected recharge), the increase in gradient away from the recharge area will permit more recharge to occur, and the rate of growth of the cone of depression will decrease. If the increase in recharge $(\Delta R)$ equals $Q$, a new balance will be established in the aquifer, and the expansion of the cone of depression will cease. The new balance in symbolic form is

$$
D+Q=R+\Delta R \text {. }
$$

In the Northeastern United States, rejected recharge has not been considered to be a major source of water to wells. More commonly, captured natural discharge from an aquifer is the major source of water to a well and limits the expansion of the cone of depression. If the pumping wells are near a stream or if withdrawals are continued long enough, ground-water discharge to a stream may be stopped entirely in the vicinity of the wells, and water may be induced to move from the stream into the aquifer. The tendency in this region is for withdrawals to change discharge areas into recharge areas (fig. 5). This consideration is important where streams contain brackish or polluted water or where streamflow is committed to other purposes.

To summarize, the withdrawal of ground water through a well reduces the water in storage in the source aquifer during the growth of the cone of depression. If the cone of depression ceases to expand, the rate of withdrawal is balanced by a reduction in the rate of natural discharge and (or) by an increase in the rate of recharge. Under this condition:

$$
Q_{v}=\Delta D+\Delta R \text {. }
$$

Also, a ground-water divide exists between the well and the stream (indicated in figure 4 by directions of flow in opposite directions), signifying a reduction in natural discharge to the stream caused by the pumping well. In contrast, flow directly from the stream to the well is illustrated in figure 5 .

These concepts, as applied to stratified-drift, rivervalley aquifers in Rhode Island and elsewhere in New England, have several important ramifications. In this area, water pumped from wells will be derived from (1) storage in the aquifer, (2) reduction of ground-water flow to nearby streams, and (3), possibly, induced infiltration from streams. The latter two mechanisms (one or both of which are operative during extended periods of pumping) will reduce streamflow and thus can produce an undesirable result where downstream user rights are affected. Furthermore, if the quality of the surface water is distinctly inferior to the quality of ground water, induced infiltration from the stream can effect the quality of water pumped from the well.

\section{THE CONCEPT OF CONTRIBUTING AREA}

\section{Definitions}

The cone of depression is the cone-shaped geometric solid formed, after a well has begun discharging, between the water table (or other potentiometric surface) and the original position of the water table (Theis, 1938). Although the drawdown travels radially outward in the saturated sand at a speed approaching that of sound, the measurable influences travel much more slowly (Jacob, 1949). This depression in the water table (or other potentiometric surface) is shown in figure $6 \mathrm{~A}$.

The area of influence of a pumping well is the land area that directly overlies and has the same horizontal extent as the part of the water table or other potentiometric surface that is perceptibly lowered by the withdrawal of water 


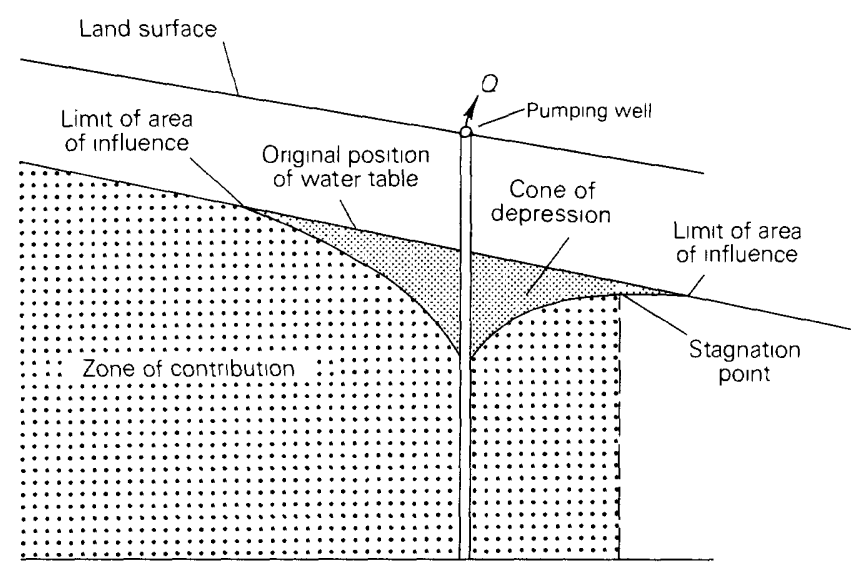

A. Cross-sectional view.

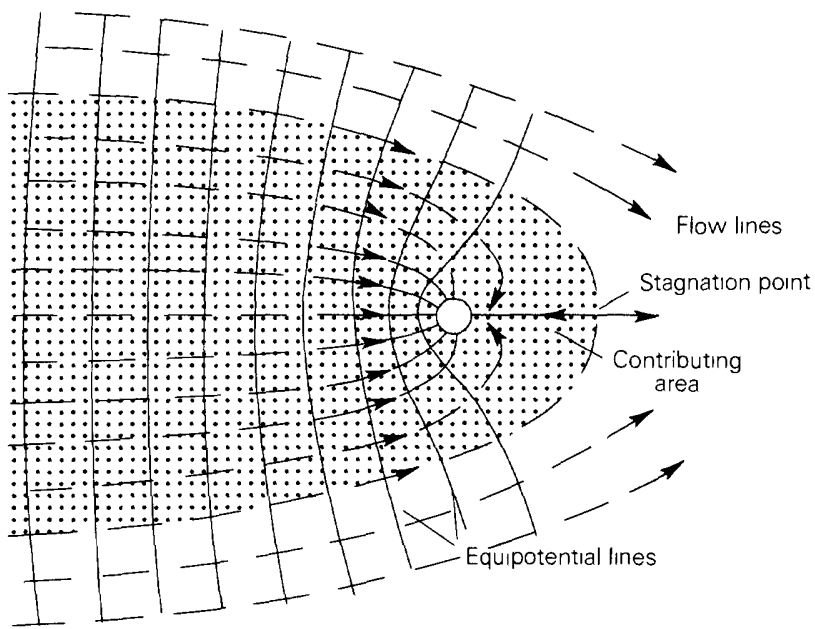

B. Plan view.

Figure 7. $A$, Zone of contribution; and, $B$, Contributing area of a pumping well. $Q$, pumping rate.

(Meinzer, 1923). The area of influence can be visualized as a two-dimensional area on the land surface as shown in figure $6 B$. In an isotropic aquifer, the area of influence is circular; in an anisotropic aquifer, the area of influence is elliptical.

The zone of contribution of a pumping well is here defined as the volumetric portion of an aquifer from which ground-water flow is diverted to a pumping well. The zone of contribution can be visualized as a three-dimensional section of the aquifer (fig. 7).

The contributing area (sometimes referred to as area of diversion) of a pumping well is the land area that has the same horizontal extent as that part of an aquifer, or adjacent areas, from which ground-water flow is diverted to the pumping well. The contributing area for a pumping well can be visualized as a two-dimensional area on the land surface as shown in figure $7 B$.

A typical high-yield aquifer in New England is made up of coarse-grained, unconsolidated, stratified drift con- taining a thin, highly permeable unsaturated zone. In this geohydrologic setting, significant amounts of recharge to the water table can occur near pumping wells. Of course, recharge containing contaminants in a contributing area can adversely affect the quality of water obtained from a well. Therefore, efforts to protect the quality of water obtained from a well must be at least partially directed toward protection of these important source areas.

The misconception that contributing area and area of influence are identical persists despite an excellent discussion by Brown (1963). (This confusion may have contributed to the use of circular areas around wells as buffer zones for ground-water-quality protection.) Actually, these areas can be the same only in the hypothetical circumstances where the prepumping water table is perfectly flat and all aquifer properties are uniform within the area of influence. Where the prepumping water table has a gradient, as is the case in most natural conditions, the contributing area to a well will be distorted to extend to a greater distance on the upgradient side and to a lesser distance on the downgradient side.

Consider the hypothetical aquifer shown in figure 8. The aquifer is unconfined and recharged only from precipitation $(W)$. Discharge from the aquifer is to a river that cuts through the entire saturated thickness of the aquifer and to

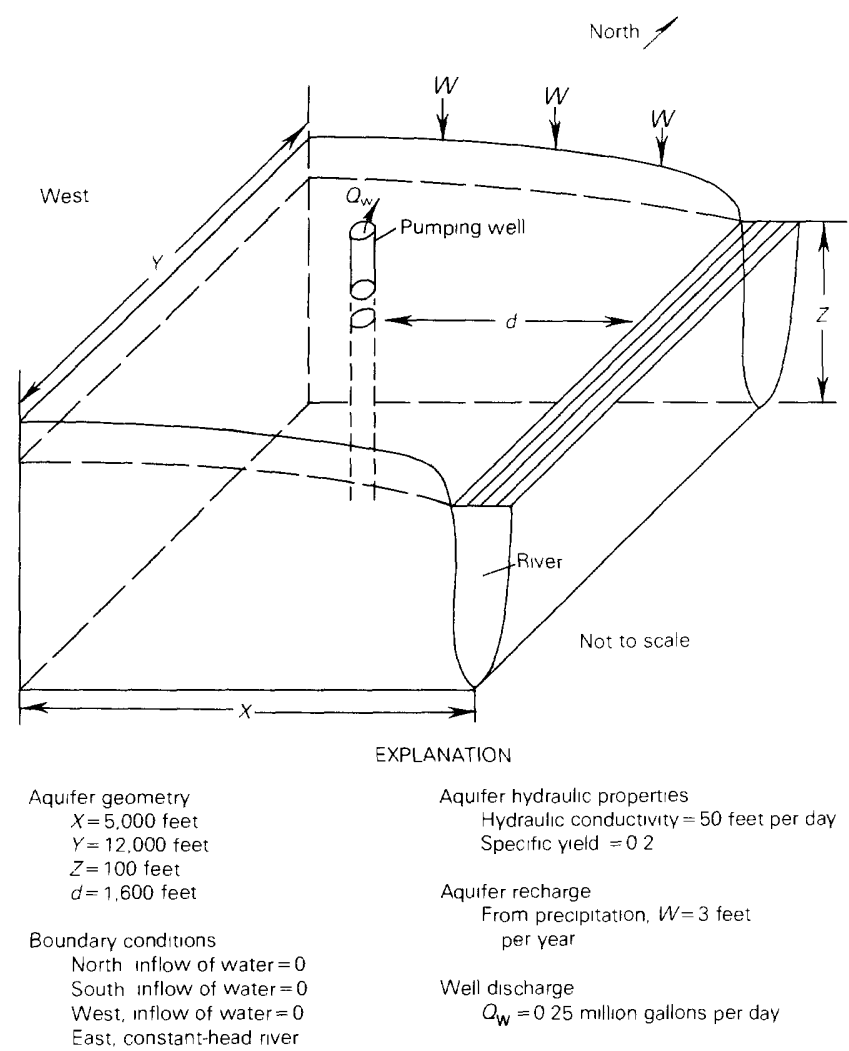

Figure 8. Geohydrologic features of the hypothetical aquifer used in figure 9 to illustrate the difference between the area of influence and the contributing area of a pumped well. 
a well located in the center of the aquifer at a distance $(d)$ from the river. Values that describe the geometry, hydraulic properties, boundary conditions, and recharge and discharge rates for the aquifer are shown on figure 8 . This hypothetical aquifer is used (fig. 9) to illustrate the difference between the area of influence and the contributing area of a pumped well.

The equilibrium water-table configuration and flow directions in the aquifer for nonpumping conditions are shown in plan view in figure $9 A$. The drawdowns and area of influence for steady-state pumping conditions are shown in figure $9 B$. (For the purpose of this discussion, the area of influence is defined as that area where drawdowns caused by the well are $0.1 \mathrm{ft}$ or greater.) Theoretically, very small drawdowns occur at the boundaries of the aquifer even though they might not be reliably measured in the field. The equilibrium water-table configuration, flow directions in the aquifer, and contributing area for pumping conditions are shown in figure $9 C$.

The results shown in figure 9 were determined by using a numerical ground-water-flow model developed by Trescott and others (1976). The flow nets, contributing area, and area of influence shown in the illustration were constructed graphically from model output. A detailed description of this method of analysis is presented in the two-dimensional model analysis section.

The difference between the area of influence and the area of contribution, for the hypothetical aquifer shown in figure 8 , are clearly evident when figures $9 B$ and $9 C$ are compared. The contributing area of the pumping well covers about $0.15 \mathrm{mi}^{2}$ and extends from the western boundary of the aquifer to a point about $350 \mathrm{ft}$ down gradient from the well, while the area of influence covers almost the entire aquifer $\left(2 \mathrm{mi}^{2}\right)$. Recharge into the contributing area from precipitation exactly balances well discharge for the equilibrium conditions shown in figure $9 C$.

The area of influence caused by a pumping well is limited only by the physical boundaries of the aquifer in which the well is located. The contributing area of a pumping well will be limited to the area around the well in which captured water balances well discharge. The captured water can consist of a decrease in aquifer storage, increased

Table 1. Factors affecting contributing area

\begin{tabular}{l}
\hline Number \\
\hline 1. $\ldots \ldots$. Fell discharge rate and duration of pumping period. \\
2. $\ldots \ldots$ Aquifer transmissivity. \\
3. $\ldots \ldots$ Aquifer storage coefficient or specific yield. \\
4. $\ldots \ldots$ Proximity of the pumping well to aquifer boundaries. \\
5. $\ldots \ldots$ Spatial and temporal variations in aquifer transmis- \\
sivity and (or) storage coefficient. \\
6. $\quad \ldots \ldots$ Spatial and temporal variations in aquifer recharge. \\
7. $\ldots \ldots$ Partial penetration of the pumping well. \\
8. $\ldots \ldots$ The presence of extensive confining layers. \\
\hline
\end{tabular}

recharge (usually in the form of induced infiltration from a surface-water body), and (or) decreased natural discharge from the aquifer.

\section{Factors Affecting the Contributing Area of a Well}

On the basis of the discussion of the sources of water derived by wells and the work of previous investigators (Theis, 1940; Jacob, 1949; DaCosta and Bennett, 1960; Brown, 1963; Mazzaferro, 1989; and Keely, 1984), several factors (table 1) have been shown to affect the area that contributes flow to a pumping well.

All geohydrologic factors that can affect the two- or three-dimensional flow field around a pumping well can also affect the contributing area to the well, depending on specific conditions at the site. For unusual geohydrologic conditions, there may be additional factors that have not been listed in table 1 . The critical geohydrologic factors at a specific site will determine which method will be best suited for estimating a contributing area.

\section{Selected Methods for Estimating Contributing Area}

Delineation of the contributing area for a pumping well involves the construction of a flow net. A flow net is used to determine areas in an aquifer where ground-water flow is captured by a well or wells (contributing areas).

A flow net (fig. 9C) consists of a set of equipotential lines and flow lines. The equipotential lines connect locations of equal head in the aquifer. The flow lines, oriented perpendicular to the equipotential lines (for an isotropic aquifer), show directions of ground-water flow. The flow net shown in figure $9 C$ is two-dimensional; that is, the flow net is drawn on a horizontal plane and is based on the assumption that no vertical components of flow exist in the aquifer.

Several methods are available for generating the data necessary to construct flow nets. These include graphical techniques, analog simulation (conductive paper, resistorcapacitor networks, sand box), analytical-mathematical techniques, and numerical-mathematical simulations. Discussions of flow-net construction can be found in Freeze and Cherry (1979) and Todd (1980). The most commonly used methods, and the ones that will be described in this report, are analytical-mathematical techniques and numerical-mathematical simulation.

\section{Analytical Model}

Analytical models are commonly used to determine aquifer characteristics from pumping tests. If aquifer characteristics are known or can be estimated, the same analytical models can be used to predict drawdowns that will 


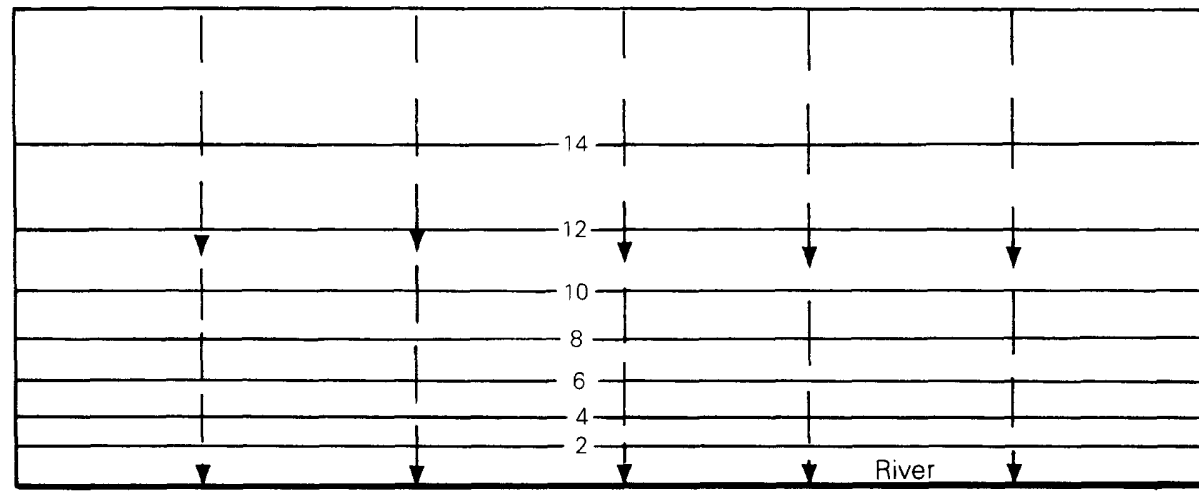

A

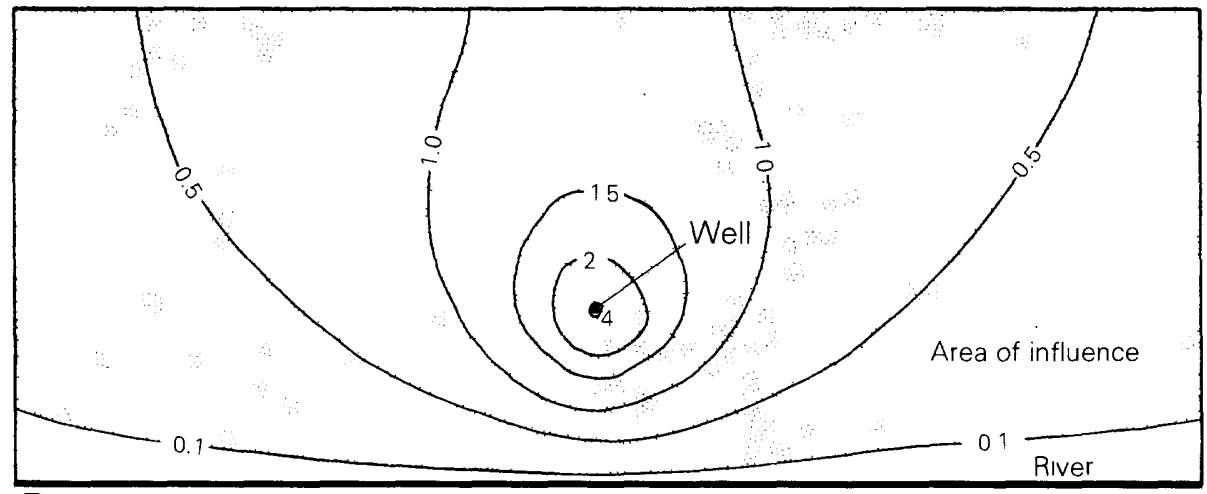

B
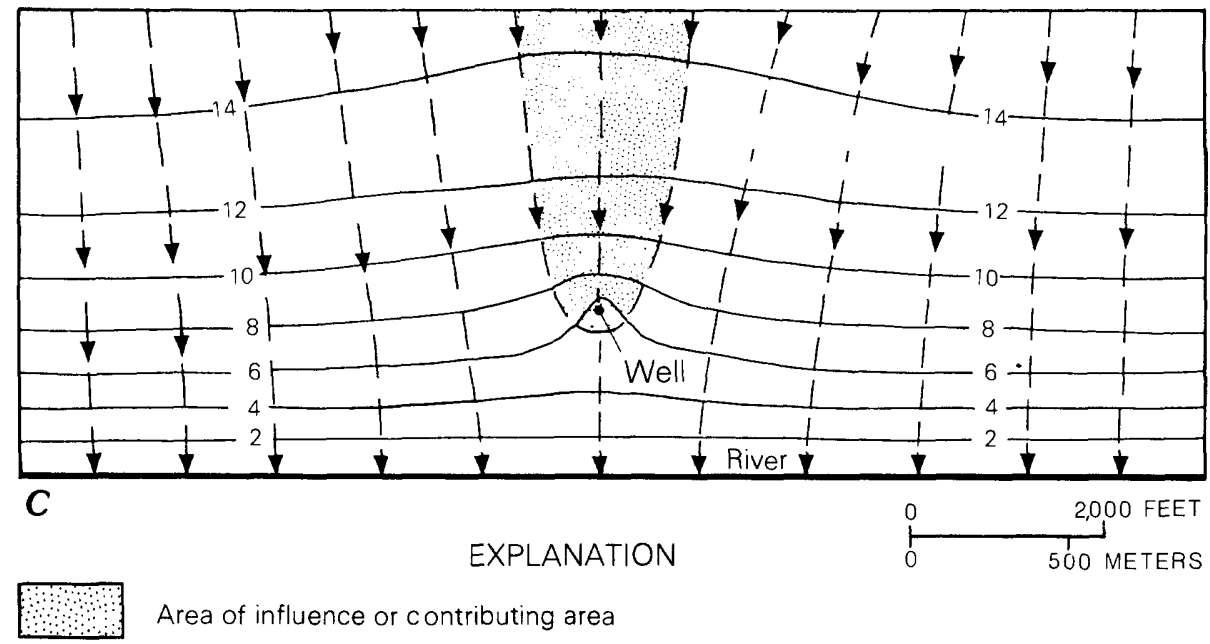

Area of influence or contributing area

- $10-$ Equipotential Iine-Interval, in feet, is variable

$\longrightarrow$ Direction of ground-water flow-Flow lines

For all figures, units of head and drawdown are expressed in feet relative to river stage

Figure 9. Plan views of a hypothetical aquifer, illustrated in figure 8 , showing, $A$, Prepumping flow net (equilibrium water-table configuration and flow directions); $B$, Steady-state drawdowns and the area of influence of a pumped well; and, $C$, Flow net (equilibrium water-table configuration and flow directions) and contributing area for pumping conditions. 

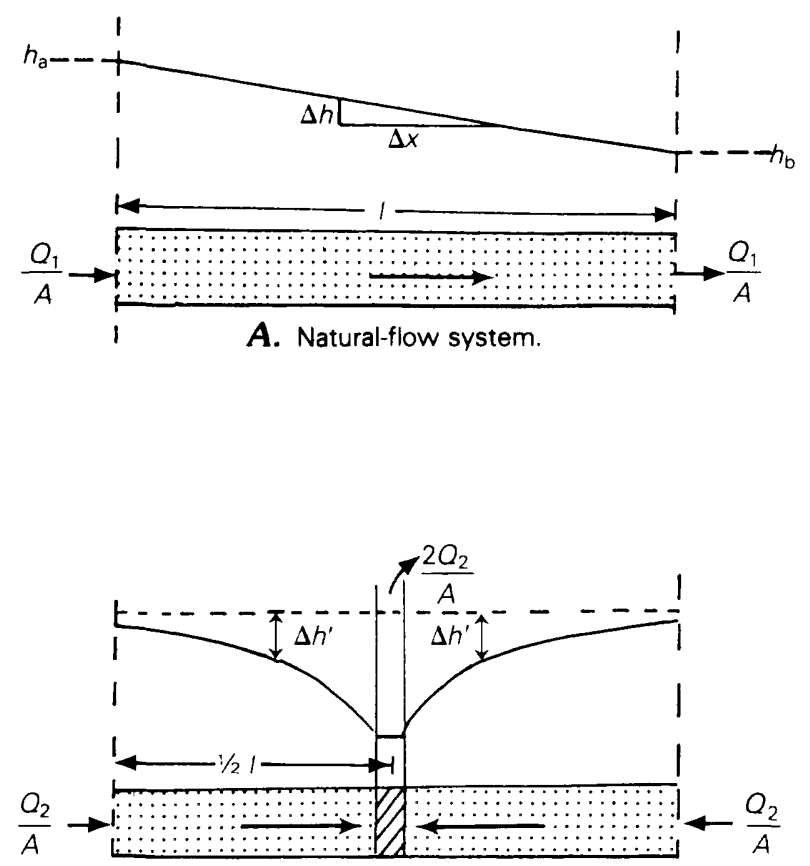

B. Solution of stressed system (expressed in terms of head change or drawdown).

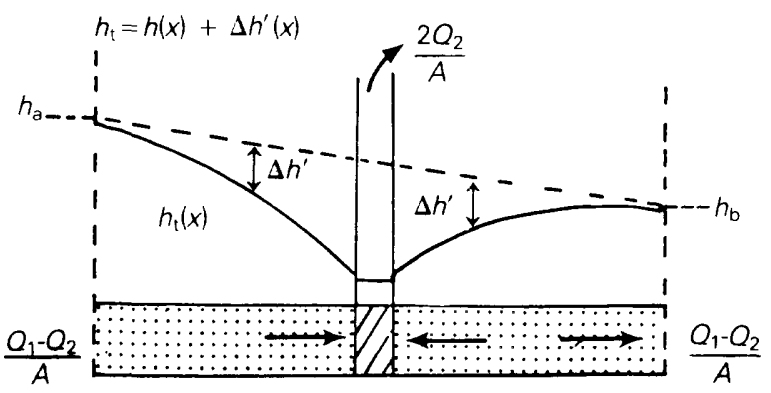

C. Superposition of solutions (steady-state conditions assumed).

\section{EXPLANATION}

$h_{\mathrm{a}}$ Head in the aquifer at point $\mathrm{a}$, in feet

$h_{b}$ Head in the aquifer at point $b$, in feet

$\Delta h / \Delta x \quad C h a n g e$ in head per unit distance in the aquifer, in feet per foot

I Length of flow system, in feet

$Q_{1} / A$ Boundary inflow and outflow per unit area for nonpumping equilibrium conditions, in cubic feet per unit time per square foot (feet per unit time)

$O_{2} / A \quad$ Boundary inflow per unit area for pumping conditions

$\Delta h^{\prime} \quad$ Drawdown caused by pumping well, in feet

$2 \mathrm{Q}_{2} / \mathrm{A}$ Total pumping rate of well

$h_{1} \quad$ Head distribution resulting from superposition of natural and stressed systems

$\underline{Q_{1}-Q_{2}}$ Boundary inflow and outflow per unit area resulting from superposition of natural and stressed systems

$\longrightarrow$ Direction of ground-water flow

Figure 10. $A$, Head distribution; $B$, Drawdowns caused by a pumping stress; and, $C$, Head distribution resulting from superposition of $A$ and $B$. (See text for discussion of method.) occur in the vicinity of a well because of pumping stress. The use of analytical methods requires simplification of aquifer geometry and hydraulic properties.

Some typical simplifications are that aquifer properties are homogeneous and isotropic and that the aquifer is confined. In addition, analytical methods often assume that drawdowns caused by a well are unaffected by aquifer boundaries. If boundaries are present, they must be conceptualized as being perfectly straight and as having uniform properties.

To estimate a contributing area by using analytical techniques, the drawdowns determined by using the model must be superimposed on (subtracted from) a prepumping water-table surface. The principle and application of superposition in ground-water hydraulics are discussed in detail by Reilly and others (1984). Assume that the head distribution $(h)$ and boundary flows $\left(Q_{1}\right)$ of an unstressed confined aquifer are known (fig. 10A). Also known are the drawdown distribution $(\Delta h)$, relative to an arbitrary datum, and the boundary flows $\left(Q_{2}\right)$, in response to a hypothetical pumping stress $\left(2 Q_{2}\right)$ (fig. 10B). Both the natural-flow system and the stressed-flow system are assumed to be at steady-state. Superposition of the natural and stressed system results in the head distribution $\left(h_{\mathrm{t}}\right)$ and boundary flows $\left(Q_{1} \pm Q_{2}\right)$ shown in figure $10 C$. Although illustrated in cross section in figure 10, the procedure is carried out in plan view to determine the contributing area for a pumped well.

If the regional drawdowns that will be caused by a pumping well are less than 10 percent of the total saturated thickness of an unconfined aquifer, the use of superposition in an unconfined system may be acceptable (Reilly and others, 1984). In a strict sense, superposition is mathematically correct only for confined aquifers because linear equations describe flow in confined aquifers. Superposition can be used for unconfined aquifers only as an approximation because flow in unconfined aquifers is described by nonlinear equations. The use of analytical models to estimate contributing areas of unconfined aquifers requires that a prepumping water-table map be available and that the use of superposition be considered to be mathematically appropriate; that is, when the effects on nonlinearity are acceptable.

Typical glacial-drift, river-valley aquifers are almost never homogeneous, isotropic, or confined. They are characterized by abrupt changes in hydraulic properties in both horizontal and vertical directions. Pumping wells in glacialdrift, river-valley aquifers are usually affected by the presence of complicated boundaries such as surface-water bodies that have leaky bottoms and semipermeable valley walls. Therefore, significant errors can be made when analytical methods and superposition are used to estimate contributing areas in glacial-drift, river-valley aquifers.

Despite these problems, analytical techniques can provide reasonable estimates of flow patterns around wells 
in glacial-drift aquifers under certain conditions. Analytical models can be used to simulate factors $1-3$ from table 1 . Factor 4 can be simulated if the aquifer boundaries can be idealized. To use analytical models accurately, the inherent hydrological assumptions and affects of these assumptions on results must be carefully considered. No analytical model can be used in every situation to estimate contributing areas for wells in glacial-drift aquifers. The suitability of an analytical approach must be considered on a siteby-site basis.

Analytical models may require only pencil and paper and can be solved in a short amount of time. In addition, analytical solutions can provide insight into the dependence of a solution on input data-such as boundary conditions, hydraulic properties, and the relative location of a point of interest with respect to spatial boundaries. Because of these advantages, analytical models are excellent to use for preliminary analyses or feasibility studies.

Analytical models that might be useful for determining the effects of wells in glacial-drift, river-valley aquifers include the Theis equation as modified by image well theory (Ferris and others, 1962), a method for determining the effect of a well located near a semipervious streambed (Hantush, 1965), and a method for determining the effect of a well in a uniform flow field (Bear, 1979). Equations for determining steady-state drawdowns caused by a well in an infinite strip aquifer that has various boundary conditions are given by Kirkham $(1949,1951)$ and Rorabaugh (1956). Additional analytical models can be found in Bear (1979), Freeze and Cherry (1979), Lohman (1979), and Todd (1980).

\section{Two-Dimensional Numerical Model}

Two-dimensional, mathematical numerical groundwater-flow models have become the most commonly used tool for analyzing the response of an aquifer to stress. Numerical models have gained in popularity because they can address a wide range of complicated field problems that cannot be analyzed by analytical methods. A twodimensional ground-water-flow model can simulate all of the previously listed factors that can affect the contributing area for a well except for those that involve vertical flow (table 1, factors 7 and 8 ).

Two-dimensional numerical models can be used to simulate the horizontal flow of ground water in heterogeneous, anisotropic aquifers that are either confined or unconfined. Therefore, a zone of diversion, estimated by using a two-dimensional numerical model, is assumed to extend through the entire saturated thickness of an aquifer. These models also can simulate irregular, mixed boundary conditions and complicated combinations of aquifer recharge and discharge. By using variable grid spacings, numerical models can be designed to provide greater detail in areas of special interest.
An important limitation of two-dimensional numerical models is their inability to simulate vertical flow in an aquifer. For the relatively thin aquifers found in New England, this constraint is not serious except in areas where vertical flow is predominant, such as near recharge or discharge areas. The advent of computers that have sufficient storage to handle the necessary codes and data arrays has increased the usefulness of numerical models.

Numerical solutions are approximations of the exact solution of equations that describe ground-water flow, and, therefore, some error (discretization error) may be involved. The accuracy of a finite-difference numerical solution is related to the choice of the size of the grid blocks used to represent the aquifer. In most real world applications of such approximation methods, the accuracy associated with an arbitrary choice of a specific grid cannot be determined exactly. In practice, what can be done to select an acceptable grid is to start with an arbitrary grid and then make simulation runs by using increasingly more refined grids until the computed results do not change more than a specified amount. Although the grid size was not varied for this study, the grid block size used is presumed to be small enough that the qualitative character of the approximate solutions is acceptably close to that of the unknown exact solutions to give useful information. Remson and others (1971) provide a useful discussion on discretization error.

Some references that will provide an introduction to both the theoretical and the applied aspects of numerical ground-water-flow modeling are Bennett (1976), Mercer and Faust (1981), and Wang and Anderson (1982). Commonly used two dimensional ground-water-flow models are those developed by Prickett and Lonnquist (1971), Trescott and others (1976), and McDonald and Harbaugh (1984).

\section{Three-Dimensional Numerical Model}

A three-dimensional numerical ground-water-flow model can be used to simulate all of the factors from table 1 that can affect the contributing area for a well. The three-dimensional model codes take into account horizontal and vertical variations in geometry, hydraulic properties, and recharge or discharge within an aquifer. This type of model will allow estimation of the three-dimensional shape of a zone of diversion, which is particularly useful in very thick aquifers. Three-dimensional models, however, are limited by the need for extensive data for model construction and calibration and for a computer that has sufficient storage to handle the computer program and associated data arrays.

Three-dimensional simulations can be accomplished either by using a quasi-three-dimensional approach by stacking two-dimensional models or by actually simulating the equations that describe the three-dimensional flow of ground water. Confining layers can be simulated by using leakage terms or with discrete layers in the model. Because of the vertical layering inherent in a three-dimensional 


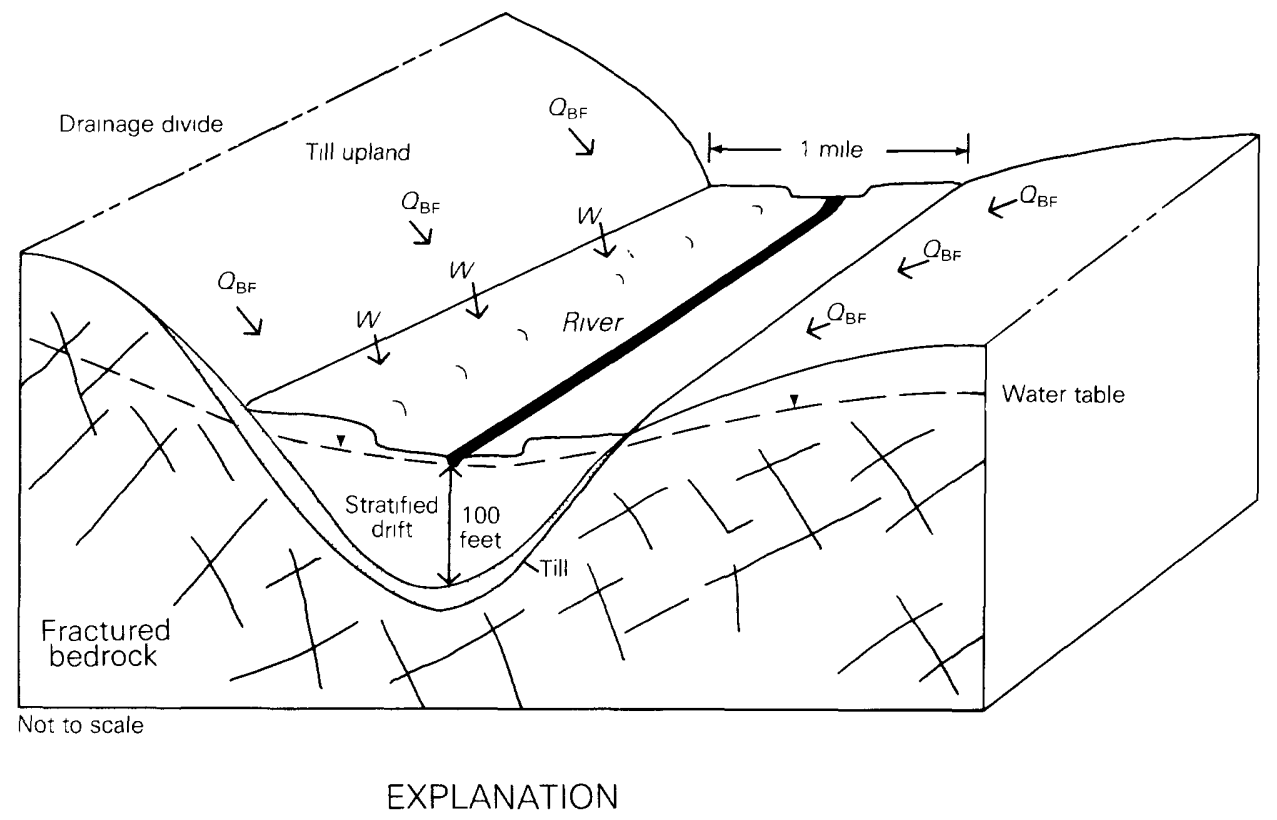

$W$. Aquifer recharge from precipitation

$Q_{\mathrm{BF}}$, Boundary flux, recharge from till upland areas

Figure 11. Geohydrologic features of the hypothetical stratified-drift, river-valley aquifer addressed in the model analyses.

model, simulating partial penetration of a well or surfacewater body is relatively easy. Partial penetration means that the well screen or surface-water body is not in contact with the entire saturated thickness of an aquifer.

A three-dimensional ground-water-model developed by Trescott (1975), and subsequently modified by Trescott and Larson (1976) and Torak (1982), has been successfully applied to solve a variety of ground water flow problems. A more recent model, developed by McDonald and Harbaugh (1984), has a modular coding structure that allows simulation of various geohydrologic conditions, such as leakage to rivers and evapotranspiration. Individual software packages can incorporated into the program as needed.

\section{CONTRIBUTING AREA ANALYSIS AND SENSITIVITY TESTING}

The size and shape of contributing areas are affected by many geohydrologic factors. Analytical and numerical models were used to test the sensitivity of contributing areas to variations in well discharge rate, aquifer recharge, streambed permeability, aquifer hydraulic conductivity, boundary conditions, and well penetration. The testing was done on a hypothetical glacial-drift, river-valley aquifer that is typical of aquifers found throughout New England.

\section{A Hypothetical Glacial-Drift, River-Valley Aquifer System}

The hypothetical aquifer is made up of stratified-drift deposits that have no extensive confining layers. Ground water exists everywhere under unconfined conditions. The drift deposits fill the bottom of a U-shaped valley cut in crystalline bedrock as shown in figure 11. Impermeable till forms a discontinuous layer between the drift and bedrock and lies over bedrock in upland areas. The stratified-drift deposits are approximately $1 \mathrm{mi}$ wide across the valley floor, extend for several miles along the river valley, and have a saturated thickness that ranges from about $20 \mathrm{ft}$ near the till-drift boundary at the valley walls to $100 \mathrm{ft}$ in the center of the valley. Aquifer hydraulic conductivity ranges from about $10 \mathrm{ft} / \mathrm{d}$ along the till-drift boundary to $100 \mathrm{ft} / \mathrm{d}$ in the center of the valley. Specific yield equals 20 percent throughout the aquifer.

Recharge from precipitation averages $2 \mathrm{ft} / \mathrm{yr}$; recharge from surface-water and ground-water runoff originating in the till uplands bordering the valley fill is assumed to be $0.6(\mathrm{ft} / \mathrm{yr}) / \mathrm{mi}^{2}$ of till upland. Discharge from the aquifer is through the permeable streambed of a river that lies atop the stratified-drift deposits. The river has a relatively flat gradient, and bottom deposits have a permeability of $2 \mathrm{ft} / \mathrm{d}$ and a thickness of $2 \mathrm{ft}$.

The bottom of the hypothetical system is defined as the contact between stratified drift and till and is assumed to 
be an impermeable or no-flow boundary. In reality, some flow crosses this type of boundary, but, because of the large contrast in permeability between till and stratified drift, flow is assumed to be negligible. The top of the aquifer is the water table, which is a free-surface boundary that can move up or down depending upon the balance of stresses within the aquifer. The lateral extent of the system is marked by the contact between saturated stratified drift and till or bedrock valley walls. Inflow of water from upland areas is assumed to occur along these boundaries.

River-valley aquifer studies done in New England were used to guide the conceptualization of the hypothetical aquifer so the parameters would be reasonable and representative of actual field conditions. Examples include studies by Rosenshein and others (1968), Haeni (1978), Mazzaferro (1980), Morrissey (1983), Olimpio and de Lima (1984), and Dickerman and Ozbilgin (1985).

\section{Analytical-Model Analysis}

The analytical model used in this analysis is based on the Theis (1940) nonequilibrium formula as modified by Ferris and others (1962) for simulation of constant-head or impermeable boundary conditions. The model provides corrections for partial penetration of the pumping well, for variations in transmissivity because of dewatering, and for the drawdowns of any nearby pumping wells. The model requires the aquifer to be idealized as a rectangular area defined by various combinations of impermeable-barrier, line-source constant-head, and open (infinite) boundaries. The model is programmed in a code that is suitable for use on many different computers. A more detailed description of the model can be found in Mazzaferro and others (1979).

\section{Procedure for Contributing-Area Estimation}

To apply an analytical model to estimate a contributing area:

1. Make assumptions necessary to idealize the real aquifer. In this study: (a) the real aquifer was idealized as a rectangular area; (b) the boundary conditions along each edge of the rectangle were defined as either impermeable, constant-head, or infinite; (c) uniform hydraulic properties (transmissivity and storage coefficient) within the rectangle were defined; and (d) the rate and duration of pumping were specified.

2. Determine drawdowns caused by the pumping stress.

3. Check to see if drawdowns predicted by the analytical model are small ( 10 percent or less) with respect to the saturated thickness of the unconfined aquifer. If they are, proceed to next step. If drawdowns are greater then 10 percent of saturated thickness, superposition may yield incorrect results. In this case, a different method of analysis, such as numerical modeling, should be used that can account for the changes in transmissivity caused by dewatering of the aquifer.

4. Superimpose (subtract) the drawdowns determined with the analytical model on a water-table map of the natural system that does not reflect the pumping stress under study. If the desired result is a conservatively large contributing area, the prepumping water-table map should reflect the lowest expected ground-water altitudes for the aquifer being studied.

5. Construct a flow net from the resulting water-table map. For a flow net in homogeneous, isotropic media, the rules for graphic construction of flow nets are as follows: (a) flow lines and equipotential lines must intersect at right angles throughout the system; (b) equipotential lines must meet impermeable boundaries at right angles; and (c) equipotential lines must parallel constant-head boundaries.

6. Determine the flow lines dividing the regional flow field from the flow field around the pumping well.

7. Estimate areas adjacent to the aquifer, such as till upland, that may be included in the contributing area of the pumping well.

The simplification of the real aquifer system required for analytical model analysis can affect the size and shape of a modeled contributing area and yield misleading results. These simplifications can be related to aquifer geometry, hydraulic properties, and especially to boundary conditions. Also, superposition is only an approximation. The degree to which this approximation affects results should be examined on a case-by-case basis. Finally, the prepumping water-table map on which drawdowns are superimposed will affect the size and shape of a contributing area. In many cases, these maps may not be available for extreme lowwater conditions. As a result, the estimated contributing area for a well can be smaller than the contributing area resulting from actual low-water conditions.

\section{Application}

In the analytical model simulation, the river was treated as a constant-head boundary that acts as an unlimited source of water for the pumping well. In reality, this situation will occur where a river cuts through the entire saturated thickness of an aquifer (fully penetrating) or if a streambed and aquifer are so highly permeable they do not impede flow between the river and aquifer (fig. 12).

In this simulation, the well, pumping $1.0 \mathrm{Mgal} / \mathrm{d}$, was located near the center of the valley, $200 \mathrm{ft}$ from the river. The contact between the stratified-drift deposit and the valley walls was treated as an impermeable boundary. Because the hypothetical aquifer is several miles long, the end boundaries in the model were left open to simulate infinite conditions. Transmissivity was assumed to average $7,500 \mathrm{ft}^{2} / \mathrm{d}$, and specific yield was assumed to be 20 percent over the entire area of the idealized aquifer. 


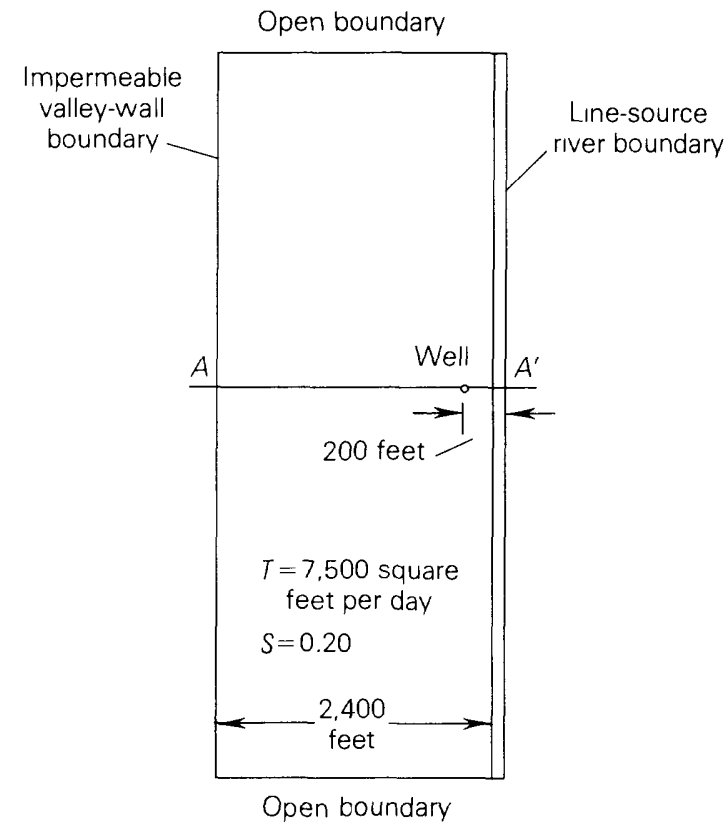

A. Plan view.

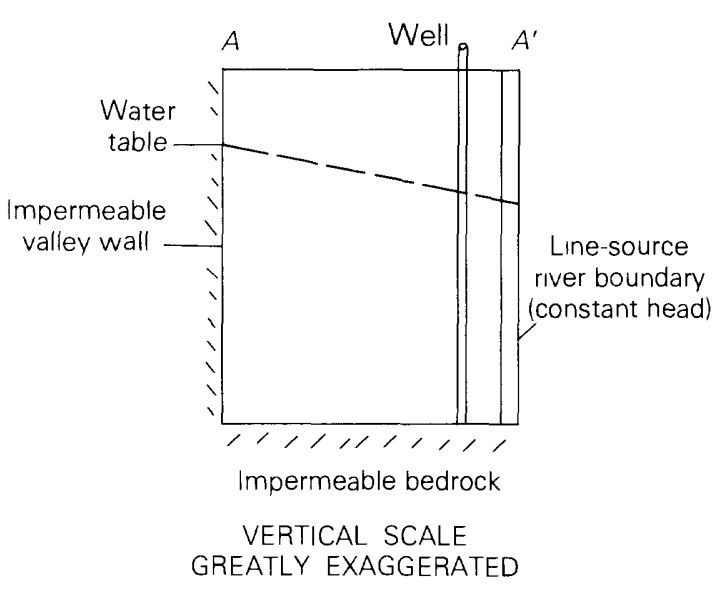

B. Cross-sectional view.

Figure 12. Idealized version of the aquifer for analysis with an analytical model using a linesource river boundary. $T$, aquifer transmissivity, and, $S$, specific yield.

The prepumping water levels shown in figure $13 \mathrm{~A}$ reflect all of the real-world features such as recharge from precipitation and upland areas and hydraulic properties of the aquifer. Steady-state drawdowns determined by using the analytical model, in which the river is treated as a constant head, are illustrated in figure $13 B$. The contributing area for the well and water table configuration that results when the drawdowns (fig. 13B) are superimposed on the prepumping water table (fig. 13A) are shown in figure $13 C$.
A comparison of figures $13 B$ and $13 C$ shows that the area of influence is much larger than the contributing area for the well. The area of influence and the contributing area determined by using this analytical model are limited to the well side of the river because of the way the river boundary has been simulated. A constant-head boundary acts as an unlimited source of water for the well and thus limits the spread of the cone of depression. Although this particular model does not indicate how much of the pumped water is obtained from the river, techniques are available for determining this quantity (Theis and Conover, 1963; Wilson, 1981).

The suitability of a given boundary condition for analytical model analysis of contributing areas depends upon actual field conditions. In a situation where a surfacewater body totally limits the spread of drawdown caused by a well, either because the surface water fully penetrates the aquifer or because of very high aquifer and streambed permeability, the use of a constant-head river boundary model will produce realistic results. However, if drawdowns caused by a well can extend beneath and beyond a surface-water body, the constant-head boundary model will predict an unrealistic contributing area. In typical New England river-valley aquifers, the river partially penetrates the aquifer and has semipermeable bottom deposits. If drawdowns caused by a well can extend beneath and beyond the river, then contributing areas for a well also can extend beneath and beyond the river. Therefore, if a constant-head river-boundary analytical model is used to estimate a contributing area under these conditions, areas on the opposite side of the river will be overlooked.

\section{Two-Dimensional Numerical-Model Analysis}

The two-dimensional finite-difference model for aquifer simulation developed by Trescott and others (1976) was used to simulate ground-water flow in the hypothetical aquifer. The computer code is written in FORTRAN language and has been adapted for use on a wide variety of computers. Computer codes developed by Prickett and Lonnquist (1971) and by Wilson (1980) can be used to accomplish the same type of analysis.

Numerical models allow the simulation of areal variations in the hydraulic properties of an aquifer, while analytical models are based on the assumption that hydraulic properties of an aquifer are uniform throughout the entire aquifer area. Numerical-model analysis requires that the aquifer area be divided (discretized) into small blocks. The hydraulic properties within each block are assumed to be uniform but may vary from block to block. The grid network used to discretize the hypothetical aquifer is shown in figure 14. The blocks are assumed to extend through the full saturated thickness of the aquifer and to have uniform areal dimensions of $200 \mathrm{ft}$ per side. The grid network is 


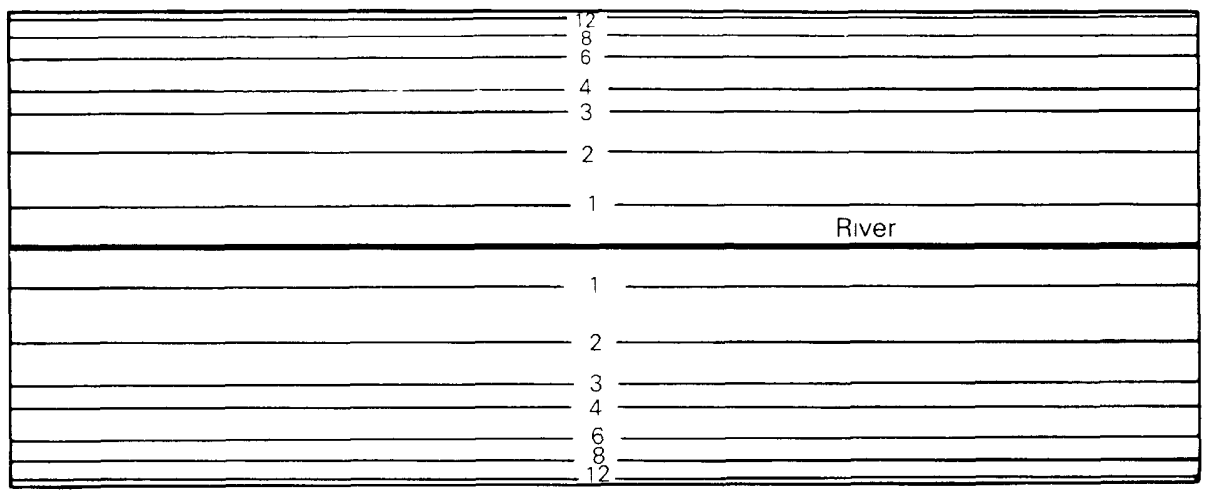

A

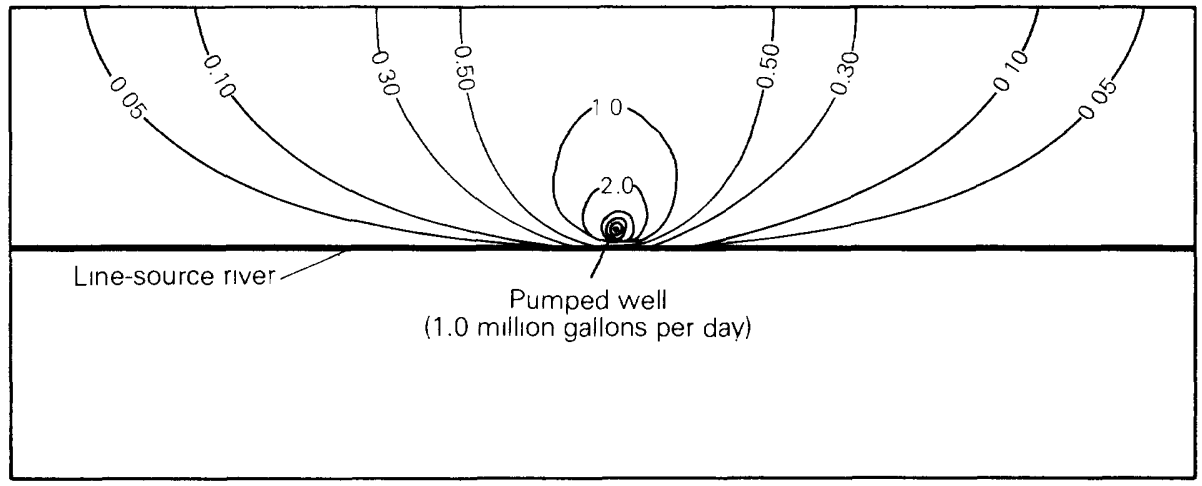

B

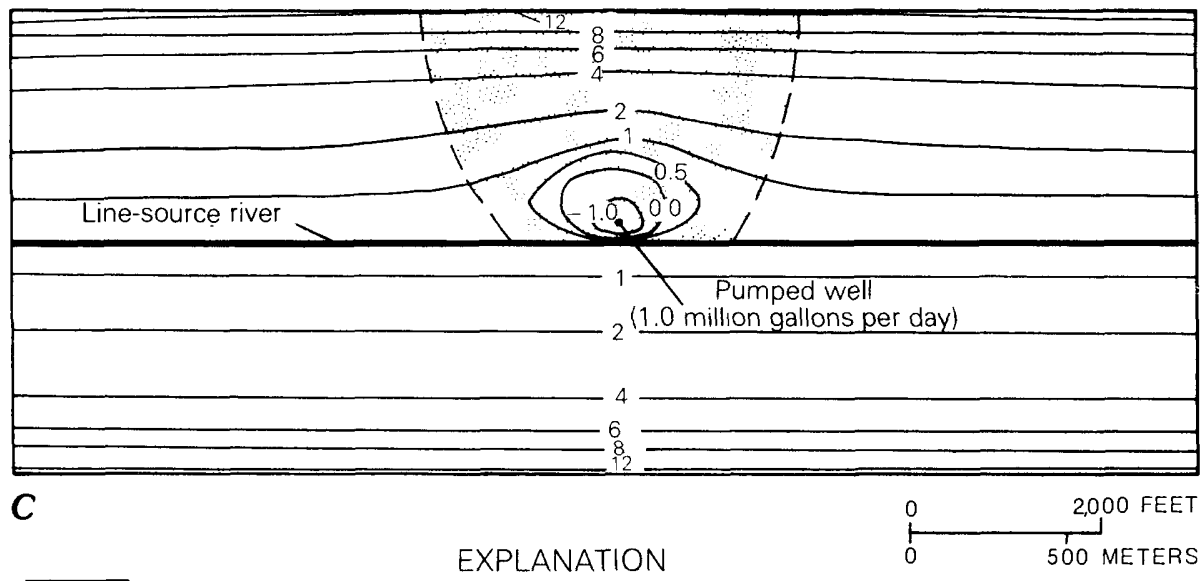

Contributing area

Equipotential line-Interval, in feet, is variable

For all figures, units of head and drawdown are expressed in feet relative to river stage

Figure 13. Idealized aquifer showing, $A$, Prepumping water-table altitudes; $B$, Drawdowns computed by using the analytical model; and, $C$, Water-table altitudes and contributing area resulting from superposition of $A$ and $B$ for the line-source river-boundary condition.

designed to cover the hypothetical aquifer from valley wall to valley wall $(5,000 \mathrm{ft})$ along a $12,000-\mathrm{ft}$ reach of valley. In the model, the contact between stratified drift and till beneath the aquifer was considered to be an imperme- able boundary. The flux across this boundary in real aquifer systems is assumed to be insignificant when compared to flow in the aquifer. The boundaries that terminate the extent of the aquifer along the valley axis (at each end of the 

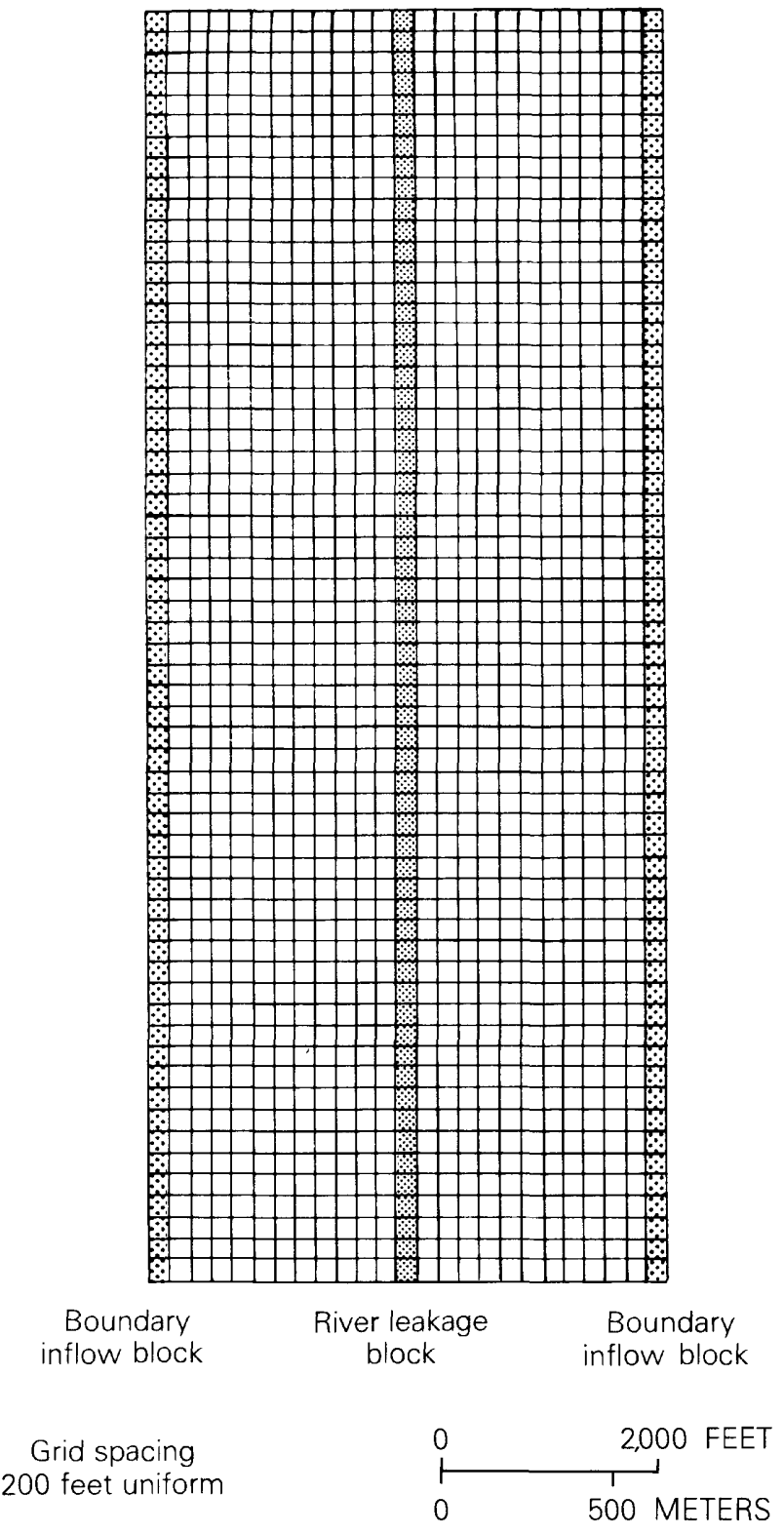

A. Plan view.

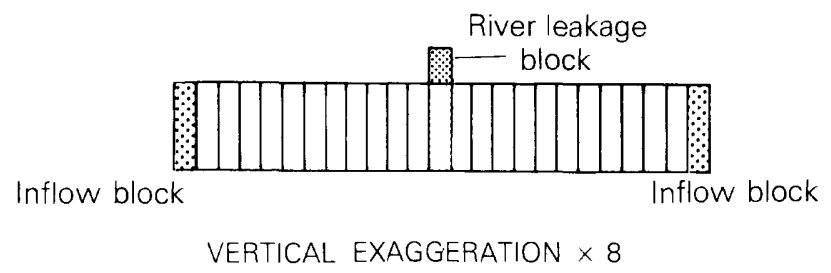

B. Cross-sectional view.

Figure 14. Finite-difference grid used for the twodimensional numerical-model analyses. aquifer) are treated as impermeable boundaries in the numerical model because they are parallel to flow lines. Under actual field conditions, flux across these boundaries could occur in response to drawdown caused by a pumping stress. Pumping wells in the numerical model of the aquifer were located far enough from these end boundaries so that drawdowns and changes in flow direction along them were minimal to nonexistent.

The lateral boundaries of the model, located along the aquifer-valley wall contact, were treated as constant flux boundaries to simulate inflow from the adjacent till uplands. Grid block locations, where boundary flux was simulated, are shown in figure 14. The amount of flux applied at each block was determined on the basis of the size of the adjacent upland drainage area and an estimated average annual runoff of $0.6(\mathrm{ft} / \mathrm{yr}) / \mathrm{mi}^{2}$. The total upland area adjacent to the aquifer was assumed to be $4 \mathrm{mi}^{2}, 2 \mathrm{mi}^{2}$ on each side of the valley. The upland area and the recharge along the boundary were distributed equally along each boundary block.

The river was treated as a head-dependent flux boundary to simulate flow between the river and the aquifer (fig. 14). Grid block locations where flux between the river and aquifer was simulated are shown in figure 14 . The river was assumed to be $200 \mathrm{ft}$ wide and $5 \mathrm{ft}$ deep and to have a flat gradient throughout the modeled area. The streambed deposits were assumed to be $2 \mathrm{ft}$ thick and to have a permeability of $2 \mathrm{ft} / \mathrm{d}$.

The assumption of a flat gradient combined with lateral-boundary flux causes ground-water contours in the aquifer to be exactly parallel to the river, a condition that usually does not exist in real aquifers. For the purposes of this study (the delineation of contributing areas), such assumed conditions are considered acceptable. However, under certain field conditions, the actual shape of contributing areas will be different from those illustrated (fig. 15).

Figure $15 \mathrm{~A}$ (same as fig. $9 \mathrm{C}$ ) shows the contributing area for a well pumping $0.25 \mathrm{Mgal} / \mathrm{d}$ from an aquifer in which the river gradient is minimal. The geohydrologic conditions for the aquifer are shown in figure 8 . The contributing area shown in figure $15 B$ was determined for the same aquifer except that the river has a gradient of 10 $\mathrm{ft} / \mathrm{mi}$. The effect that water-table configuration and river gradient have on the shape of the contributing area for the well is evident when figures $15 A$ and $15 B$ are compared. Despite the difference in shape, the contributing areas in figures $15 A$ and $15 B$ are equal in area.

The two-dimensional numerical model allows simulation of water-table conditions by adjusting aquifer transmissivity for changes in the saturated thickness of the aquifer. To accomplish this simulation, values of hydraulic conductivity, aquifer-bottom altitude, and starting watertable altitudes were assigned to each grid block in the model. In addition, recharge from precipitation was applied uniformly over each grid block in the model at the rate of 
Table 2. Average annual water budget for the hypothetical aquifer computed by using the two-dimensional numerical model

\begin{tabular}{|c|c|c|c|}
\hline \multicolumn{4}{|c|}{ Average annual water budget in cubic feet per second } \\
\hline $\ln$ & & Out & \\
\hline $\begin{array}{l}\text { Recharge from precipitation } \ldots \ldots \ldots \ldots \ldots \\
\text { lnflow from till uplands } \ldots \ldots \ldots \ldots \ldots \ldots\end{array}$ & $\begin{array}{l}3.4 \\
2.2\end{array}$ & Leakage to river................... & 5.6 \\
\hline$\ldots \ldots \ldots \ldots \ldots$ & 5.6 & Total out & 5.6 \\
\hline
\end{tabular}

$2 \mathrm{ft} / \mathrm{yr}$ (fig. 11). The model was run until steady-state conditions were reached (fig. 16). The resulting steady-state water-table conditions and the computed water budget (table 2) seem reasonable when compared with actual conditions found in the field. These results (fig. 16 and table 2) define the average long-term conditions for the

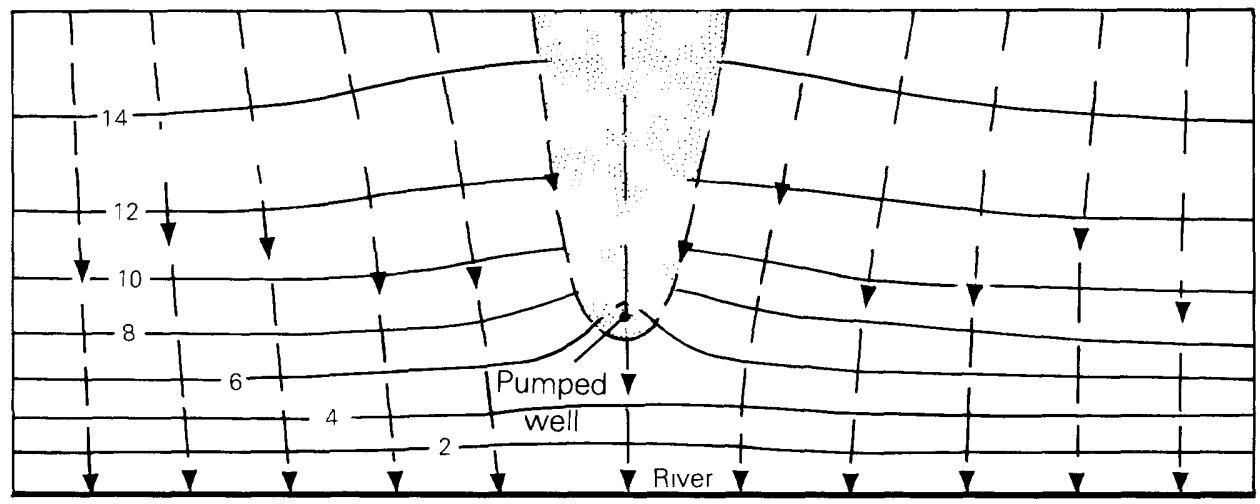

A. Flat gradient

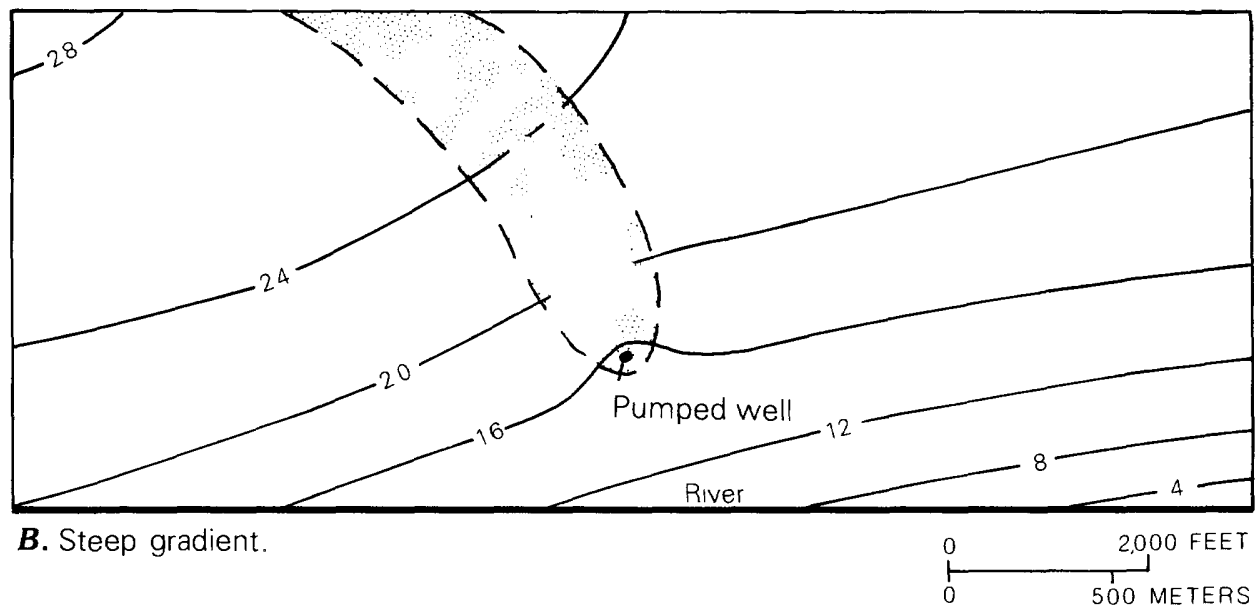

EXPLANATION

Contributing area

- 10 Equipotential line_-Interval, in feet, is variable

Units of head and drawdown are expressed in feet relative to river stage

Figure 15. Contributing areas for a well pumping 0.25 million gallons per day in a river-valley aquifer (shown in figure 8). 


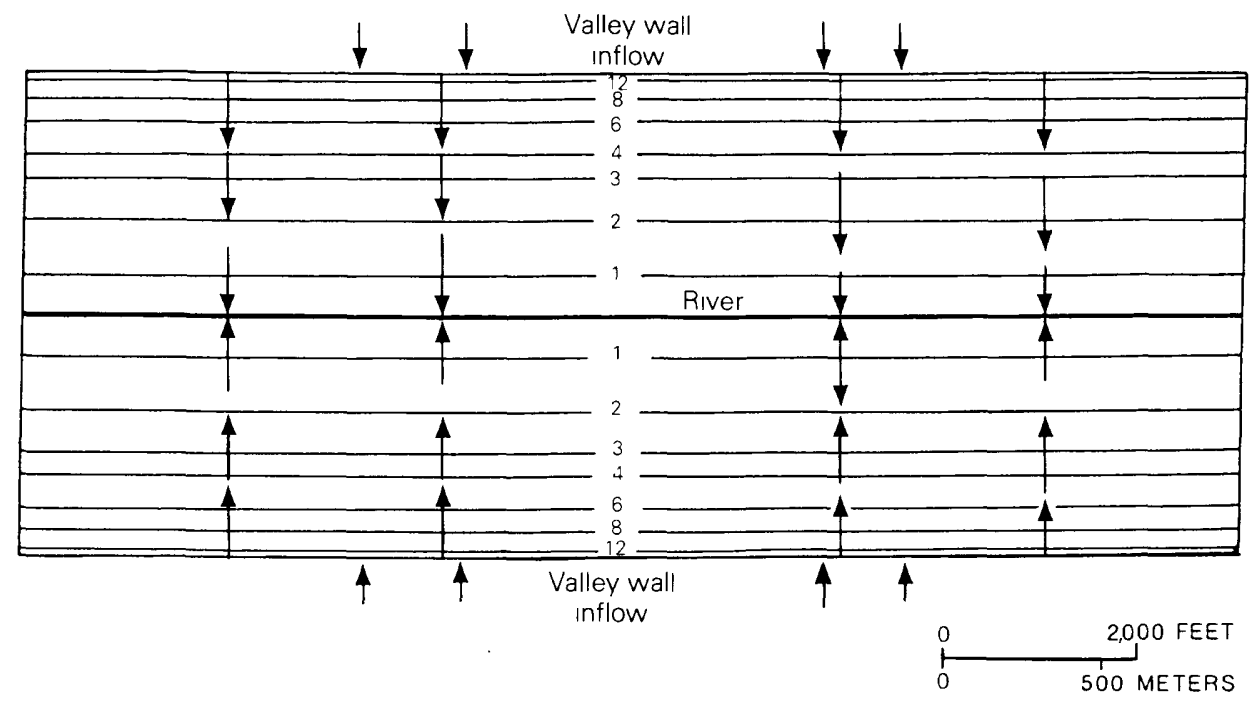

EXPLANATION

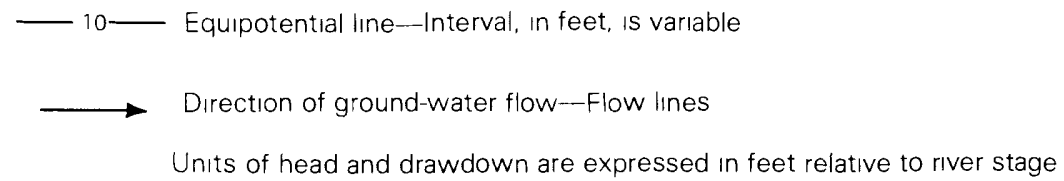

Figure 16. Average steady-state water-table altitudes, without pumping, computed by using the two-dimensional numerical model.

hypothetical aquifer and form the basis of comparison for the following examples in which the contributing area of a well will be estimated for various pumping rates, well locations, and aquifer hydraulic properties.

\section{Procedure for Contributing-Area Estimation}

To delineate the contributing area of a well by using the two-dimensional numerical model:

1. Introduce a pumping well into the prepumping steadystate model. Steady-state pumping conditions were used because they illustrate the maximum impact of a given stress.

2. Construct a flow net on the basis of the steady-state water- table altitudes computed by the model. For a flow net in homogeneous, isotropic media, the rules for graphic construction of flow nets are as follows: (a) flow lines and equipotential lines must intersect at right angles throughout the system; (b) equipotential lines must meet impermeable boundaries at right angles; and (c) equipotential lines must parallel constant-head boundaries.

3. Determine the flow lines that separate the regional flow field from the flow field created by the pumping well on the well side of the river.

4. Determine model grid blocks where induced infiltration occurs and tabulate the amount of total infiltration.

5. Construct dividing flow lines on the opposite side of the river perpendicular to water-table contours at grid block locations where ground-water flow passes under the river toward the pumping well.

6. Determine a water budget for the pumping well by summing the amount of recharge entering the contributing area for the well, including recharge from precipitation, influx through the valley wall boundaries, and induced infiltration.

7. Compare the amount of recharge entering the contributing area with the pumping rate as a check on the proper delineation of the contributing area. If the rates are not similar, an error is indicated. (In this study, if recharge into the contributing area was within \pm 5 percent of the pumping rate, the contributing area delineation was considered to be reasonable.)

\section{Application and Sensitivity Testing}

Variation in levels and patterns of stress affect the size and shape of the contributing area for a well in the hypothetical aquifer. The types of geohydrologic factors that can be simulated by using a two-dimensional model are well discharge, aquifer recharge, streambed permeability, aquifer hydraulic conductivity, and the proximity of a well to a source of induced infiltration.

\section{Well Discharge}

To demonstrate the effects that variations in well discharge rate have on the extent of the contributing area and the sources of water to a well, steady-state simulations 


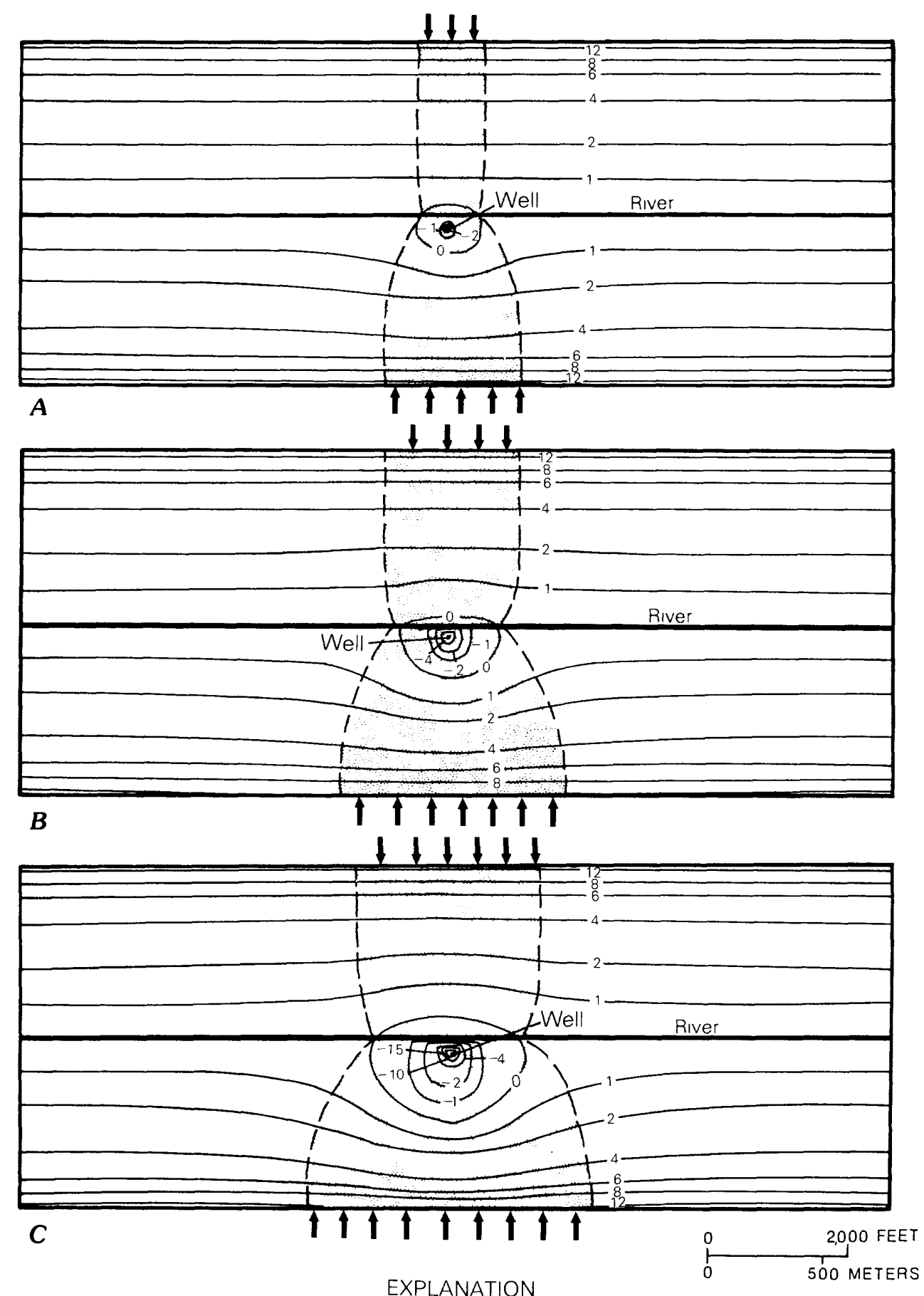

\footnotetext{
Contributıng area

$-10-$ Equipotential inne-Interval, in feet, is varıable

Recharge from till upland areas

For all figures, units of head and drawdown are expressed in feet relative to river stage
}

Figure 17. Water-table altitudes and contributing areas of a well pumped at, $A, 0.5 ; B, 1.0$; and, $C, 2.0$ million gallons per day. 
were run in which a well, located in the center of the aquifer and $200 \mathrm{ft}$ from the river, was pumped at rates of $0.5,1.0$, and $2.0 \mathrm{Mgal} / \mathrm{d}$ (fig. 17). These pumping rates are typical of those that occur in the field. The sources of water derived
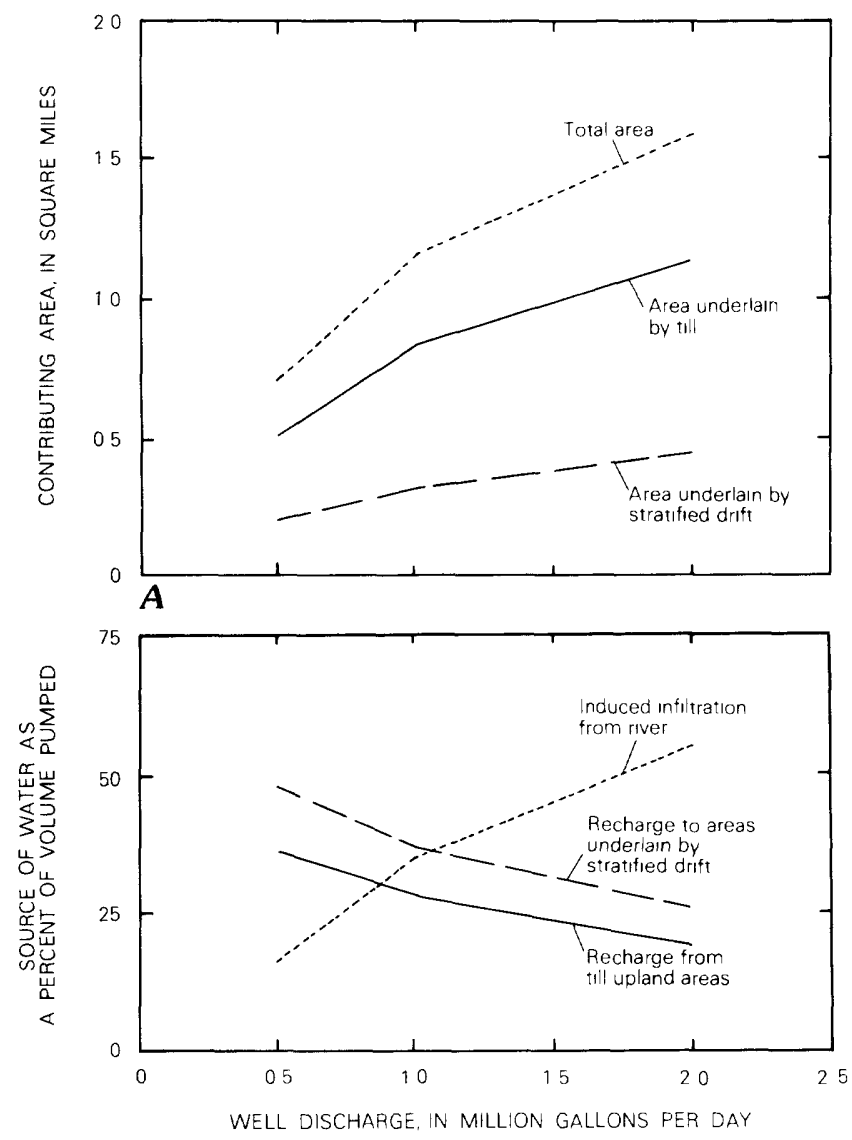

B

Figure 18. $A$, Sizes of contributing areas; and, $B$, Sources of water pumped from the well as a function of well discharge. by the well, as a percentage of total water pumped, and the sizes of contributing areas for different pumping rates are shown graphically in figure 18 .

When the pumping rate is increased from 0.5 to 2.0 $\mathrm{Mgal} / \mathrm{d}$, the total contributing area increases from 0.7 to 1.6 $\mathrm{mi}^{2}$. The total contributing area consists of areas underlain by till adjacent to the aquifer and stratified-drift aquifer areas. The drift areas can be determined directly from the steady-state water-table configurations shown in figure 17 . The sizes of contributing areas underlain by till adjacent to the aquifer are determined on the basis of the assumptions that recharge to till is $0.6(\mathrm{ft} / \mathrm{yr}) / \mathrm{mi}^{2}$; that $2 \mathrm{mi}^{2}$ of upland, underlain by till, border each side of the aquifer; and that this area and the resulting recharge are distributed evenly along the boundary of the aquifer.

Induced infiltration from the river increased from 16 to 55 percent of the water pumped by the well as the rate of withdrawal increased from 0.5 to $2.0 \mathrm{Mgal} / \mathrm{d}$. Conversely, the percentage of contribution from till and drift areas decreased from 84 to 45 percent of water pumped by the well over the same rates. In this sequence of examples, the contributing area increased by a factor of about two, and the amount of induced infiltration increased by a factor of about three when pumping increased by a factor of four.

Several important observations about the delineation of contributing areas of a pumping well can be made from the foregoing analyses:

1. The maximum expected yield for a well or well field must be known to properly delineate the contributing area because changes in the well-discharge rate can cause significant change in the size of the contributing area and in the sources of water pumped by a well.

2. If induced infiltration of surface water occurs, protection of contributing areas alone will not be sufficient to ensure good water quality at the well.

3. Source areas for a well can extend beneath and beyond a river that acts as a source of infiltration and include adjacent upland areas on both sides of the valley.

Table 3. Summary of ground-water-protection areas for municipal-supply wells in New England

\begin{tabular}{|c|c|c|}
\hline State & $\begin{array}{l}\text { Protection } \\
\text { area } \\
\text { radius }\end{array}$ & Remarks \\
\hline Connecticut & $200 \mathrm{ft}$ & For wells discharging $>50 \mathrm{gal} / \mathrm{min}^{1}$ \\
\hline Maine ............. & $300-400 \mathrm{ft}$ & Engineering report required for each new municipal well. ${ }^{2}$ \\
\hline Massachusetts & $400 \mathrm{ft}$ & For wells pumping $1.0 \mathrm{Mgal} / \mathrm{d}^{3}$ \\
\hline New Hampshire & $400 \mathrm{ft}$ & Protective radius for bacteriological contaminants. ${ }^{4}$ \\
\hline Rhode Island ... & $400 \mathrm{ft}$ & Recommended distance for gravel packed wells. ${ }^{5}$ \\
\hline Vermont .... & $\begin{array}{l}200 \mathrm{ft} \\
\text { or APA }\end{array}$ & $\begin{array}{l}\text { Aquifer protection areas (APA) ranging in size from } 4 \text { to } 2,600 \text { acres have been } \\
\text { estimated for } 209 \text { municipal wells in Vermont. }\end{array}$ \\
\hline
\end{tabular}

\footnotetext{
${ }^{1}$ Connecticut Public Health Code 19-13-B51, Water supply regulations.

${ }^{2}$ Maine State Health Code 10-144A, Rules related to drinking water.

${ }^{3}$ Commonwealth of Massachusetts, Department of Environmental Quality Engineering, Guidelines for public water systems.

${ }^{4}$ New Hampshire Water Supply and Pollution Control Commission Guidelines WS 309.04 and 309.5, Drinking water regulations, 1984.

${ }^{5}$ Rhode Island, Rules and regulations pertaining to public drinking water, R46-13 DWS Section 3.0.

${ }^{6}$ Vermont Aquifer protection area reference document, March 1983.
} 
4. Contributing areas estimated for wells in the hypothetical aquifer are much different in shape than the simple circular drawdown or formula areas typically used for ground-water protection.

5. The size of contributing areas estimated for wells in the hypothetical aquifer are much larger than the areas historically determined for bacteriological or sanitary ground-water protection around wells in New England.

Table 3 is a summary of the areas currently used for ground-water protection around municipal-supply wells in sand and gravel aquifers in the New England States.

\section{Aquifer Recharge}

Variations in the recharge rate to an aquifer can occur for several reasons, including natural seasonal fluctuations in precipitation and evapotranspiration, longer term climatic changes, or urbanization. Resulting changes in water levels and ground-water flow will affect the contributing area to a well. To illustrate these effects, a series of simulations was run in which recharge to the hypothetical aquifer was varied.

Steady-state simulations were made in which the average rate of recharge from precipitation of $2 \mathrm{ft} / \mathrm{yr}$ was varied by factors of 0.5 and 1.5 , and proportional changes were made in the rate of recharge from areas underlain by till adjacent to the aquifer (fig. 19). These values represent the approximate expected range in rates of the average annual recharge to stratified-drift aquifers in New England. In addition, to imitate an extreme drought condition, a simulation was made of a 6-month period in which all recharge ceased and the river dried up. In all of these simulations, the well was located $200 \mathrm{ft}$ from the river in the center of the aquifer and pumped at a rate of $1.0 \mathrm{Mgal} / \mathrm{d}$.

Variations in the average annual recharge rate cause a change in the amount of water flowing through the hypothetical aquifer and in the ground-water gradient from the valley wall to the river. When recharge is at a maximum (1.5 times the average), the ambient flow and gradient are greatest, and the total contributing area for the well is 0.9 $\mathrm{mi}^{2}$. When average annual recharge is at a minimum $(0.5$ times the average), the ambient flow and gradient are least, and the contributing area for the well is $1.7 \mathrm{mi}^{2}$.

The sources of water to the well also change as the recharge rate is varied (fig. 20). When recharge is at a maximum, induced infiltration makes up 26 percent of pumped water. At the minimum recharge rate, induced infiltration is 56 percent of the pumped water. When less water is available from recharge (that is, a decrease in recharge from precipitation and inflow from till-covered areas adjacent to the aquifer), the contributing area grows, and induced infiltration increased to make up for the deficit.

An assumption for the simulations discussed above is that the river never goes dry so that water is always available for induced infiltration. Depending on hydrologic conditions in an actual basin, minimum recharge conditions could cause surface waters to dry up for extended periods; therefore, without a source of induced infiltration, the contributing area to a well would increase in size to make up the deficit.

A 180-day transient simulation of the hypothetical aquifer was designed to illustrate the extreme drought condition in which the surface water dries up. Recharge from precipitation and inflow from areas underlain by till adjacent to the aquifer were set equal to zero. The model was modified so that ground water could flow from the aquifer to the river but not in the opposite direction. This modification was designed to imitate a condition where evapotranspiration along the river (the area where the water table is closest to land surface) causes ground water to flow toward the river but not in sufficient amount to sustain surface flow.

The steady-state water-table altitudes computed for the minimum average annual recharge condition (fig. 19A) were used for initial conditions. During the 180-day transient-simulation period, water levels decline steadily as ground water moves from storage to the well and river area. The water-table configurations and contributing areas for the well after 30,90, and 180 days are shown in figure 21 . From the initial size of $0.9 \mathrm{mi}^{2}$, the contributing area grows to a maximum of $1.7 \mathrm{mi}^{2}$ during 180 days of drought. After 180 days, the well diverts flow from practically the entire area of the aquifer. (The method of simulation did not account for storage in upland areas, thereby causing the estimated contributing area in stratified drift to be larger than it might actually be.)

When induced infiltration makes up a large proportion of pumped water, the contributing area is larger on the well side of the river than on the opposite side of the river. The extreme case, where the contributing area was limited to the well side of the river, is illustrated in figure 13. The shapes of the contributing areas shown in figure 21 reflect the lack of induced infiltration as they extend across the entire valley and are almost symmetrical along the axis of the river.

\section{Streambed Permeability}

The river boundary in the model can act as a source of recharge to ground water or as a sink for ground-water discharge. Under nonpumping conditions, the river acts as the discharge point for ground water throughout the aquifer. When pumping lowers the ground-water level below the river stage, natural-flow directions in the vicinity of the well are reversed and surface water flows into the aquifer. If the aquifer head falls below the elevation of the stream bottom, flow from the river will reach a maximum steady rate provided all other factors, such as river stage and water temperature, remain the same.

Flow through the streambed can be expressed as a form of Darcy's law (see Prickett and Lonnquist, 1971, 


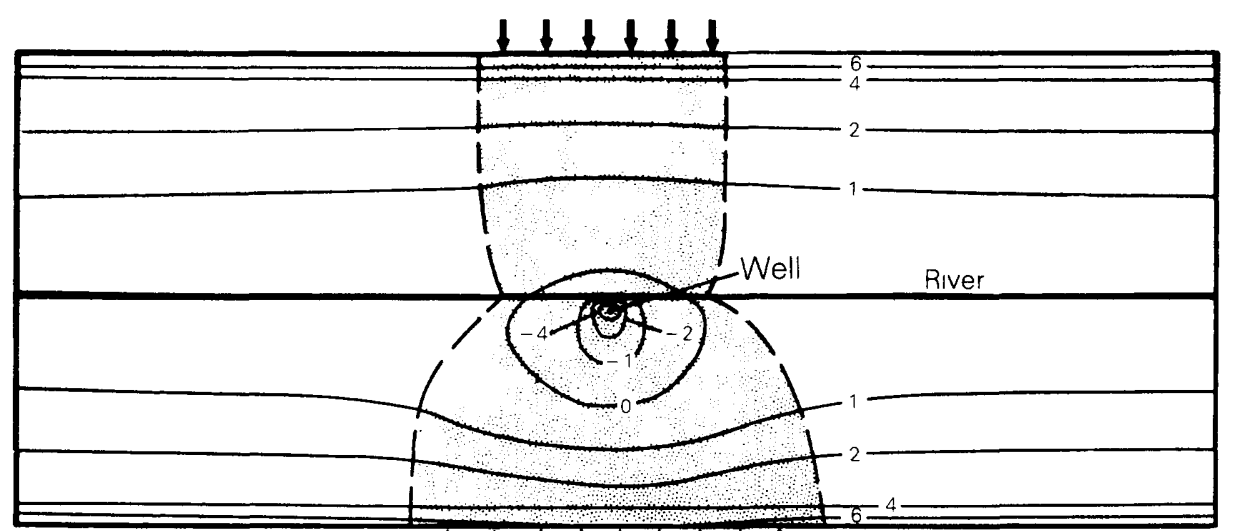

A

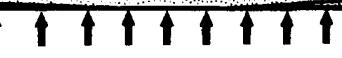

$1+1+1$

B

$1+1$

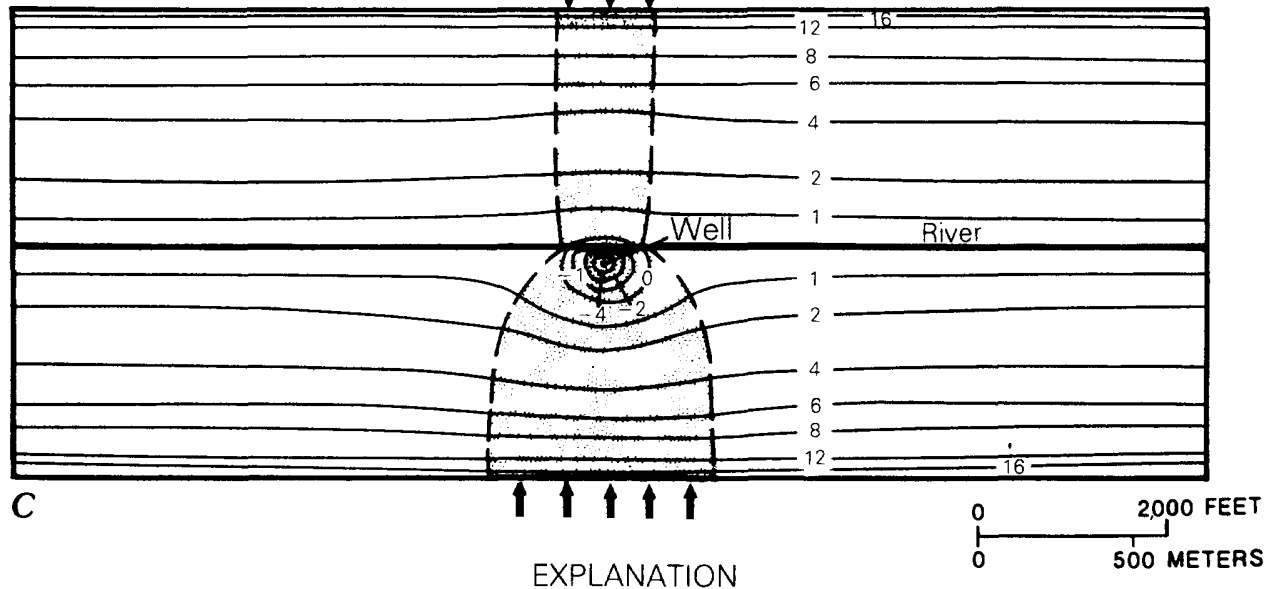

Contributing area

- 12 - Equipotentıal lıne_-Interval, in feet, is variable

$\rightarrow \quad$ Recharge from till upland areas

For all figures, units of head and drawdown are expressed in feet relative to river stage

Figure 19. Water-table altitudes and contributing areas of a well pumped at 1.0 million gallons per day for, A, 0.5 times average; $B$, Average; and, $C, 1.5$ times average recharge. 

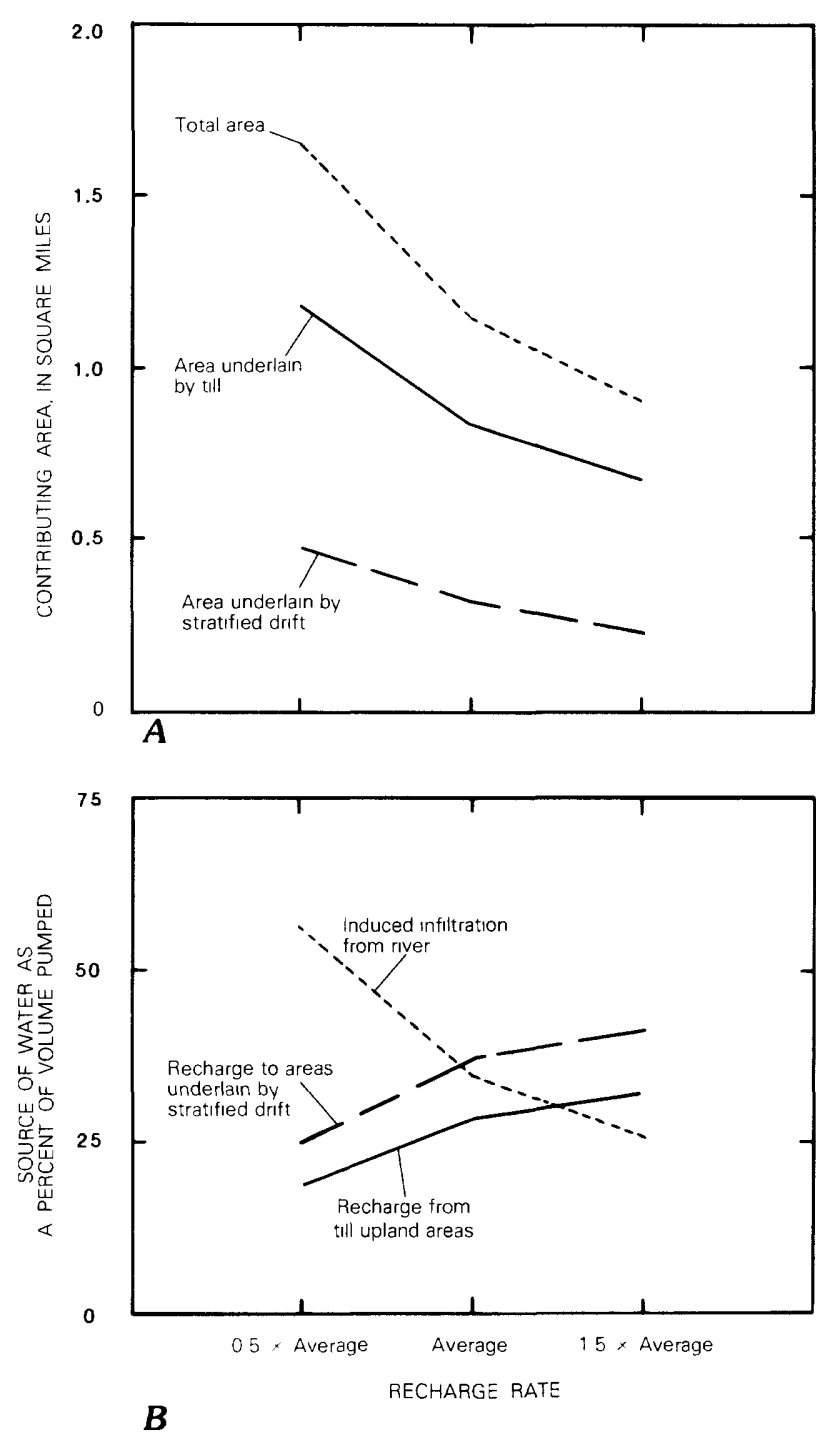

Figure 20. $A$, Sizes of contributing areas; and, $B$, Sources of water pumped from the well as a function of recharge rate.

p. 33; Trescott and others, 1976, p. 4; McDonald and Harbaugh, 1984, p. 209):

$$
Q^{\prime}=\left(k^{\prime} / b^{\prime}\right) A\left(h^{\prime}-h\right)
$$

where:

$Q^{\prime}=$ infiltration rate through the streambed, in cubic feet per second;

$k^{\prime}=$ vertical hydraulic conductivity of the streambed, in feet per second;

$b^{\prime}=$ streambed thickness, in feet;

$A=$ streambed area, in feet squared;

$h^{\prime}=$ river stage, in feet; and

$h=$ ground-water altitude immediately below the streambed, in feet.

To simulate a leaky streambed in the numerical model, values for each of the parameters on the right hand side of the equation must be determined. Streambed permeability $\left(k^{\prime}\right)$ and streambed thickness $\left(b^{\prime}\right)$ are difficult to measure. Efforts have been made to measure these parameters in the field (Rosenshein and others, 1968; Haeni, 1978), but they are often estimated from published values or during model calibration. Also, streambed permeability and thickness can vary naturally in time because of scouring floods or sedimentation.

To test the effect of variation in streambed permeability on the size of the contributing area of a well pumping $1.0 \mathrm{Mgal} / \mathrm{d}$, a series of simulations was run in which the ratio of streambed permeability to thickness $\left(k^{\prime} / b^{\prime}\right)$ was set at $0.1,1.0$, and 10 (fig. 22). This variation was assumed to cover the range of reasonably expected values.

Variations in $k^{\prime} / b^{\prime}$ cause changes in the water-table gradient from the valley wall to the river throughout the modeled area. The maximum head difference from the valley wall to the river during pumping is $13.1 \mathrm{ft}$ when $k^{\prime} / b^{\prime}$ is $0.1,11.8 \mathrm{ft}$ when $k^{\prime} / b^{\prime}$ is 1.0 , and $11.6 \mathrm{ft}$ when $k^{\prime} / b^{\prime}$ is 10.0 .

Varying $k^{\prime} / b^{\prime}$ causes substantial variation in the rate of induced infiltration from the river and consequently in the size of contributing areas, as shown in figure 23. When $k^{\prime} / b^{\prime}$ is a minimum $(0.10)$, induced infiltration provides only 8 percent of pumped water, and the total contributing area covers $1.8 \mathrm{mi}^{2}$. When $k^{\prime} / b^{\prime}$ is a maximum (10.0), induced infiltration makes up 45 percent of pumped water, and the total contributing area is $0.9 \mathrm{mi}^{2}$.

\section{Aquifer Hydraulic Conductivity}

One of the hydraulic properties of the aquifer that must be assigned to each grid block in the model is aquifer hydraulic conductivity. Hydraulic conductivity is not a well-known parameter and often is estimated during model calibration. In a typical glacial-drift aquifer, hydraulic conductivity values can vary by an order of magnitude or more.

To test the effects of variations in aquifer hydraulic conductivity, average values for the aquifer were increased by a factor of 3 and decreased by a factor of 0.3 (figs. 24 , 25 ). When the hydraulic conductivity is at the maximum ( 3 times the average) for this simulation, the contributing area is largest $\left(1.3 \mathrm{mi}^{2}\right.$, fig. $\left.24 \mathrm{C}\right)$. The predominant sources of water pumped from the well are areal recharge to stratified drift and recharge from areas underlain by till adjacent to the aquifer (fig. $25 B$ ). When the hydraulic conductivity is at the minimum ( 0.3 times the average), the contributing area is smallest $\left(1.0 \mathrm{mi}^{2}\right)$, and the major source of pumped water is induced infiltration from the river (fig. 25B).

Decreasing the average hydraulic conductivity by a factor of 0.3 has a greater effect on the size of the contributing area and sources of pumped water (fig. 25) than an equivalent increase. Changing the hydraulic conductivity of the aquifer by one order of magnitude, from 0.3 times the average to 3.0 times the average, causes a 


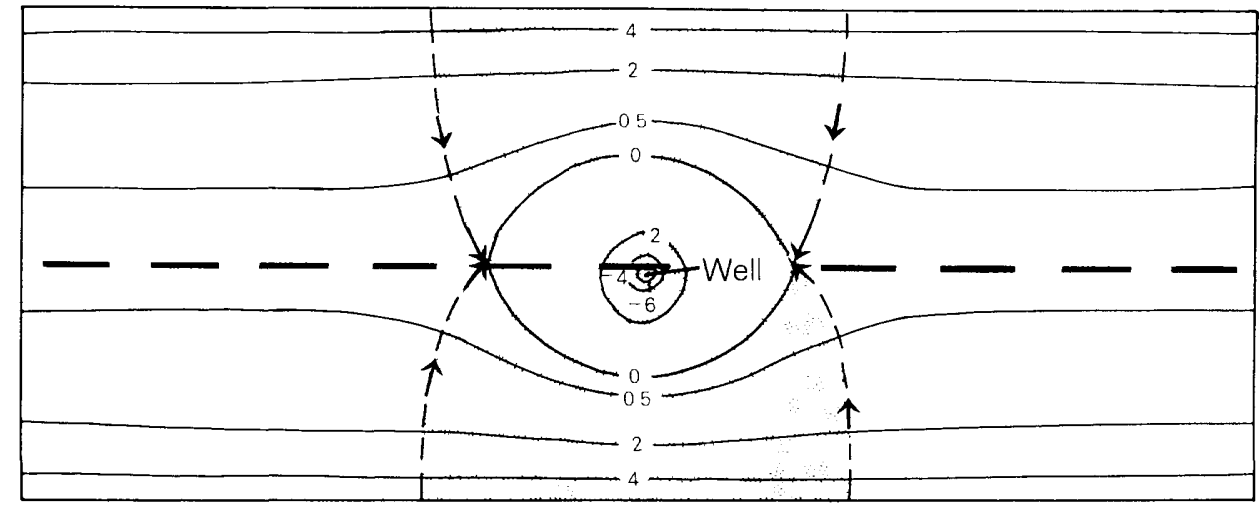

A. 30 days.

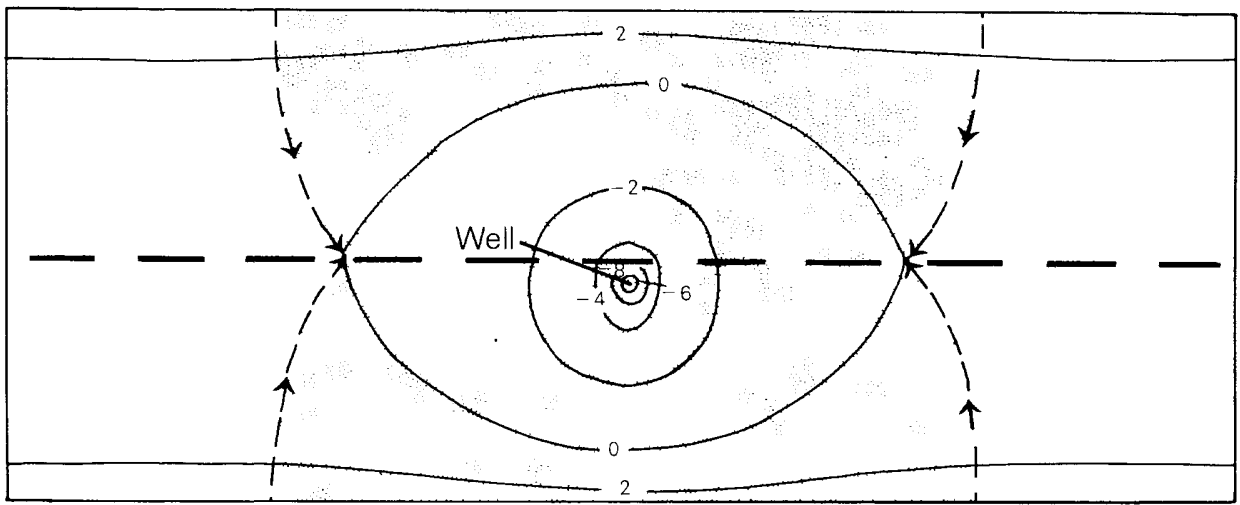

B. 90 days.

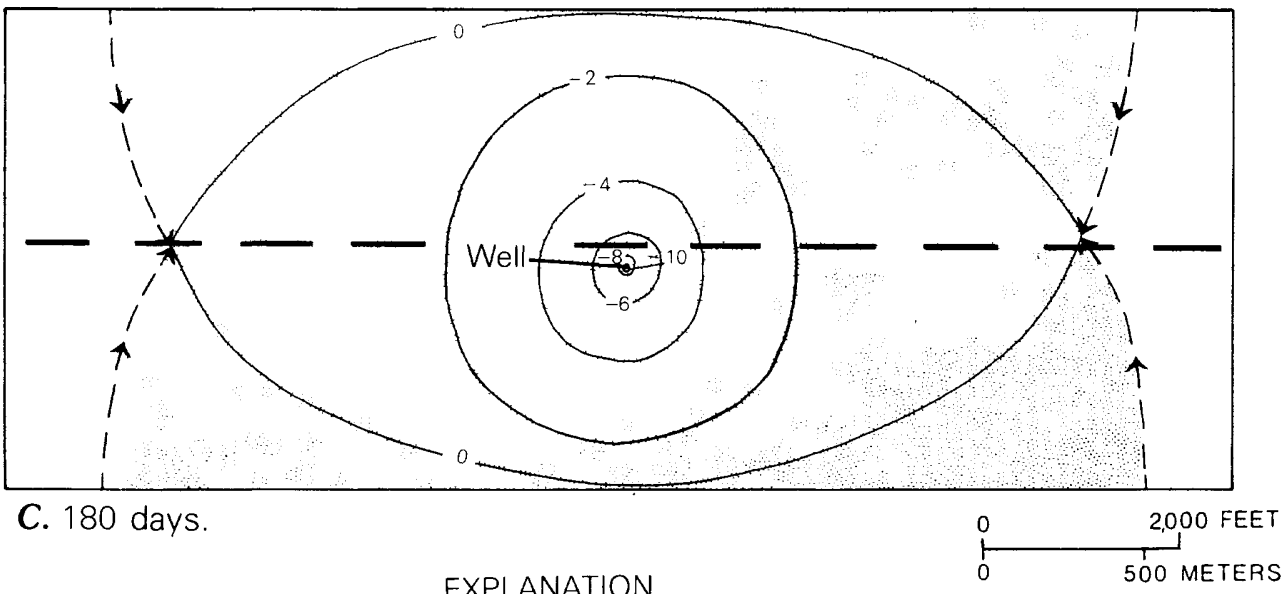

EXPLANATION

$\because \because \quad$ Contributing area

-10-Equipotential line-Interval, in feet, is variable

$\longrightarrow$ Direction of ground-water flow-Flow lines

Location of dried-up river bed

For all figures, units of head and drawdown are expressed in feet relative to river stage

Figure 21. Water-table configuration and contributing area of a well pumped at 1.0 million gallons per day after, $A, 30 ; B, 90$; and, $C, 180$ days of drought. 


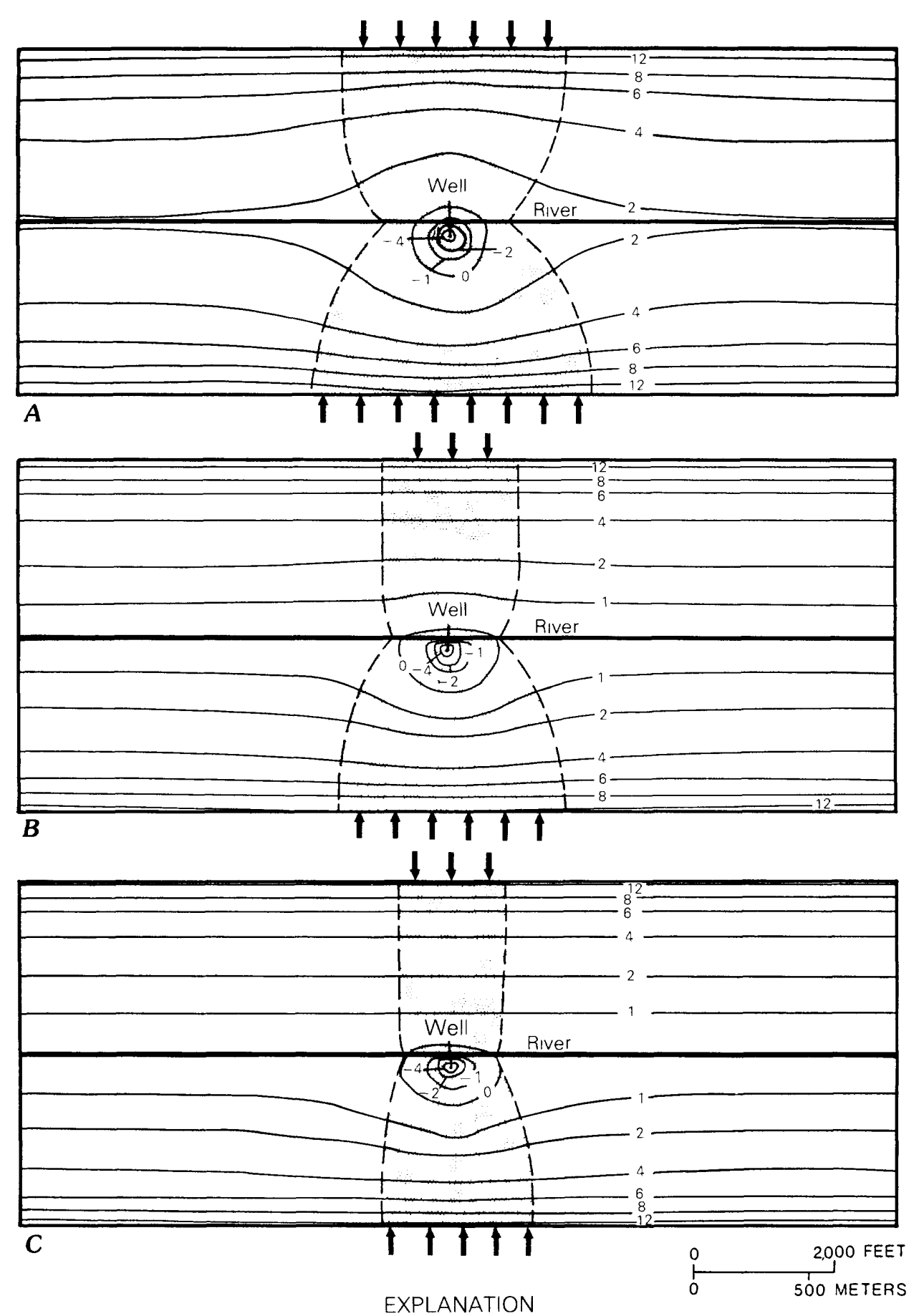

Contributing area

\footnotetext{
-10 - Equipotential line--Interval, in feet, is variable

$\rightarrow \quad$ Recharge from till upland areas

For all figures, units of head and drawdown are expressed in feet relative to river stage
}

Figure 22. Water-table altitudes and contributing areas of a well pumped at 1.0 million gallons per day and having streambed coefficients $\left(k^{\prime} / b^{\prime}\right)$ of, $A, 0.1 ; B, 1.0 ;$ and, $C, 10.0$. $k^{\prime}$, streambed hydraulic conductivity, in feet per day, and, $b^{\prime}$, streambed thickness, in feet. 

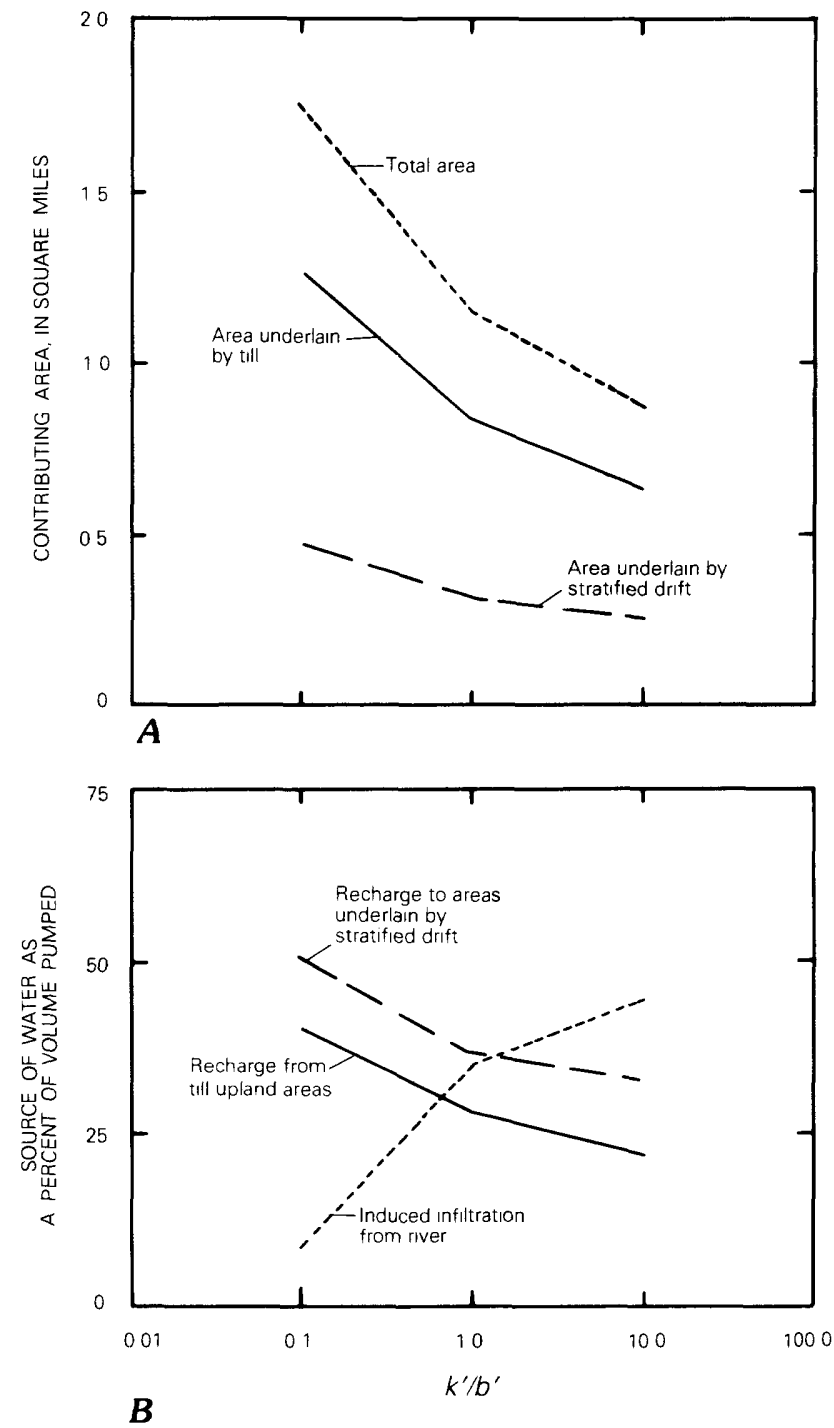

Figure 23. $\quad A$, Sizes of contributing areas; and, $B$, Sources of water pumped from the well as a function of streambed coefficient $\left(k^{\prime} / b^{\prime}\right) . k^{\prime}$, streambed hydraulic conductivity, in feet per day, and, $b^{\prime}$, streambed thickness, in feet.

44-percent increase in the size of the area that contributes water to the well and a decrease in the amount of induced infiltration from 44 to 26 percent of the water pumped from the well. Variations in aquifer hydraulic conductivity other than the uniform changes used in this analysis could also affect the sizes and shapes of contributing areas. A well located in a linear coarse-grained deposit surrounded by fine-grained materials (for example, an esker in lacustrine or marine deposits) could have a contributing area that has a much different shape than those illustrated here. The presence of discontinuous layers of low hydraulic conductivity (silt or clay) also could change the size and distort the shape of a contributing area. The numerical models can be used to simulate such complicated patterns of hydraulic conductivity in two or three dimensions.
Proximity of the Well to a River

All of the previous simulations have shown that induced infiltration from the river is an important factor to consider when delineating a contributing area in a typical glacial-drift, river-valley aquifer. In all of the previous simulations, the well was located $200 \mathrm{ft}$ from the river, a distance that is common in the field, but how is the quantity of induced infiltration affected if the well is located at greater distances from the river?

Mazzaferro (1989) delineated contributing areas for a well located 1,500 ft from a river that had a leaky streambed similar to that used in the hypothetical aquifer in this study. In most of the simulations, a ground-water divide between the well and the river prevented induced infiltration from the river. The source of water to the well in Mazzaferro's hypothetical model was ground-water capture (reduced discharge to the river on the well side of the river).

To investigate how proximity of the well to the river affects the contributing area for a well, a series of simulations was made in which a well pumping $0.5 \mathrm{Mgal} / \mathrm{d}$ was located 200,600 , and $1,400 \mathrm{ft}$ from the river. When the well is located $200 \mathrm{ft}$ from the river, induced infiltration makes up 16 percent of the pumped water, and the total contributing area is $0.7 \mathrm{mi}^{2}$ (fig. 26A). When the well is located $600 \mathrm{ft}$ from the river, pumped water is derived entirely from captured flow in the aquifer (fig. 26B). Some of the captured flow is from the opposite side of the river, but determining the exact shape of this area is difficult. When the well is located $1,400 \mathrm{ft}$ from the river (fig. $26 C$ ), there is no induced infiltration and no contribution from the opposite side of the river. In this case, the total contributing area is $0.98 \mathrm{mi}^{2}, 0.24 \mathrm{mi}^{2}$ in stratified drift and $0.74 \mathrm{mi}^{2}$ in till. Water pumped by the well is derived entirely from ground-water flow that is captured before discharging to the river. The ultimate source of this ground-water flow is areal recharge from precipitation on the stratified-drift aquifer and recharge to the aquifer from areas underlain by till adjacent to the aquifer.

Despite the fact that no induced infiltration occurs when the well is located $1,400 \mathrm{ft}$ from the river (fig. 26C), there is still an impact on streamflow because the well captures ground-water flow that normally would discharge to the river. Actually, streamflow is depleted by an amount equal to that pumped from the well, as in all of the simulations previously discussed. A well pumping 1.0 $\mathrm{Mgal} / \mathrm{d}$ reduces streamflow by that same amount during long-term pumping conditions, no matter how much of the water is derived from induced infiltration.

\section{Transient Simulation}

All of the parameter testing discussed thus far used steady-state simulations (with the exception of the drought simulation) so that the maximum effects of pumping, under a given set of hydrologic conditions, could be observed. As 

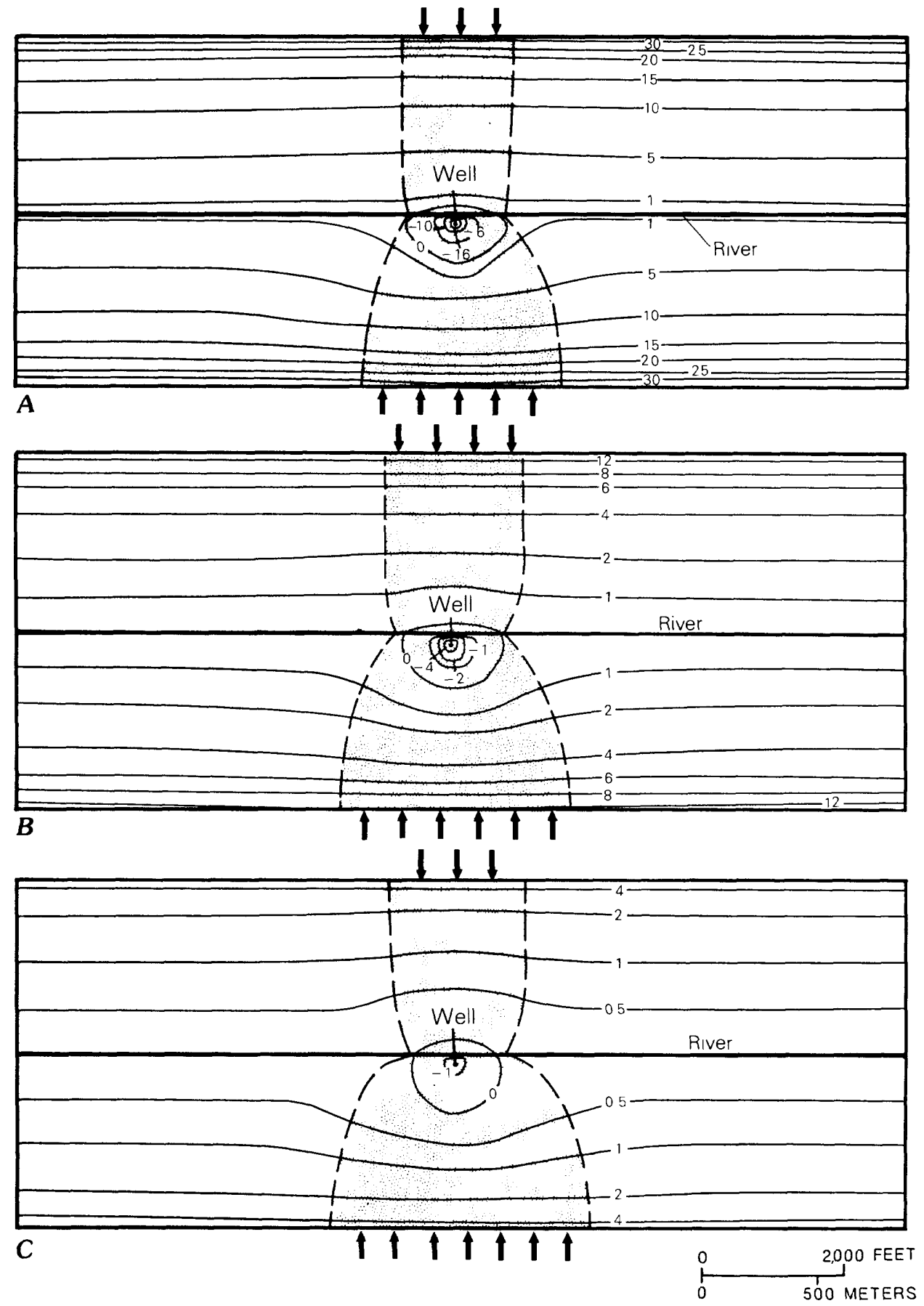

EXPLANATION

Contributing area

- 10 - Equipotential Ine-Interval, in feet, Is variable

Recharge from till upland areas

For all figures, units of head and drawdown are expressed in feet relative to river stage

Figure 24. Water-table altitudes and contributing areas of a well pumped at 1.0 million gallons per day for, $A, 0.3$ times average; $B$, Average; and, $C, 3.0$ times average hydraulic conductivity. 

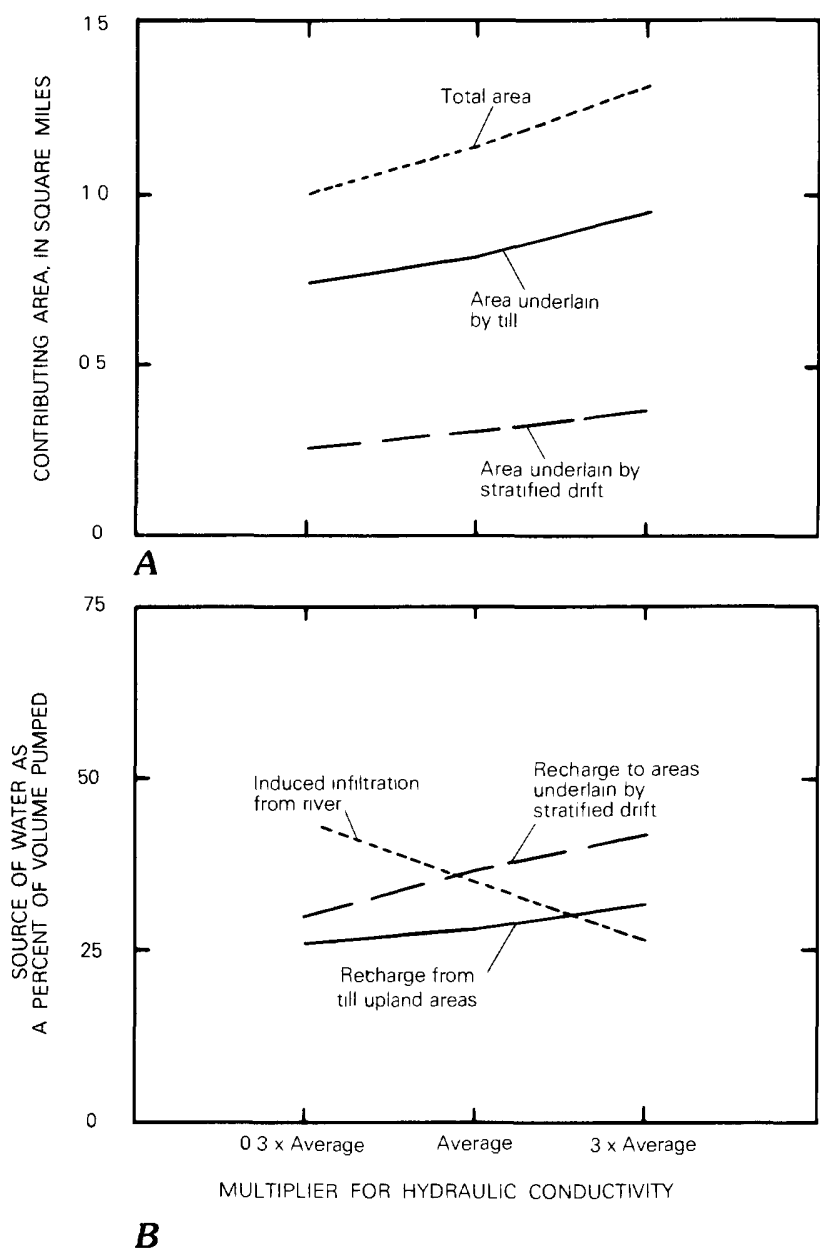

Figure 25. $A$, Sizes of contributing areas; and, $B$, Sources of water pumped from the well as a function of aquifer hydraulic conductivity.

a result, nothing was learned about the transient response of the aquifer. To determine low long it takes the hypothetical aquifer to reach equilibrium conditions after pumping begins, a 3-year transient simulation was conducted.

For the transient simulation, average aquifer hydraulic parameters and recharge rates were specified. The well was located in the standard position, $200 \mathrm{ft}$ from the river in the center of the aquifer, and pumping was $1.0 \mathrm{Mgal} / \mathrm{d}$. A storage coefficient of 0.2 was specified over the modeled area.

Sources of water derived by the well as a function of time (fig. 27) are categorized as storage depletion, captured discharge (flow from till and drift captured before discharging to the river), and induced infiltration from the river. Early in pumping ( 1 hour or less), all of the pumped water is from depletion of storage in the vicinity of the well. Subsequently, the well begins to capture ground water flowing through the aquifer before the water reaches the stream. When approximately 9 hours have elapsed, induced infiltration from the river begins. Storage depletion remains the primary source of pumped water until about 5 days have passed, after which captured discharge becomes the primary source of water to the well.

Induced infiltration closely approaches a maximum rate after about 40 days. Equilibrium conditions are established in the aquifer after about 365 days. At equilibrium, water is no longer being removed from storage, and pumped water is obtained from induced infiltration and captured ground-water discharge. If the pumping well were located at a greater distance from the river, a longer amount of time would be required for the aquifer to reach equilibrium conditions in response to pumping. At equilibrium, the proportion of captured ground-water discharge would increase, and induced infiltration from the stream would decrease compared to the relations depicted in figure 27 .

\section{Three-Dimensional Numerical-Model Analysis}

One of the essential assumptions inherent in the use of the two-dimensional model is that the predominant direction of flow in an aquifer is horizontal. For most thin stratified-drift aquifers, this assumption is true except in recharge or discharge areas. In the hypothetical aquifer, vertical flow is probably most significant near the leaky streambed and near the well. A three-dimensional flow model of the hypothetical aquifer was constructed to improve delineation of flow patterns beneath and beyond the streambed and to determine the effects of vertical anisotropy and partial well penetration on contributing areas.

The numerical model used to simulate threedimensional flow of ground water in the hypothetical aquifer was developed by McDonald and Harbaugh (1984). The model uses a finite-difference numerical method to solve the three-dimensional flow equation. In addition to the many options available in the two-dimensional model, a three-dimensional code allows simulation of vertical flow components between adjacent aquifer units. The units may or may not be separated by confining layers. Furthermore, the model simulates leakage to or from the aquifer through a leaky streambed in any model layer; the layers may be confined, unconfined, or a combination; and recharge may be applied to any model layer.

\section{Application and Sensitivity Testing}

The three-dimensional model of the hypothetical aquifer is essentially the same as the two-dimensional model with respect to hydraulic properties and rechargedischarge relations, except that the three-dimensional model is divided vertically into five layers. The finite-difference grid used in the three-dimensional simulation is shown in plan and cross-sectional views in figure 28. Layer one of the three-dimensional model (top layer) has the same areal extent as the two-dimensional model (fig. 14A), but the 

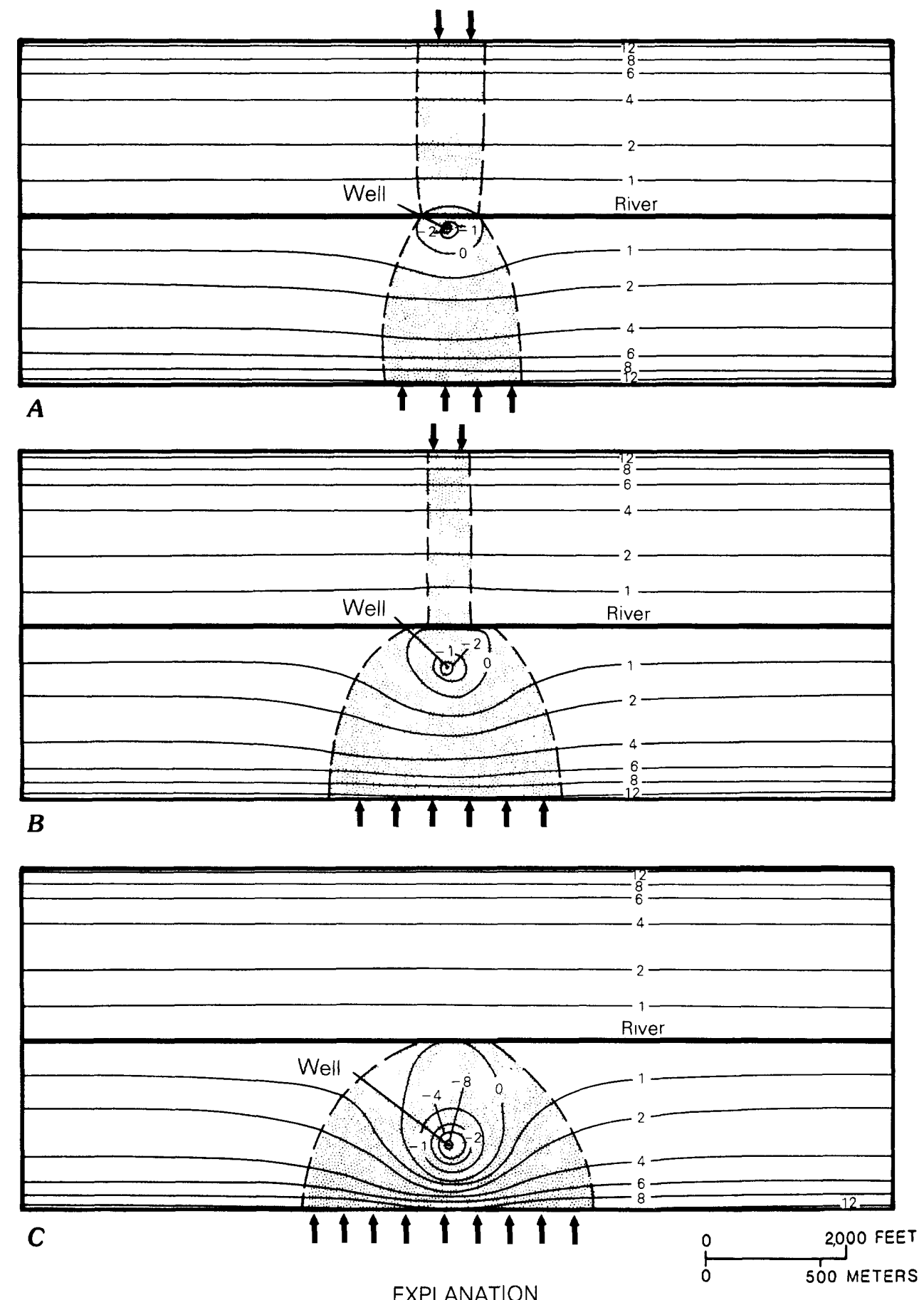

\footnotetext{
Contributıng area

- 10 - Equipotential line--Interval, in feet, is varıable

$\rightarrow$ Recharge from till upland areas

For all figures, units of head and drawdown are expressed in feet relative to river stage
}

Figure 26. Water-table altitudes and contributing areas for a well pumped at 0.5 million gallons per day located, $A, 200 ; B, 600$; and, $C, 1,400 \mathrm{ft}$ from a source of induced infiltration. 


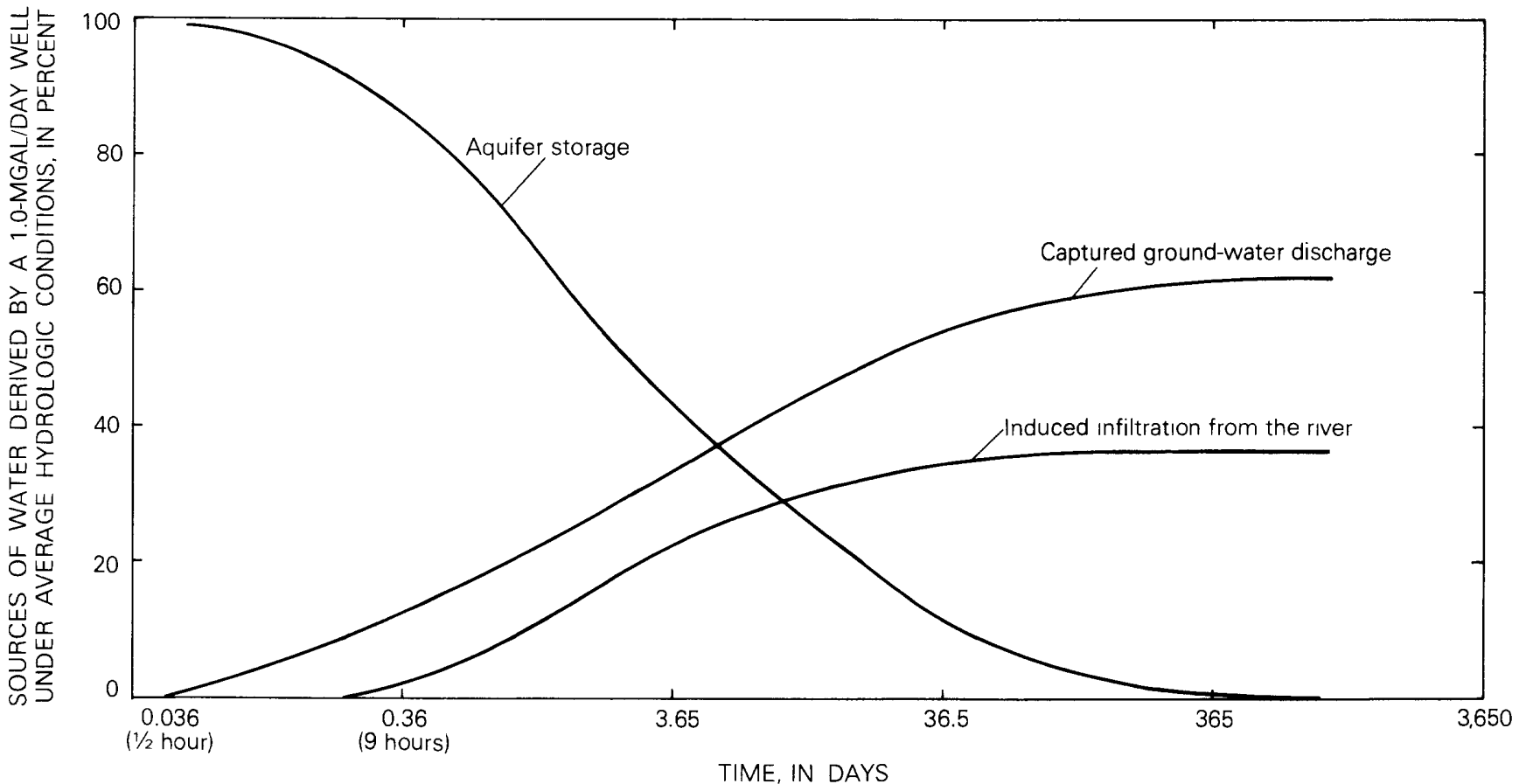

Figure 27. Sources of water pumped by a well, under average conditions, as a function of time.

remaining layers are smaller in areal extent to more accurately simulate the geometry of the hypothetical aquifer. Horizontal, $200 \mathrm{ft}$, and vertical, $20 \mathrm{ft}$, grid spacing is uniform for each layer.

The top layer of the model is assumed to have unconfined conditions. Transmissivity is computed as a function of saturated thickness and hydraulic conductivity after each model iteration. Nodes, where the leaky streambed and recharge from areas underlain by till adjacent to the aquifer are simulated, are located in the top layer. Boundary conditions used in the top layer of the three-dimensional model are the same as those described for the twodimensional simulation. The bottom four layers of the model are simulated as having no-flow conditions along each side but can interact with layers immediately above or below.

Horizontal aquifer hydraulic conductivity $\left(K_{\mathrm{h}}\right)$ is the same as used in the two-dimensional model. Vertical hydraulic conductivity $\left(K_{\mathrm{v}}\right)$ was modeled as 0.1 of the horizontal values. Recharge to the model was applied uniformly on the top layer at the same rate used in the two-dimensional simulation ( $2 \mathrm{ft} / \mathrm{yr}$ ). The resulting nonpumping steady-state water-table configuration that was computed by using the three-dimensional model is shown in figure 29. The steady-state water budget and water-table configuration computed by using the three-dimensional model are essentially the same as those computed by using the two-dimensional model.

Vertical Anisotropy and Well Penetration. - Wells completed in stratified-drift aquifers, screened over a small portion of available saturated thickness, are referred to as having partial penetration. Partial penetration creates vertical flow components, in an aquifer near the pumping well, that cannot be accurately simulated by using a twodimensional flow model. The three-dimensional model allows analysis of the effects of partial penetration by providing the capability to simulate the well screen in a specific vertical location (layer) within an aquifer.

The three-dimensional model also allows investigation of the effects of vertical variations in aquifer hydraulic conductivity. The alternate layering of coarse and fine materials within stratified-drift deposits creates a situation in which vertical hydraulic conductivity is less than horizontal hydraulic conductivity. The ratio of horizontal to vertical hydraulic conductivity in stratified drift is typically 10:1 but may be as high as 100:1 or 1,000:1 (Rosenshein and others, 1968; Franke and Getzen, 1975; Larson and others, 1975; and Guswa and LeBlanc, 1985).

A series of simulations was run in which well penetration and the ratio of horizontal to vertical hydraulic conductivity were varied. The hydraulic conductivity ratio was varied from 1:1 to $100: 1$, and the well was located in either the top two layers or the bottom two layers of the model. As with the two-dimensional modeling, simulations were run to steady state so that the maximum effects of pumping could be observed. At steady state, the sources of water to the well are induced infiltration from the river and captured ground-water discharge that originates as areal recharge from precipitation on the aquifer or as runoff from upland till areas adjacent to the aquifer. Variations in the 


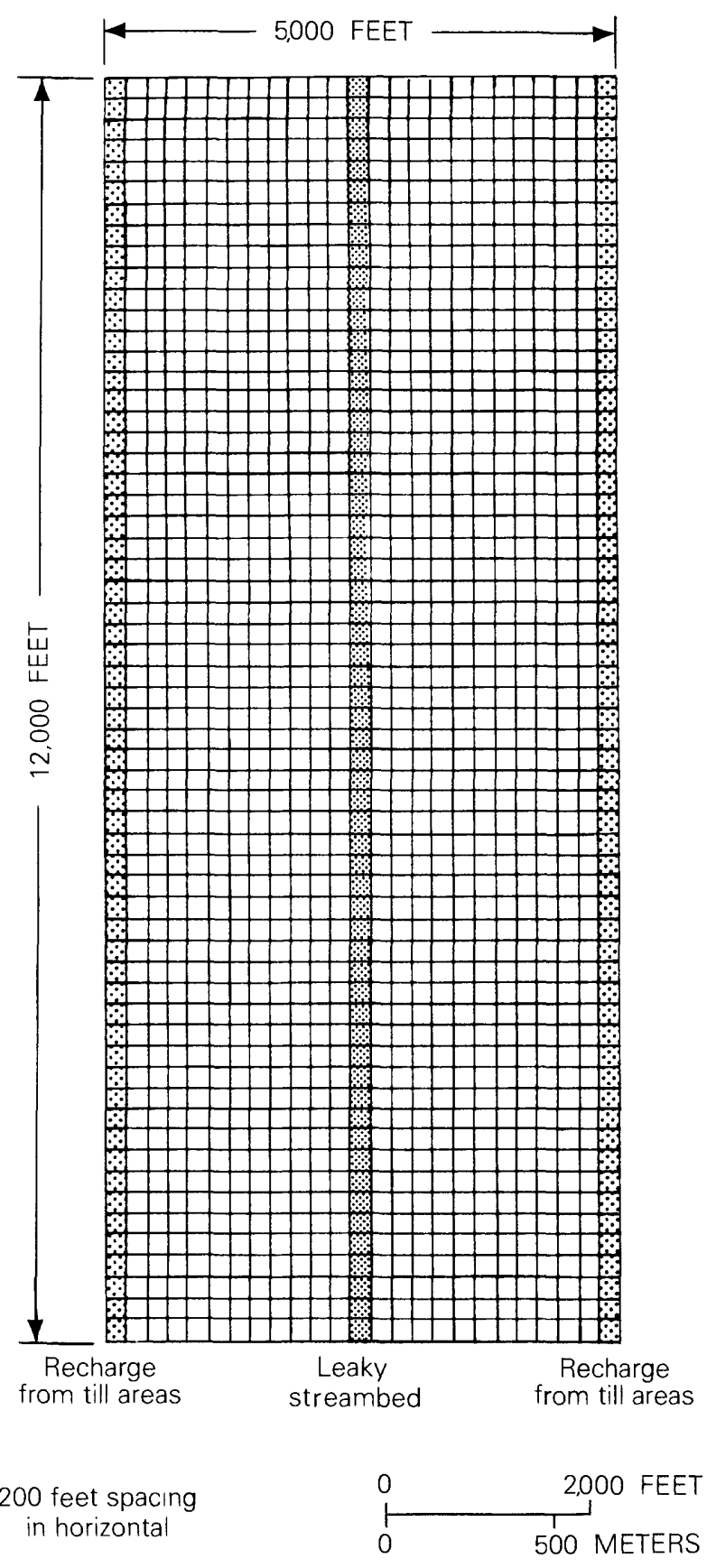

A. Plan view.

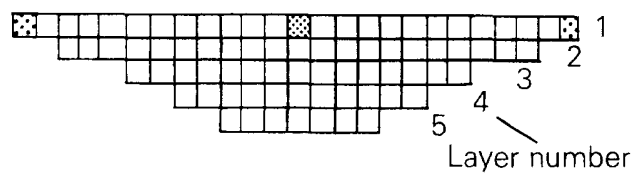

20 feet uniform spacing in vertical

VERTICAL EXAGGERATION $\times 10$

B. Cross-sectional view.
Table 4. Total contributing area size as a function of well penetration and $K_{\mathrm{h}} / K_{\mathrm{v}}$

[Contributing areas $\left(\mathrm{mi}^{2}\right)$ in stratified drift and till upland; $K_{\mathrm{b}}$, horizontal hydraulic conductivity; $K_{\mathrm{v}}$, vertical hydraulic conductivity]

\begin{tabular}{ccc}
\hline$K_{\mathrm{h}} / K_{\mathrm{v}}$ & Well in layers 1,2 & Well in layers 4,5 \\
\hline $1: 1$ & 11.13 & 1.13 \\
$10: 1$ & 1.27 & 1.39 \\
$100: 1$ & 1.40 & 1.72 \\
\hline
\end{tabular}

${ }^{1}$ Same rate as computed by using the two-dimensional model for average conditions.

size of the contributing area for a well pumping $1.0 \mathrm{Mgal} / \mathrm{d}$ that result from changes in the ratio of $K_{\mathrm{h}} / K_{\mathrm{v}}$ and well penetration are summarized in table 4 .

When $K_{\mathrm{h}} / K_{\mathrm{v}}$ is $1: 1$, the vertical location of the well screen in the aquifer has a negligible effect on the size of the contributing area and the amount of induced infiltration caused by the well. In addition, the contributing area is the same size as that computed by using the two-dimensional model because the two-dimensional model simulations assumed a $K_{\mathrm{h}} / K_{\mathrm{v}}$ of 1:1, and factors that control streambed leakage are identical in both models.

When $K_{\mathrm{h}} / K_{\mathrm{v}}$ is increased from $1: 1$ to $10: 1$, the contributing area for a pumping well increases in size because the increased resistance to vertical flow allows less induced recharge from the river. As a result, the contributing area grows to make up for this loss in recharge. For a well screen located in the bottom of the aquifer, the contributing area increased from 1.13 to $1.39 \mathrm{mi}^{2}$ when $K_{\mathrm{h}} / K_{\mathrm{v}}$ increased from $1: 1$ to $10: 1$.

The vertical position of the well screen in the aquifer has a slight effect on the size of the contributing area when $K_{\mathrm{h}} / K_{\mathrm{v}}$ is $10: 1$. Under these conditions, a well screen located in the top $40 \mathrm{ft}$ of the aquifer has a contributing area of 1.27 $\mathrm{mi}^{2}$. When the screen is moved to the bottom $40 \mathrm{ft}$ of the aquifer, the contributing area encompasses $1.39 \mathrm{mi}^{2}$.

When $K_{\mathrm{h}} / K_{\mathrm{v}}$ is increased from $10: 1$ to $100: 1$, the contributing areas grow even larger. The areas increased in size by $0.13 \mathrm{mi}^{2}$ for a well located in the top $40 \mathrm{ft}$ of the aquifer and by $0.33 \mathrm{mi}^{2}$ for a well located in the bottom 40 $\mathrm{ft}$ of the aquifer. A well located in the bottom $40 \mathrm{ft}$ of the aquifer receives less than 2 percent of pumped water from induced infiltration when $K_{\mathrm{h}} / K_{\mathrm{v}}$ is $100: 1$. Therefore, essentially all of the water pumped by the well is made up of captured ground-water discharge (fig. 30).

The three-dimensional model simulations point out several interesting facts about determination of the contributing area of a well in the hypothetical aquifer:

1. The two- and three-dimensional models produced identical results only when $K_{\mathrm{h}} / K_{\mathrm{v}}$ was $1: 1$ in the threedimensional model. For $K_{\mathrm{h}} / K_{\mathrm{v}}>1$, the threedimensional model estimates a larger contributing area

4 Figure 28. Finite-difference grid used for the threedimensional numerical-model analysis. 


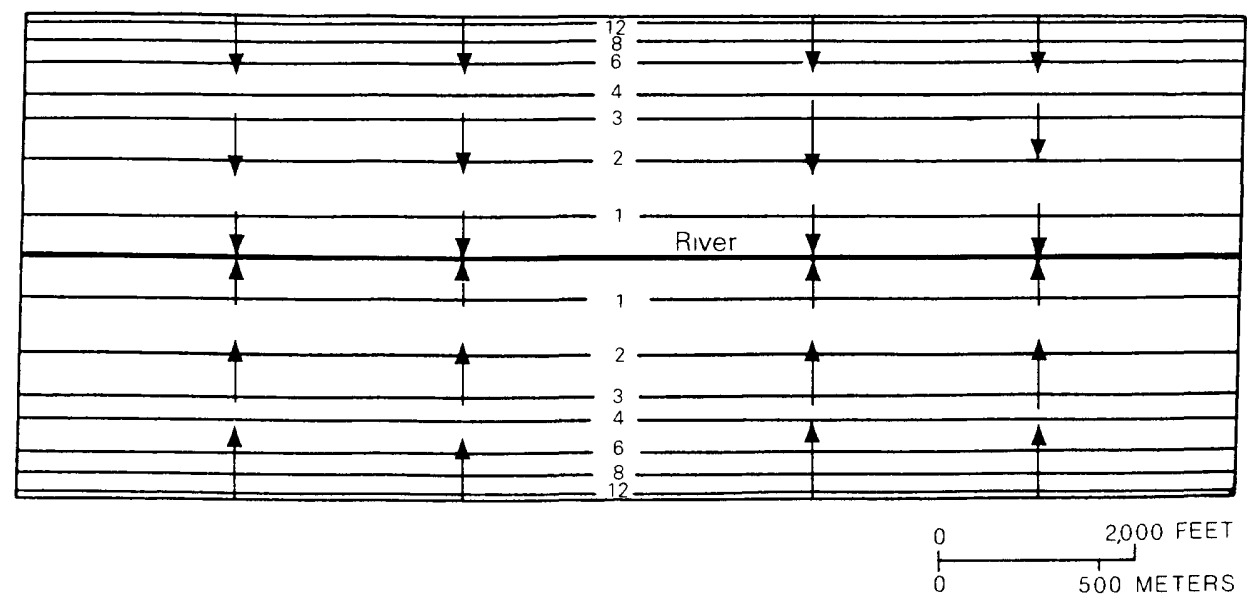

EXPLANATION

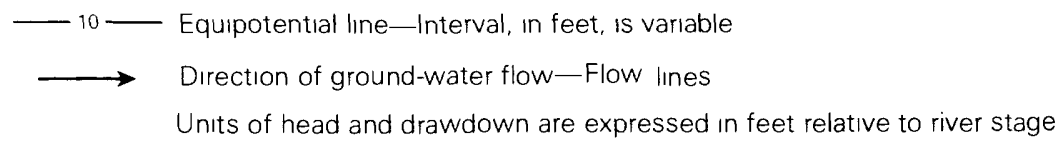

Figure 29. Steady-state nonpumping water-table altitudes computed by using the three-dimensional numerical model.

for the well than the two-dimensional model because the three-dimensional model accounts for a decrease in the amount of induced infiltration caused by increased vertical resistance to flow in the aquifer.

2. The vertical location of the well in the three-dimensional model affected the rate of induced infiltration and hence the size of the contributing area for the well. When $K_{\mathrm{h}} / K_{\mathrm{v}}$ is $1: 1$ or $10: 1$, this effect is negligible, but when $K_{\mathrm{h}} / K_{\mathrm{v}}$ is $100: 1$, a well screened in the bottom layers of the aquifer has a larger contributing area then a well screened in the top layers.

3. Two-dimensional numerical analysis will underestimate the size of the contributing area of a well in a stratified-drift aquifer in which $K_{\mathrm{h}} / K_{\mathrm{v}}>1$ unless vertical components of flow in the aquifer are accounted for by using the two-dimensional model. Equation 1 can be modified to account for vertical components of flow under the leaky riverbed (see Reilly and others, 1983 , p. 23-26).

4. The three-dimensional model allows estimation of the three-dimensional zone of contribution (fig. 30). However, for the relatively thin aquifer (100 ft or less) considered in these simulations, the zone of contribution extends throughout the entire thickness of the aquifer, and the enveloping surface of the contributing area is close to vertical everywhere.

\section{Summary of the Effects of Selected Hydrogeologic Factors}

All of the hydrogeologic factors that were tested had some effect on the size and shape of the contributing area for a well in the hypothetical aquifer. The magnitudes of these effects are summarized in table 5 for the steady-state two-dimensional numerical-model analyses. The initial set of hydrologic conditions, which formed the basis for subsequent comparisons, was described in the section A Hypothetical Glacial-Drift, River-Valley Aquifer System. The pumping rate of a well has a direct effect on the size and shape of the contributing area and on the sources of water pumped from the well. In the steady-state modeling simulations, sources of water for a well included captured ground-water discharge (that originated as recharge from areal precipitation on the stratified-drift aquifer and as recharge from areas underlain by till adjacent to the aquifer) and induced infiltration from the river. If all other factors were constant, an increase in well discharge increased both the size of the contributing area and the amount of water obtained from induced infiltration. Depending on the contrast in the quality of ground water and surface water at a given site, well-discharge rate could be adjusted to influence the quality of pumped water.

When well discharge is held constant and recharge from areal precipitation on the aquifer and runoff originat- 
Table 5. Summary of the effects of variations in selected geohydrologic factors on the size of the contributing area of a well in a hypothetical aquifer

$[-$, no data $]$

\begin{tabular}{|c|c|c|c|c|c|c|c|c|c|c|c|c|}
\hline \multirow{2}{*}{ Geohydrologic conditions } & \multicolumn{12}{|c|}{ Simulation number } \\
\hline & 1 & 2 & 3 & 4 & 5 & 6 & 7 & 8 & 9 & 10 & 11 & 12 \\
\hline \multicolumn{13}{|l|}{$\begin{array}{l}\text { Well discharge, in million gallons } \\
\text { per day: }\end{array}$} \\
\hline 0.5 . & & $\mathrm{X}$ & & & & & & & & & $\mathrm{X}$ & $\mathrm{X}$ \\
\hline $1.0 \ldots \ldots \ldots \ldots \ldots \ldots \ldots \ldots$ & $\mathrm{X}$ & & $\mathrm{X}$ & $\mathrm{X}$ & $\mathrm{X}$ & $\mathrm{X}$ & $\mathrm{X}$ & $\mathrm{X}$ & $\mathrm{X}$ & $\mathrm{X}$ & & \\
\hline \multicolumn{13}{|l|}{$\begin{array}{l}\text { Aquifer recharge (average is } 24 \\
\text { inches per year): }\end{array}$} \\
\hline $0.5 \times$ average $\ldots \ldots \ldots$ & & & & & $\mathrm{X}$ & & & & & & & \\
\hline Average $\ldots \ldots \ldots \ldots \ldots \ldots$ & $\mathbf{X}$ & $\mathrm{X}$ & $\mathrm{X}$ & & & & $\mathbf{X}$ & $\mathrm{X}$ & $X$ & $\mathrm{X}$ & $\mathrm{X}$ & $\mathrm{X}$ \\
\hline $1.5 \times$ average $\ldots \ldots \ldots \ldots \ldots$ & & & & & & $\mathrm{X}$ & & & & & & \\
\hline After 6 months of no recharge & & & & $\mathrm{X}$ & & & & & & & & \\
\hline \multicolumn{13}{|l|}{$\begin{array}{l}\text { Ratio of streambed thickness to } \\
\text { streambed permeability }\left(k^{\prime} / b^{\prime}\right) \text { : }\end{array}$} \\
\hline $0.1 \ldots \ldots \ldots \ldots \ldots \ldots \ldots$ & & & & & & & $\mathrm{X}$ & & & & & \\
\hline $1.0, \ldots \ldots \ldots \ldots \ldots \ldots \ldots$ & $\mathrm{X}$ & $\mathrm{X}$ & $\mathrm{X}$ & & $\mathrm{X}$ & $X$ & & & $X$ & $X$ & $\mathrm{X}$ & $X$ \\
\hline $10.0 \ldots \ldots \ldots \ldots \ldots \ldots \ldots$ & & & & & & & & $\mathrm{X}$ & & & & \\
\hline $0.0 \ldots \ldots \ldots \ldots \ldots \ldots \ldots$ & & & & $\mathrm{X}^{1}$ & & & & & & & & \\
\hline \multicolumn{13}{|l|}{$\begin{array}{l}\text { Aquifer hydraulic conductivity (aver- } \\
\text { age is } 10 \text { to } 100 \mathrm{ft} \text { per day): }\end{array}$} \\
\hline $0.3 \times$ average $\ldots \ldots \ldots \ldots \ldots$ & & & & & & & & & $\mathrm{X}$ & & & \\
\hline Average $\ldots \ldots \ldots \ldots \ldots \ldots$ & $\mathrm{X}$ & $\mathrm{X}$ & $\mathrm{X}$ & $\mathrm{X}$ & $\mathrm{X}$ & $\mathrm{X}$ & $\mathrm{X}$ & $\mathrm{X}$ & & & $\mathrm{X}$ & $\mathrm{X}$ \\
\hline $3.0 \times$ average $\ldots \ldots \ldots \ldots \ldots$ & & & & & & & & & & $\mathrm{X}$ & & \\
\hline \multicolumn{13}{|l|}{ Distance to well from river: } \\
\hline $200 \mathrm{ft} \ldots \ldots \ldots \ldots \ldots \ldots$ & $\mathrm{X}$ & $\mathrm{X}$ & $\mathrm{X}$ & $\mathrm{X}$ & $\mathrm{X}$ & $\mathrm{X}$ & $\mathrm{X}$ & $\mathrm{X}$ & $\mathrm{X}$ & $\mathrm{X}$ & $\mathbf{X}$ & \\
\hline $1,400 \mathrm{ft} \ldots \ldots \ldots \ldots \ldots \ldots \ldots \ldots$ & & & & & & & & & & & & $\mathrm{X}$ \\
\hline \multicolumn{13}{|l|}{ Aquifer specific yield: } \\
\hline $\begin{array}{l}\text { Steady state, } 0 \text { percent } \ldots \ldots \ldots \ldots \\
\text { Transient, } 20 \text { percent } \ldots \ldots \ldots \ldots\end{array}$ & $\mathrm{X}$ & $\mathrm{X}$ & $\mathrm{X}$ & $\mathrm{X}$ & $\mathrm{X}$ & $X$ & $X$ & $\mathrm{X}$ & $\mathrm{X}$ & $\mathrm{X}$ & $\mathrm{X}$ & $X$ \\
\hline \multicolumn{13}{|c|}{ Results } \\
\hline \multicolumn{13}{|l|}{$\begin{array}{l}\text { Size of contributing area in square } \\
\text { miles: }\end{array}$} \\
\hline Total area $\ldots \ldots \ldots \ldots \ldots$ & 1.13 & 0.73 & 1.57 & ${ }^{2} 1.70$ & 1.66 & 0.90 & 1.77 & 0.89 & 1.01 & 1.33 & 0.98 & 0.98 \\
\hline Area underlain by till.... & .78 & .53 & 1.13 & - & 1.19 & .67 & 1.29 & .63 & .75 & .96 & .74 & .74 \\
\hline Area underlain by drift ....... & .35 & .20 & .44 & 1.70 & .47 & .23 & .48 & .26 & .26 & .37 & .24 & .24 \\
\hline \multicolumn{13}{|l|}{$\begin{array}{l}\text { Sources of water to well by } \\
\text { percent volume: } \\
\text { Induced infiltration from }\end{array}$} \\
\hline river. . . . . . . . . . . . & 35 & 16 & 56 & 0 & 56 & 26 & 8 & 45 & 44 & 26 & 0 & 0 \\
\hline Area recharge to areas & & & & & & & & & & & & \\
\hline underlain by drift $\ldots \ldots \ldots \ldots 4$ & & 47 & 25 & 0 & 25 & 42 & 51 & 33 & 30 & 42 & 55 & 53 \\
\hline Runoff from areas underlain by & & & & & & & & & & & & \\
\hline till adjacent to the aquifer $\ldots .2$ & & 37 & 19 & 0 & 19 & 32 & 41 & 22 & 26 & 32 & 45 & 47 \\
\hline Aquifer storage $\ldots \ldots \ldots \ldots \ldots$ & 0 & 0 & 0 & 100 & 0 & 0 & 0 & 0 & 0 & 0 & 0 & 0 \\
\hline
\end{tabular}

${ }^{1}$ River assumed to be dry.

${ }^{2}$ Contributing areas in till not determined.

ing in areas underlain by till adjacent to the aquifer are reduced, induced infiltration and the contributing area of a well increase to make up for the decreased availability of water.

When recharge from all sources stops entirely and the river goes dry, the contributing area grows continuously to capture enough water to balance the pumping rate. During this period, water pumped by the well is derived entirely from storage in the aquifer. The size of the contributing area under these conditions is controlled by the specific yield of the aquifer and the duration of the pumping. If this situation persists long enough, the contributing area for a well could be the entire aquifer area.
The model simulations show that, in a typical stratified-drift, river-valley aquifer, induced infiltration from the river provides significant quantities of water to wells. For average equilibrium conditions in the hypothetical aquifer, with the well located $200 \mathrm{ft}$ from the river, induced infiltration supplies 35 percent of pumped water. Under low recharge conditions, induced infiltration constitutes more than 50 percent of pumped water. Any factor that increases the amount of induced infiltration obtained by a well will decrease the size of the contributing area and vice versa. This result was evident in simulations in which streambed permeability was varied and the well was moved further from the river in either a horizontal (two- 


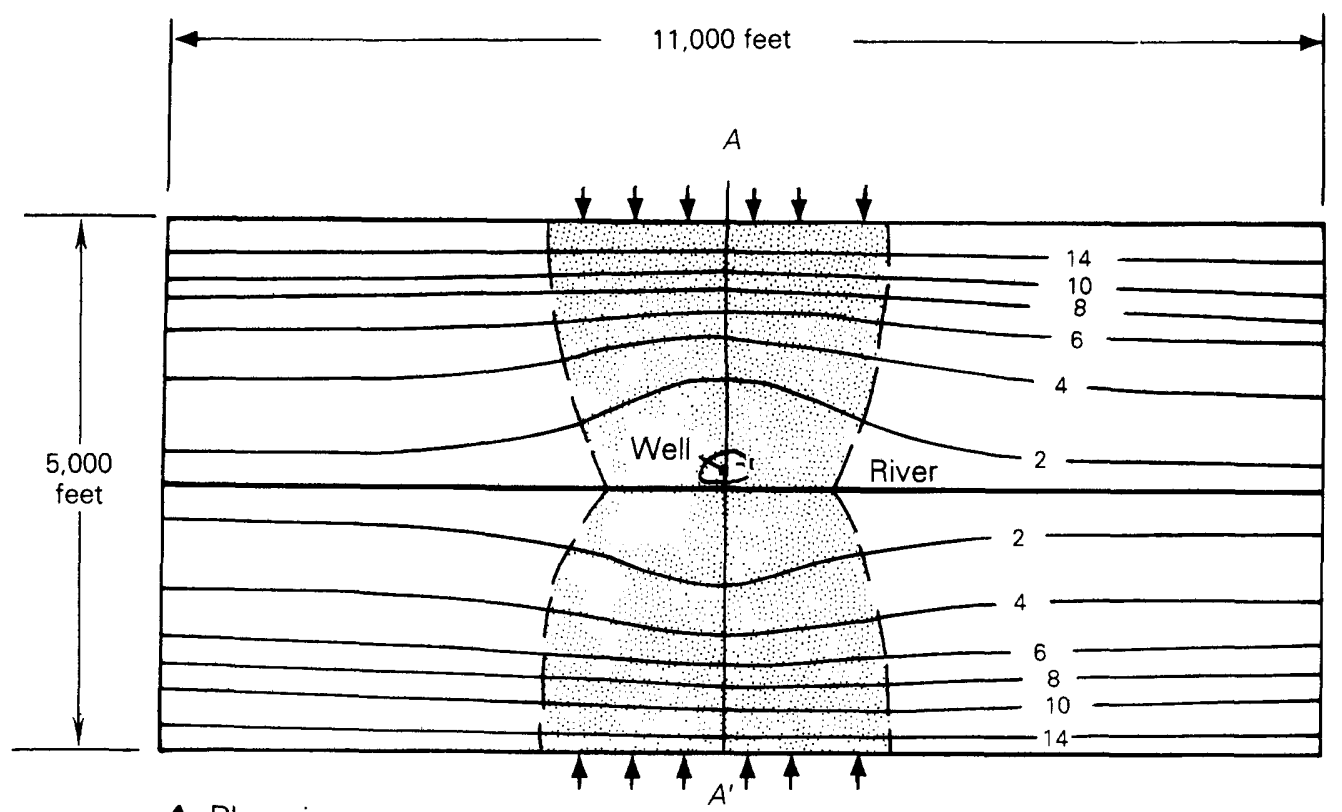

A. Plan view.

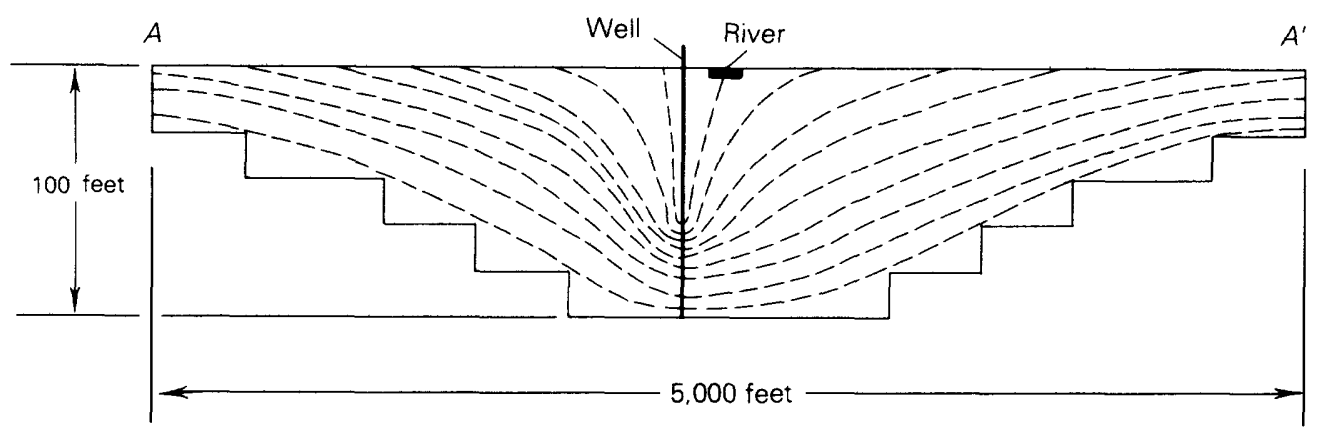

B. Cross-sectional view.

VERTICAL EXAGGERATION $\times 11$

\section{EXPLANATION}

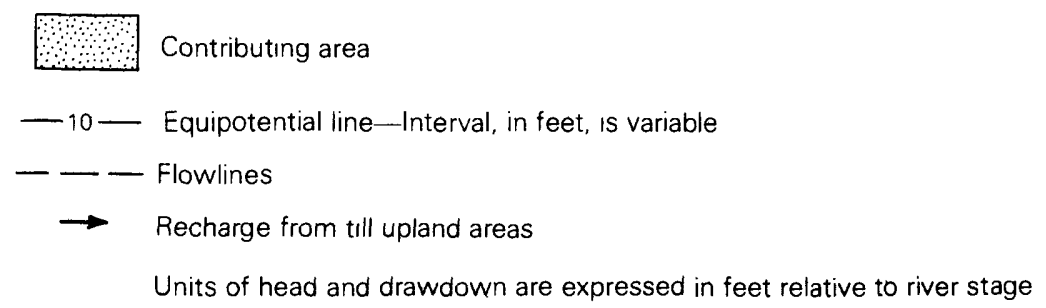

Figure 30. Zone of contribution for a well, pumped at 1.0 million gallons per day, as determined by using the three-dimensional numerical model.

dimensional numerical simulations) or vertical (threedimensional numerical simulations) direction.

Variations in the horizontal hydraulic conductivity of the aquifer affected the size of the contributing area of a pumped well located $200 \mathrm{ft}$ from the river such that an increase in hydraulic conductivity slightly increased the size of the contributing area. An increase in hydraulic conductivity decreases the amount of induced infiltration obtained by the well.
When the ratio between horizontal and vertical permeability $\left(K_{\mathrm{h}} / K_{\mathrm{v}}\right)$ was increased (three-dimensional simulations), the amount of induced infiltration obtained by the well decreased, and the size of the contributing area increased. This result was most evident when the well was screened in the bottom $40 \mathrm{ft}$ of the aquifer. When the well was screened in the top $40 \mathrm{ft}$ of the aquifer, variation in $K_{\mathrm{h}} / K_{\mathrm{v}}$ had less affect on induced infiltration and size of the contributing area. 
Certainly, other factors affecting the area that contributes flow to a well have not been tested in these model simulations. For example, under drought conditions, the size of a contributing area depends on the specific yield of the aquifer. Also, if pumping wells are introduced near an existing well, the flow patterns could change and affect the size and shape of a contributing area. The synergistic effect of varying several factors at once, such as a simultaneous decrease in recharge and an increase in pumping rate, could lead to much larger contributing areas than those determined by varying geohydrologic factors one at a time, as was done in these simulations.

Some of the factors affecting contributing areas that can be controlled are pumping rate, the distance of a well from a possible source of induced infiltration such as a river (Weeks and Appel, 1984), the degree of well penetration, and the proximity of wells to each other. Factors beyond control are natural variation in recharge from precipitation, length and severity of drought conditions, degree of interconnection between surface water and ground water, and aquifer permeability. Because of the number of factors involved and an imperfect understanding of how these factors can vary, the determination of contributing area is only an estimate.

\section{COMPARISON OF METHODS AND GUIDELINES FOR ESTIMATING CONTRIBUTING AREAS}

Analytical-mathematical model analysis, twodimensional numerical simulation, and three-dimensional numerical simulation methods for estimating the contributing area of a well in a stratified-drift, river-valley aquifer are based on hydraulic analysis of ground-water flow in the vicinity of a well or well field. The methods represent a range of complexity in terms of speed of application and ability to handle the geohydrologic conditions encountered in the field. No method should be applied universally for estimating the contributing area of a well in stratified-drift, river-valley aquifers. The essential geohydrologic features at a given site must be incorporated into the technique used to estimate a contributing area. A simple flowchart is presented to serve as a guide for selecting a method to estimate contributing areas in a stratified-drift, river-valley aquifer (fig. 31).

Analytical techniques have the advantage of being easy to apply in terms of time, necessary data, and computational complexity. Analytical methods can provide answers in a matter of hours by using only pencil, paper, and calculator. The serious disadvantage of analytical methods is the gross simplification of field conditions required. Analytical model simulation of a partially penetrating surface-water body is limited to the use of a line source boundary. Although corrections can be made for the effective distance to the boundary so that aquifer response is reasonably estimated on the well side of the river (Rorabaugh, 1956), aquifer response beneath and beyond the streambed cannot be correctly simulated (Walton and Ackroyd, 1966). The result is a contributing area limited to the well side of a river. This result was clearly illustrated when an analytical model containing a line source river boundary was used to estimate the contributing area of a well in the hypothetical aquifer (fig. 13).

Another serious limitation in the use of analytical methods is the assumption that aquifer response is linear (confined). In typical, thin, river-valley aquifer systems, the combined stress of low recharge rates and high well yield can cause drawdowns that are large compared with total saturated aquifer thickness. Under these conditions, the assumption of linear aquifer response is violated, and superposition may yield incorrect results. Analytical methods are most applicable where key simplifying assumptions are met or closely approached by field conditions. Such situations can exist in thick aquifers in which wells are located far from the effects of aquifer boundaries, such as in a wide valley or broad outwash plain. If aquifer boundaries are close to the pumping well and are simple, such as for a fully penetrating river, an analytical method might provide useful results.

If constraints - time or money-force the use of an analytical method, the analysis can be designed to provide a conservative estimate (largest contributing area) by using very conservative values for the data required in the analysis. Analytical methods might provide a worthwhile preliminary analysis that could be followed by more complex modeling. The basic data needed for analytical model analysis of a contributing area are as follows:

1. A water-table map that shows water-table altitudes in the aquifer before pumping begins will form the basis for the analytical method of analysis. Drawdowns determined by using the analytical model are subtracted (superimposed) from the prepumping water-table map to determine the contributing area for a well. If the largest possible contributing area is to be estimated, the prepumping water-table map should reflect extreme low-water conditions.

2. Boundary conditions in an analytical model will be idealized as straight lines that have either a no-flow impermeable barrier or a constant head.

3. Well-field design criteria that describe the pumping rate, pumping schedule, and well construction are needed for model analysis. As illustrated in model simulations, the maximum expected pumping rate must be known to determine the largest possible contributing area of a well.

4. Aquifer hydraulic properties for an analytical model should include average aquifer transmissivity and specific yield. Sensitivity testing of a range of possible 


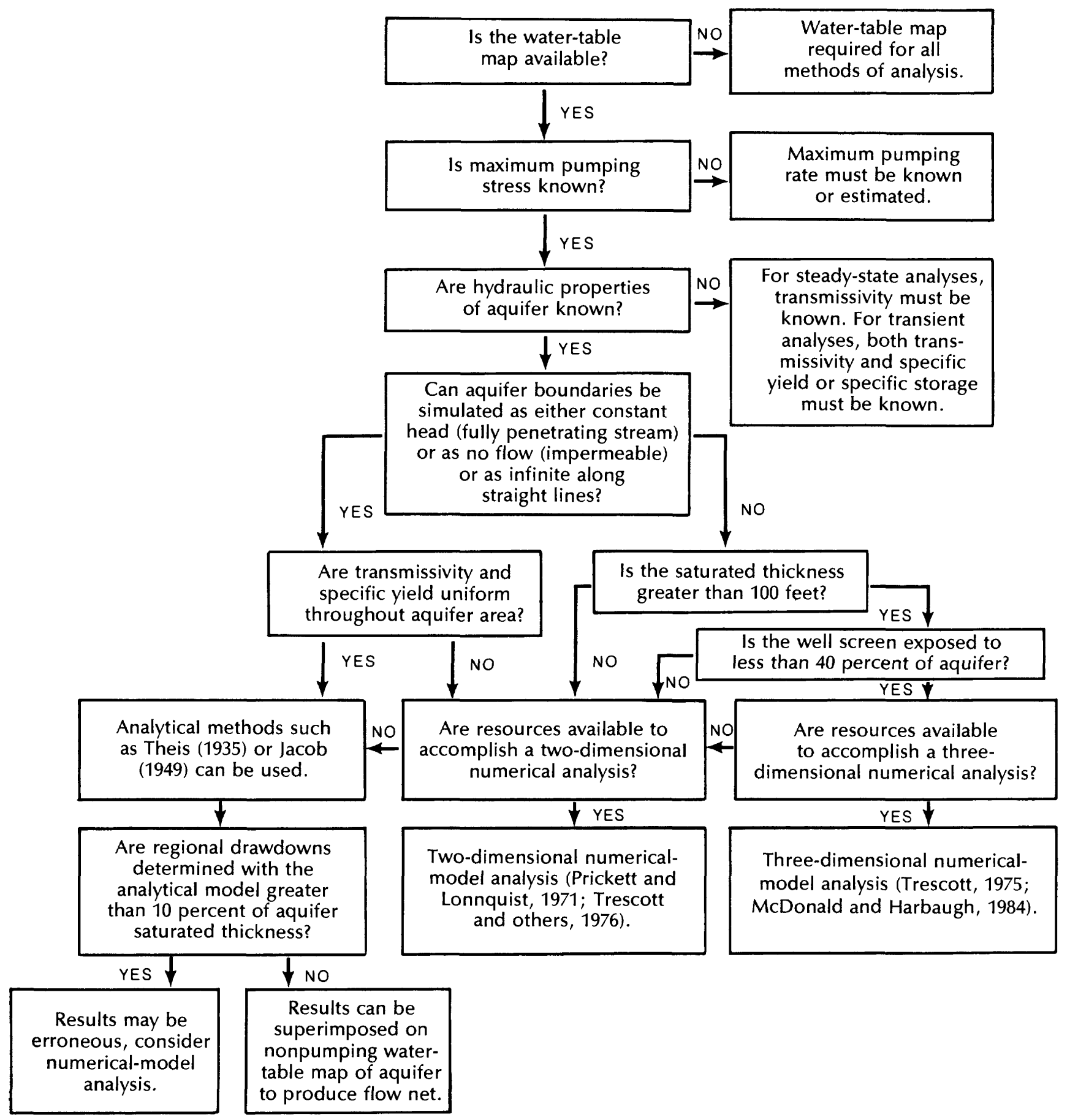

Figure 31. Guide for selecting a hydraulic method of analysis to estimate the contributing area of a well in an unconfined stratified-drift, river-valley aquifer.

values will show how these parameters affect the size of a contributing area for a specific field problem.

Two dimensional numerical models overcome many of the limitations of analytical methods and therefore are the most widely used tool for aquifer analysis. Complex boundary conditions, nonlinear aquifer response, and heterogene ity can be simulated in a more realistic manner. A numerical-model analysis takes more time than an analytical model analysis and requires a digital computer. In addition, numerical models require more data for construction and calibration because aquifer hydraulic properties, recharge, and discharge must be specified for each block in the grid network (fig. 14). 
The decision to use a two-dimensional numerical model for estimating the contributing area of a well will be based on many factors, such as time constraints, personnel, hardware and software availability, degree of accuracy required, and data availability. If all necessary items are available, a two-dimensional numerical-model analysis might require anywhere from a few days to a few months. The minimum hardware requirement is a microcomputer that has sufficient memory to execute a standard groundwater-flow model code that allows simulation of the essential hydrologic features of the system under consideration.

The hydrologic data necessary for a two-dimensional numerical-model simulation (in approximate order of importance) are as follows:

1. A water-table map is probably the most important data element for construction and calibration of any numerical-flow model. The water-table map shows the upper limit of an unconfined aquifer, directions of ground-water flow, and recharge and discharge areas. A map of average water-table altitudes is usually sufficient, but maps that show extreme conditions aid model calibration.

2. Boundary conditions that specify the location and hydrologic conditions along model boundaries can significantly affect model results. For a typical unconfined river-valley aquifer, the bottom of the aquifer and the lateral boundaries must be defined. Hydrologic conditions along each of these boundaries must be specified. Boundary conditions that could be used in a numerical simulation are specified head or specified flux or could be more specialized conditions such as a headdependent flux across a leaky streambed or a tillstratified-drift interface.

3. Well-field design criteria that describe the locations and maximum expected yield of a well or well field are essential for estimating the contributing area for the well. Locations and discharge of nearby wells that can affect flow patterns and contributing areas should be incorporated in model simulation.

4. Aquifer hydraulic properties such as hydraulic conductivity and specific yield (for transient analyses) must be assigned to each block in the numerical-model grid. Usually these values are determined at a few discrete locations and interpolated over the rest of the area or are estimated during model calibration. For contributing area determination in the hypothetical aquifer, variations in hydraulic conductivity had less effect on model results than other parameters tested.

5. Recharge from areal precipitation on stratified drift and runoff from adjacent areas underlain by till are given a low rank in relative importance because they can usually be estimated from available data. The most conservative (largest contributing area) estimate for the aquifer resulted from a 180 -day period in which all recharge had ceased.
A comparison of results obtained from the analytical model that used a line source river boundary (fig. $13 C$ ) with results from a two-dimensional numerical simulation in which the river was simulated as a partially penetrating boundary (fig. 17B) shows how choice of method can affect the size and shape of a contributing area estimated for the same geohydrologic conditions. The numerical model more realistically simulates the partially penetrating streambed by allowing drawdowns and the contributing area to extend beneath and beyond the stream. The numerical approach provides the most widely applicable method for aquiferwide analysis of ground-water flow and estimation of contributing areas in an unconfined stratified-drift, rivervalley aquifer.

Three-dimensional numerical-model analysis is the most complex method of those investigated because additional data are necessary for model construction and calibration. The amount of data required for the threedimensional analysis (of the hypothetical aquifer) was approximately equal to the number of layers in the model multiplied by the amount of data used in the twodimensional analysis. Because of the additional data required for three-dimensional simulation, more computer storage is also necessary.

The advantages of using a three-dimensional model are the abilities to simulate vertical components of flow in the aquifer and to simulate confining layers. The layering in a three-dimensional model also allows more detailed descriptions of variations in aquifer properties to be made. The result of an analysis using a three-dimensional numerical model is a volumetric representation of the zone of contribution of a pumping well (fig. 30).

A comparison of results obtained from the two- and three-dimensional models shows differences in the computed rates of induced infiltration from the river and in the sizes of estimated contributing areas. When $K_{\mathrm{h}} / K_{\mathrm{v}}$ is equal to 1 , results obtained by using the two- and threedimensional models are very similar. When $K_{\mathrm{h}} / K_{\mathrm{v}}$ is greater than 1 , the three-dimensional model estimates a larger contributing area for a well than the two-dimensional simulation. Three-dimensional model analyses allow simulation of vertical resistance to flow in the aquifer beneath the partially penetrating streambed and results in less induced infiltration and a larger contributing area for a given pumping condition.

The most widely applicable and most practical method of those investigated for estimating the contributing area of a well in a glacial-drift, river-valley aquifer is the two-dimensional numerical-model analysis. Because most of these aquifers are relatively thin (100 ft or less), the two-dimensional model analysis is usually adequate. If there is a high degree of vertical anisotropy and the well partially penetrates the aquifer, the two-dimensional model may underestimate a contributing area. However, this condition could be approximated in a two-dimensional 
model by employing the proper modification (Reilly and others, 1983).

Exact determination of the contributing area of a pumping well is a difficult task. There is, in reality, no such thing as fixed contributing area for a pumping well. In nature, the contributing area is constantly changing in response to changing hydrologic conditions, such as variation in aquifer recharge, variation in pumping rate, and change in the stage of the surface-water body that acts as a source of induced infiltration.

Despite the uncertainty involved in determining the contributing area for a pumping well, a carefully executed hydraulic analysis will provide valuable information. Clearly, the contributing area for a well in a typical stratified-drift, river-valley aquifer is much more extensive than the simple circular areas that are currently used to protect ground-water quality. The most conservative contributing area (largest expected area) can be estimated by using the most reasonably conservative values for geohydrologic parameters that are included in the method of analysis.

\section{SUMMARY AND CONCLUSIONS}

The major sources of water for wells in unconfined, stratified-drift, river-valley aquifers include storage, capture of ambient ground-water flow, and induced infiltration of surface water. Ambient ground-water flow captured by a well can originate as precipitation that recharges the aquifer directly through infiltration or as runoff in upland areas adjacent to the aquifer that recharges aquifer boundaries.

The contributing area of a well is not the same as the area of influence of a well. The area of influence is the land area that has the same horizontal extent as the cone of depression caused by the well. Recharge that enters the aquifer through the area of influence of a well will not necessarily travel to the well, and recharge that enters the aquifer outside the area of influence may travel to the well.

The contributing area of a well is the land area that has the same horizontal extent as that part of an aquifer from which flow is diverted to the well. Recharge that enters an aquifer through the contributing area of a well will eventually be discharged by the pumped well. The extent of an area of influence is limited only by the physical boundaries of an aquifer, whereas the extent of a contributing area is limited to the area around a well in which captured recharge equals well discharge.

Factors that can influence the size and shape of the contributing area of a well in stratified-drift, river-valley aquifers include (but are not limited to) the duration of pumping, well discharge rate, aquifer recharge rate, proximity of the well to sources of induced infiltration, degree of well penetration in the aquifer, aquifer hydraulic conductivity, ratio of horizontal to vertical hydraulic conductivity, and specific yield of the aquifer. The size and shape of the estimated contributing area of a well also depends on the assumptions implicit in the method of analysis, such as the way in which boundaries are simulated and the model's ability to vary hydraulic properties spatially.

To evaluate the applicability of methods for estimating contributing areas and to determine the effects of variations of selected geohydrologic factors on the sizes and shapes of contributing areas, simulations of a pumping well in a hypothetical aquifer were performed. The hypothetical system was designed to represent a major class of aquifers-namely, unconfined, glacial-drift, river-valley aquifers-common in New England. Most high-yield supply wells in the region are located in this type of setting.

The methods used to estimate contributing areas included analytical, two-dimensional numerical, and threedimensional numerical models. The analytical methods lack flexibility for simulating geohydrologic factors that affect the contributing area of a well in a typical glacial-drift, river-valley aquifer. They are subject also to the limitations involved in the use of superposition. The analytical methods are best suited to situations where important simplifying assumptions closely approximate field conditions. The most widely applicable method of those tested was the twodimensional model analysis. This method provides a compromise between the analytical and three-dimensional numerical analyses in terms of speed of application, applicability to field conditions typical of glacial-drift aquifers, and data requirements.

The three-dimensional model analysis for estimating contributing areas is the most complete but complicated and time-consuming technique of those investigated. In situations where the required data are available for model construction and calibration, this technique can be used to provide the most complete analysis. Three-dimensional analysis is applicable particularly to very thick aquifers in which vertical components of flow can affect well response. Vertical flow conditions can be caused by a combination of partial well penetration and aquifer anisotropy.

Because of the large number of factors that can affect contributing areas and an imperfect understanding of how these factors can vary, the estimation of contributing areas is an approximation at best. If sources of induced infiltration, such as streams, go dry and recharge ceases for extended periods, the size of a contributing area can include the entire extent of an aquifer.

The estimation of contributing areas should incorporate the most conservative values for geohydrologic factors that control aquifer response so that the maximum probable area is predicted. However, protecting only contributing areas will not ensure that the water obtained will not be polluted by induced infiltration of contaminated surface water. If the quality of stream flow entering the contributing area of a well is unsuitable for human consumption, the quality of water pumped from the well may also be unacceptable. 
Estimation of contributing areas is an imperfect science because we have a limited understanding of the effects of geohydrologic factors and we cannot predict future hydrologic conditions. Despite these problems, the use of reasonable methods of analysis can provide important information about the sizes and shapes of areas that contribute flow to wells.

All of the methods used to estimate contributing areas in this study involve hydraulic analysis of ground-water flow, whereby solute-transport phenomena have been neglected. The assumption inherent in this approach is that contaminants will move with the ground water and will not be subject to diffusion and dispersion. An area for continued study is to use solute-transport models to investigate the fate of specific contaminants in the idealized aquifer. Other areas for continued research include delineation of contributing areas for wells located in fractured rock aquifers and investigation of the effects of multiple wells and cyclic pumping on the size and shape of contributing areas.

\section{REFERENCES CITED}

Bear, Jacob, 1979, Hydraulics of groundwater: New York, McGraw-Hill, 569 p.

Bennett, G.D., 1976, Introduction to ground-water hydraulics, a programmed text for self-instruction: U.S. Geological Survey Techniques of Water-Resources Investigations, book 3, chap. B2, 172 p. [Reprinted 1978.]

Brown, R.H., 1963, The cone of depression and the area of diversion around a discharging well in an infinite strip aquifer subject to uniform recharge: U.S. Geological Survey WaterSupply Paper 1545-C, p. C69-C85.

Cervione, M.A., Jr., Mazzaferro, D.L., and Melvin, R.L., 1972, Water resources inventory of Connecticut, pt. 6, upper Housatonic River basin: Connecticut Water Resources Bulletin $21,84 \mathrm{p}$.

DaCosta, J.A., and Bennett, R.R., 1960, The pattern of flow in the vicinity of a recharging and discharging pair of wells in an aquifer having areal parallel flow: International Association of Scientific Hydrology, General Assembly of Helinski, Publication No. 52, p. 524-536.

Dickerman, D.C., and Ozbilgin, M.M., 1985, Hydrology, water quality, and ground-water development alternatives in the Beaver-Pasquiset ground-water reservoir, Rhode Island: U.S. Geological Survey Water-Resources Investigations Report 85-4190, 104 p.

Ferris, J.G., Knowles, D.B., Brown, R.H., and Stallman, R.W., 1962, Theory of aquifer tests: U.S. Geological Survey Water-Supply Paper 1536-E, p. 69-174.

Franke, O.L., and Getzen, R.T., 1975, Evaluation of hydrologic properties of the Long Island ground-water reservoir using cross-sectional electric-analog models: U.S. Geological Survey Open-File Report 75-679, 80 p.

Freeze, R.A., and Cherry, J.A., 1979, Groundwater: Englewood Cliffs, New Jersey, Prentice-Hall, Inc., 604 p.

Guswa, J.H., and LeBlanc, D.R., 1985, Digital models of ground-water flow in the Cape Cod aquifer system, Massa- chusetts: U.S. Geological Survey Water-Supply Paper 2209, $112 \mathrm{p}$.

Haeni, F.P., 1978, Computer modeling of ground-water availability in the Pootatuck River Valley, Newton, Connecticut: U.S. Geological Survey Water-Resources Investigations Report 78-77, $64 \mathrm{p}$.

Hantush, M.S., 1965, Wells near streams with semipervious beds: Journal of Geophysical Research, v. 70, no. 12, p. 2829-2838.

Heath, R.C., 1983, Basic ground-water hydrology: U.S. Geological Survey Water-Supply Paper 2220, 84 p.

Horsley, S.W., 1983, Delineating zones of contribution of public supply wells to protect ground water, in Proceedings of the National Water Well Association Eastern Regional Conference, Ground-Water Management, Orlando, Fla.

Jacob, C.E., 1949, Flow of ground water, in Rouse, Hunter, ed., Engineering hydraulics: John Wiley, chap. 5, p. 321-378.

Keely, J.F., 1984, Optimizing pumping strategies for contaminant studies and remedial actions: Ground Water Monitoring Review, v. 4, no. 3, p. 63-74.

Keely, J.F., and Tsang, C.F., 1983, Velocity plots and capture zone of pumping centers for ground-water investigations: Ground Water, v. 21, no. 6, p. 701-714.

Kirkham, Don, 1949, Flow of ponded water into drain tubes in soil overlying an impervious layer: Transactions of the American Geophysical Union, v. 30, no. 3, p. 369-385.

1951, Seepage into drain tubes in stratified soil: Transactions of the American Geophysical Union, v. 32, no. 3, p. $422-442$.

Larson, S.P., McBride, M.S., and Wolf, R.J., 1975, Digital models of a glacial-outwash aquifer in the Pearl-Sallie Lakes area, west-central Minnesota: U.S. Geological Survey WaterResources Investigations Report 40-75, 39 p.

Lohman, S.W., 1972, Ground-water hydraulics: U.S. Geological Survey Professional Paper 708, 70 p. [Reprinted 1975 and 1979.]

Lyford, F.P., Dysart, J.E., Randall, A.D., and Kontis, A.L., 1984, Glacial aquifer systems in the northeastern United States; a study plan: U.S. Geological Survey Open-File Report 83-928, 33 p.

MacNish, R.D., and Randall, A.D., 1982, Stratified-drift aquifers in the Susquehanna River basin, New York: New York State Department of Environmental Conservation Bulletin 75, 68 p.

MacNish, R.D., Randall, A.D., and Ku, H.F.H., 1969, Water availability in urban areas of the Susquehanna River basin, a preliminary appraisal: New York State Conservation Department Water Resources Commission Report of Investigation RI-7, 24 p.

Mazzaferro, D.L., 1980, Ground-water availability and water quality in Farmington, Connecticut: U.S. Geological Survey Water-Resources Investigations Open-File Report 80-751, $57 \mathrm{p}$.

- 1989, Estimation of the recharge area of a pumped, stratified-drift aquifer in Connecticut by simulation modeling: U.S. Geological Survey Water-Resources Investigations Report 87-4124, 100 p.

Mazzaferro, D.L., Handman, E.H., and Thomas, M.P., 1979 , Water resources inventory of Connecticut, pt. 8, Quinnipiac 
River basin: Connecticut Water Resources Bulletin No. 27, $88 \mathrm{p}$.

McDonald, M.G., and Harbaugh, A.W., 1984, A modular threedimensional finite-difference ground-water flow model: U.S. Geological Survey Open-File Report 83-875, 528 p.

Meinzer, O.E., 1923, Outline of ground-water hydrology, with definitions: U.S. Geological Survey Water-Supply Paper 494, $71 \mathrm{p}$.

Mercer, J.W., and Faust, C.R., 1981, Ground-water modeling: National Water Well Association, Columbus, Ohio, 60 p.

Morrissey, D.J., 1983, Hydrology of the Little Androscoggin River valley aquifer, Oxford County, Maine: U.S. Geological Survey Water-Resources Investigations Report 83-4018, $79 \mathrm{p}$.

Olimpio, J.C., and de Lima, Virginia, 1984, Ground-water resources of the Mattapoisett River valley, Plymouth County, Massachusetts: U.S. Geological Survey Water-Resources Investigations Report 84-4043, 88 p.

Prickett, T.A., and Lonnquist, C.G., 1971, Selected digital computer techniques for groundwater resources evaluation: Illinois State Water Survey Bulletin 55, 62 p.

Randall, A.D., 1978, Infiltration from tributary streams in the Susquehanna River basin, New York: U.S. Geological Survey Journal of Research, v. 6, no. 3, p. 285-297.

Reilly, T.E., Buxton, H.T., Franke, O.L., and Wait, R.L., 1983, Digital model study of the effects of sanitary sewers on ground-water levels and streams in Nassau and Suffolk Counties, New York, pt. 1, Geohydrology, modeling strategy, and regional evaluation: U.S. Geological Survey WaterResources Investigations Report 82-4045, 45 p.

Reilly, T.E., Franke, O.L., and Bennett, G.D., 1984, The principle of superposition and its application in ground-water hydraulics: U.S. Geological Survey Open-File Report $84-459,36 \mathrm{p}$.

Remson, Irwin, Hornberger, G.M., and Molz, F.J., 1971, Numerical methods in subsurface hydrology: New York, John Wiley and Sons, Inc., 389 p.

Rorabaugh, M.I., 1956, Ground water in northeastern Louisville, Kentucky, with reference to induced infiltration: U.S. Geological Survey Water-Supply Paper 1360-B, p. 101-169.

Rosenshein, J.S., Gonthier, J.B., and Allen, W.B., 1968, Hydrologic characteristics and sustained yield of principal groundwater units, Potowomut-Wickford area, Rhode Island: U.S. Geological Survey Water-Supply Paper 1775, 38 p.

Theis, C.V., 1938, The significance and nature of the cone of depression in ground-water bodies: Economic Geology, v. 33 , no. 8 , p. 889-902.
-1940 , The source of water derived from wells; essential factors controlling the response of an aquifer to development: Civil Engineering, May, p. 277-280.

Theis, C.V., and Conover, C.S., 1963, Chart for determination of the percentage of pumped water being derived from a stream or drain: U.S. Geological Survey Water-Supply Paper 1545-C, p. C106-C109.

Todd, D.K., 1980, Groundwater hydrology: New York, John Wiley and Sons, Inc., $535 \mathrm{p}$.

Torak, L.J., 1982, Modifications and corrections to the finitedifference model for simulation of three-dimensional groundwater flow: U.S. Geological Survey Water-Resources Investigations Report 82-4025, 30 p.

Trescott, P.C., 1975, Documentation of finite-difference model for simulation of three-dimensional ground-water flow: U.S. Geological Survey Open-File Report 75-438, 32 p.

Trescott, P.C., and Larson, S.P., 1976, Documentation of finitedifference model for simulation of three-dimensional groundwater flow: U.S. Geological Survey Open-File Report 76-591, 21 p. [Supplement.]

Trescott, P.C., Pinder, G.F., and Larson, S.P., 1976, Finitedifference model for aquifer simulation in two dimensions with results of numerical experiments: U.S. Geological Survey Techniques of Water-Resources Investigations, book 7 , chap. C1, 116 p.

U.S. Geological Survey, 1985, National water summary, 1984, hydrologic events, selected water-quality trends, and groundwater resources: U.S. Geological Survey Water-Supply Paper $2275,467 \mathrm{p}$.

Walton, W.C., and Ackroyd, E.A., 1966, Effects of induced infiltration on water levels in wells during aquifer tests: Minnesota Water Resources Research Center, Bulletin 2, $43 \mathrm{p}$.

Wang, H.F., and Anderson, M.P., 1982, Introduction to groundwater modeling: San Francisco, California, W.H. Freeman and Co., $237 \mathrm{p}$.

Weeks, E.P., and Appel, C.A., 1984, Optimum location of a well near a stream, in Groundwater hydraulics: American Geophysical Union Water Resources Monograph 9, p. 4-28.

Wilson, J.L., 1981, Analytical methods in groundwater hydrology: Boston Society of Civil Engineers geotechnical lecture series for $1981,116 \mathrm{p}$.

Wilson, J.L., and Townley, L.R., 1980, Description of and user's manual for a finite element aquifer flow model AQUIFEM-1: Cambridge, Massachusetts, Massachusetts Institute of Technology, Ralph M. Parson Laboratory, report no. 252. 


\section{SELECTED SERIES OF U.S. GEOLOGICAL SURVEY PUBLICATIONS}

\section{Periodicals}

Earthquakes \& Volcanoes (issued bimonthly).

Preliminary Determination of Epicenters (issued monthly).

\section{Technical Books and Reports}

Professional Papers are mainly comprehensive scientific reports of wide and lasting interest and importance to professional scientists and engineers. Included are reports on the results of resource studies and of topographic, hydrologic, and geologic investigations. They also include collections of related papers addressing different aspects of a single scientific topic.

Bulletins contain significant data and interpretations that are of lasting scientific interest but are generally more limited in scope or geographic coverage than Professional Papers. They include the results of resource studies and of geologic and topographic investigations, as well as collections of short papers related to a specific topic.

Water-Supply Papers are comprehensive reports that present significant interpretive results of hydrologic investigations of wide interest to professional geologists, hydrologists, and engineers. The series covers investigations in all phases of hydrology, including hydrogeology, availability of water, quality of water, and use of water.

Circulars present administrative information or important scientific information of wide popular interest in a format designed for distribution at no cost to the public. Information is usually of short-term interest.

Water-Resources Investigations Reports are papers of an interpretive nature made available to the public outside the formal USGS publications series. Copies are reproduced on request unlike formal USGS publications, and they are also available for public inspection at depositories indicated in USGS catalogs.

Open-File Reports include unpublished manuscript reports, maps, and other material that are made available for public consultation at depositories. They are a nonpermanent form of publication that may be cited in other publications as sources of information.

\section{Maps}

Geologic Quadrangle Maps are multicolor geologic maps on topographic bases in 7.5- or 15-minute quadrangle formats (scales mainly $1: 24,000$ or $1: 62,500$ ) showing bedrock, surficial, or engineering geology. Maps generally include brief texts; some maps include structure and columnar sections only.

Geophysical Investigations Maps are on topographic or planimetric bases at various scales; they show results of surveys using geophysical techniques, such as gravity, magnetic, seismic, or radioactivity, which reflect subsurface structures that are of economic or geologic significance. Many maps include correlations with the geology.

Miscellaneous Investigations Series Maps are on planimetric or topographic bases of regular and irregular areas at various scales; they present a wide variety of format and subject matter. The series also includes 7.5-minute quadrangle photogeologic maps on planimetric bases that show geology as interpreted from aerial photographs. Series also includes maps of Mars and the Moon.
Coal Investigations Maps are geologic maps on topographic or planimetric bases at various scales showing bedrock or surficial geology, stratigraphy, and structural relations in certain coal-resource areas.

Oil and Gas Investigations Charts show stratigraphic information for certain oil and gas fields and other areas having petroleum potential.

Miscellaneous Field Studies Maps are multicolor or blackand-white maps on topographic or planimetric bases on quadrangle or irregular areas at various scales. Pre-1971 maps show bedrock geology in relation to specific mining or mineral-deposit problems; post-1971 maps are primarily black-and-white maps on various subjects such as environmental studies or wilderness mineral investigations.

Hydrologic Investigations Atlases are multicolored or blackand-white maps on topographic or planimetric bases presenting a wide range of geohydrologic data of both regular and irregular areas; principal scale is 1:24,000, and regional studies are at 1:250,000 scale or smaller.

\section{Catalogs}

Permanent catalogs, as well as some others, giving comprehensive listings of U.S. Geological Survey publications are available under the conditions indicated below from the U.S. Geological Survey, Books and Open-File Reports Section, Federal Center, Box 25425. Denver, CO 80225. (See latest Price and Availability List.)

"Publications of the Geological Survey, 1879-1961" may be purchased by mail and over the counter in paperback book form and as a set of microfiche.

"Publications of the Geological Survey, 1962-1970" may be purchased by mail and over the counter in paperback book form and as a set of microfiche.

"Publications of the U.S. Geological Survey, 1971-1981" may be purchased by mail and over the counter in paperback book form (two volumes, publications listing and index) and as a set of microfiche.

Supplements for 1982, 1983, 1984, 1985, 1986, and for subsequent years since the last permanent catalog may be purchased by mail and over the counter in paperback book form.

State catalogs, "List of U.S. Geological Survey Geologic and Water-Supply Reports and Maps For (State)," may be purchased by mail and over the counter in paperback booklet form only.

"Price and Availability List of U.S. Geological Survey Publications," issued annually, is available free of charge in paperback booklet form only.

Selected copies of a monthly catalog "New Publications of the U.S. Geological Survey" are available free of charge by mail or may be obtained over the counter in paperback booklet form only. Those wishing a free subscription to the monthly catalog "New Publications of the U.S. Geological Survey" should write to the U.S. Geological Survey, 582 National Center, Reston, VA 22092.

Note.-Prices of Government publications listed in older catalogs, announcements, and publications may be incorrect. Therefore, the prices charged may differ from the prices in catalogs, announcements, and publications. 